C/ORNL/93-0191

Metals and Ceramics Division

Crada Final Report

for CRADA ORNL 93-0191

\title{
ENERGY EFFICIENCY STUDY OF SINGLE-WIDE MANUFACTURED HOMES
}

David W. Yarbrough and Gregory J. Andrews

Tennessee Technological University

Department of Chemical Engineering

Center for Manufacturing Research

Cookeville, Tennessee 38505 USA

Therese K. Stovall

Oak Ridge National Laboratory

Oak Ridge, Tennessee 37831 USA

\section{Ty Kelly}

Clayton Homes

Maynardville, Tennessee 37804 USA

Date Published- December 1999

\author{
Prepared by the \\ Oak Ridge National Laboratory \\ Oak Ridge, Tennessee 37831-6092 \\ Managed by \\ LOCKHEED MARTIN ENERGY RESEARCH CORP. \\ for the \\ U.S. DEPARTMENT OF ENERGY \\ under contract DE-AC05-96OR22464 \\ APPROVED FOR PUBLIC RELEASE \\ DISTRIBUTION IS UNLIMITED
}





\section{EXECUTIVE SUMMARY}

This report covers a project that was carried out from 1994 to 1998. The project included laboratory characterization of the insulations used in the manufactured home test units, instrumentation of two full-size single-wide manufactured homes, and measurement of ceiling heat fluxes, roof-cavity temperatures, and electric power use. One of the full-size units that was studied contained the manufacturer's standard insulation package while the second unit contained an upgraded insulation package. A roof cavity test facility was constructed to test the use of a combination of vacuum insulation panels and loose-fill rock wool to insulate manufactured home roof cavities.

The performance of the installed roof cavity insulation compared favorably with that predicted by laboratory measurements. The standard unit had a time-average roof cavity insulation $\mathrm{R}$-value of $17\left(\mathrm{R}_{\mathrm{SI}^{-}}-3.0\right)$ versus the claimed value of $\mathrm{R}-14\left(\mathrm{R}_{\mathrm{SI}}-2.4\right)$ while the upgraded unit showed $\mathrm{R}-23.5\left(\mathrm{R}_{\mathrm{SI}^{-}}-4.1\right)$ versus the claimed value of $\mathrm{R}-21\left(\mathrm{R}_{\mathrm{SI}}-3.6\right)$. The upgraded unit had nominal R-21 ( $\left.\mathrm{R}_{\mathrm{SI}^{-}}-3.6\right)$ on the floor of the cavity and $\mathrm{R}-7\left(\mathrm{R}_{\mathrm{SI}^{-}}-1.2\right)$ below the roof. The nominal or laboratory values are for an average temperature of $75^{\circ} \mathrm{F}$ $\left(24^{\circ} \mathrm{C}\right)$ while the actual performance values reflect temperatures that vary over a relatively wide range.

The upgraded unit used less energy over the period of the project than the standard unit. The ratio of electric power use for the standard unit over the upgraded unit was 1.3. This difference cannot be explained totally by the insulation in the roof cavity since analysis showed that only about one-fourth of the electric power used for heating and cooling was due to heat loss or gain across the ceiling. Differences in air exchange rates and equipment efficiency also contribute to the units' energy use.

Computer simulations show that a significant savings in ceiling heat loss or gain would result from adding thermal resistance in the roof-cavity truss region. The thermal break in the truss region could be improved, for example, by using nominal $2 \times 4 \mathrm{~s}$ in place of $2 \times 2 \mathrm{~s}$ for the ceiling joists or by covering the tops of the joists with insulation.

A radiation control coating, white in color with a solar reflectance of 0.86 , was 
applied to the exterior roof surfaces of both units in August of 1996. Comparison of data collected before and after the coating was applied showed decreased attic temperatures for both the standard and upgraded unit. Energy savings are highly dependent on geographical location so computer simulations using DOE 2.1E were carried out for a set of cities across the United States. These computer simulations for nine cities were completed for a single-wide manufactured home configuration with $\mathrm{R}-14\left(\mathrm{R}_{\mathrm{SI}}-2.4\right)$ roof cavity insulation, the standard package. Annual electric power savings ranged from 894 $\mathrm{kWh}$ for $346 \mathrm{ft}^{2}\left(32.2 \mathrm{~m}^{2}\right)$ of roof in Rapid City to $2119 \mathrm{kWh}$ for the same roof area in Los Angeles. In every location simulated there was a heating season penalty that partly off-set the reductions in air-conditioning load.

The field performance of vacuum insulation panels was compared with laboratory performance. The comparison was favorable for panels installed away from the edge of the roof cavity. Two of the three panels installed along the edge of the roof cavity exhibited performance well below the predicted level. One panel was observed to be soft, indicating a loss of vacuum. Panels can be installed between trusses and covered with conventional loose-fill. The panels will perform as expected if protected from puncture. 
TABLE OF CONTENTS

\section{Page}

EXECUTIVE SUMMARY $\ldots \ldots \ldots \ldots \ldots \ldots \ldots \ldots \ldots \ldots \ldots \ldots$ iii

LIST OF FIGURES $\ldots \ldots \ldots \ldots \ldots \ldots \ldots \ldots \ldots \ldots \ldots \ldots \ldots \ldots \ldots \ldots$ vii

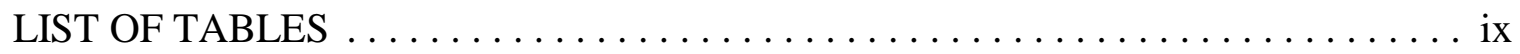

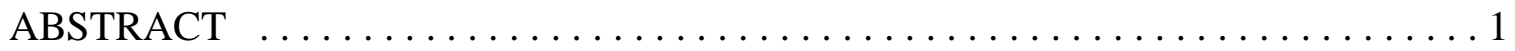

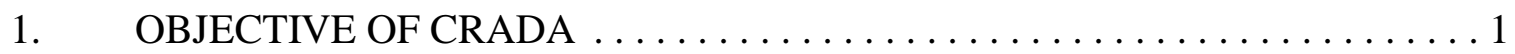

2. BENEFITS OF CRADA TO DOE $\ldots \ldots \ldots \ldots \ldots \ldots \ldots \ldots \ldots \ldots \ldots$

3. TECHNICAL DISCUSSION OF RESULTS $\ldots \ldots \ldots \ldots \ldots \ldots \ldots \ldots$

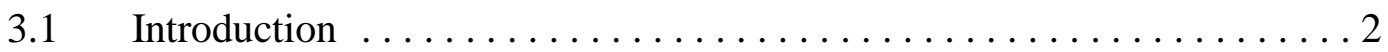

3.2 Description of Test Units and Instrumentation $\ldots \ldots \ldots \ldots \ldots \ldots 4$

3.2.1 Full-Size Manufactured Homes ..................... 4

3.2.2 Roof Cavity Test Unit ....................... 7

3.2.3 Heat Flux Transducers and Thermocouples ............. 10

3.2.4 On-Site Weather Data Collection $\ldots \ldots \ldots \ldots \ldots \ldots \ldots \ldots 11$

3.3. Heat Flow in the Full-Size Manufactured Homes $\ldots \ldots \ldots \ldots \ldots 13$

3.3.1 Laboratory Measurements . ................... 13

3.3.2 Field Data Analysis - Ceiling Heat Flux Through the Insulation 17

3.3.3 Field Data Analysis - Total Energy Consumption ........... 24

3.3.4 Computational Fluid Dynamics Models $\ldots \ldots \ldots \ldots \ldots . \ldots 30$

3.3.5 Effect of Air Infiltration on Energy Consumption . . . . . . . . . 39

3.3.6 Total Energy Use for Heating and Cooling ................ 44

3.3.7 Effect of Radiation Control Coating Applied to Roof ......... 49

3.4. Roof Cavity Heat Flow with Vacuum Insulation Panels . . . . . . . . . . 57

3.4.1 Laboratory Measurements . . . . . . . . . . . . . . . . . . 57

3.4.2 Field Data Analysis $\ldots \ldots \ldots \ldots \ldots \ldots \ldots \ldots$

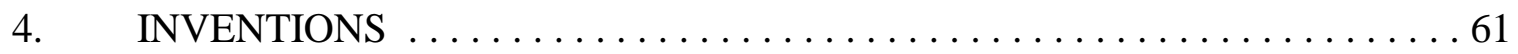

5. COMMERCIALIZATION POSSIBILITIES $\ldots \ldots \ldots \ldots \ldots \ldots \ldots \ldots \ldots \ldots$

6. PLANS FOR FUTURE COLLABORATIONS $\ldots \ldots \ldots \ldots \ldots \ldots \ldots \ldots \ldots$

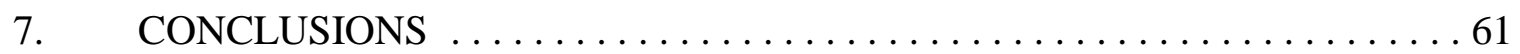

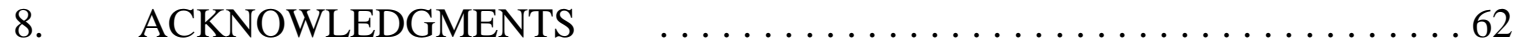

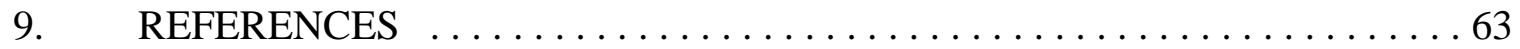




\section{LIST OF FIGURES}

1. End/side view of manufactured homes used in this project. ........... 5

2. Heat flux transducer and thermocouple locations in the full-size manufactured homes. ................................. 6

3. Photograph of roof test facility. $\ldots \ldots \ldots \ldots \ldots \ldots \ldots \ldots \ldots \ldots \ldots$

4. Photograph of roof test facility with one test section open. ............ 9

5. Vacuum panel and heat flux transducer positions in roof test facility

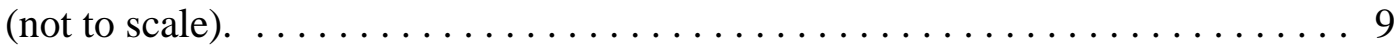

6. Comparison of field-measured roof cavity insulation thermal resistance to laboratory-measured data for the standard manufactured home unit. . . . . . . 19

7. Comparison of field-measured roof cavity insulation thermal resistance to laboratory-measured data for the upgraded manufactured home unit (batt installed against the roof not included here $). \ldots \ldots \ldots \ldots \ldots \ldots \ldots \ldots \ldots \ldots$

8. Ratio of edge to center heat flux transducer energy gain/loss. . . . . . . . 23

9. Fraction of total energy input into test homes that is lost or gained through the ceiling - 1995-1996 data. . . . . . . . . . . . . . . . . . . . . . . 29

10. Grid used to calculate heat and mass flows for the standard insulation attic space.......................................... 31

11. Grid used to calculate heat and mass flows for the upgraded insulation attic

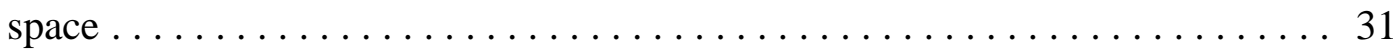

12. Air temperatures measured during January, 1997 for time periods used to benchmark two-dimensional computational fluid dynamics model. . . . . . . 32

13. Overall attic space R-values (including indoor and outdoor surface air resistances) calculated using measured heat fluxes and outdoor temperatures for comparison

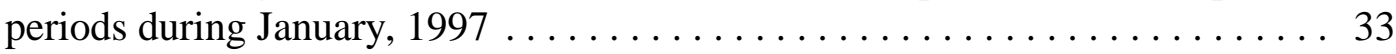

14. Air flow patterns predicted by computational model in standard insulation attic space. 
15. Air flow patterns predicted by computational model in upgraded insulation attic space. ......................................... 35

16. Temperature distributions predicted by computational model in standard insulation attic space. ................................... 36

17. Temperature distributions predicted by computational model in upgraded

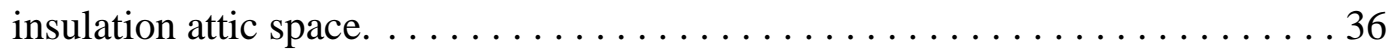

18. Geometry used in three-dimensional computational models of attic space with and without air gaps parallel to each joist. . . . . . . . . . . . . . . . 38

19. Grid used to calculate heat and mass flows for the three-dimensional model of the

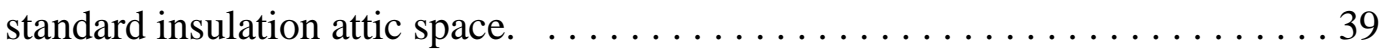

20. Grid slice parallel to the attic centerline, perpendicular to the wood attic joist, from the three-dimensional model of the standard insulation attic space. . . . . 4 40

21. Monthly percentage of air infiltration energy loss for standard and upgraded manufactured home units. . . . . . . . . . . . . . . . . . . . 43

22. Comparison of outdoor air temperatures for similar summer days. ........53

23. Comparison of incident solar radiation for similar summer days. ......... 53

24. Comparison of temperature differences between the attic ridge and the outdoor air for similar summer days (set 2) before and after application of reflective roof

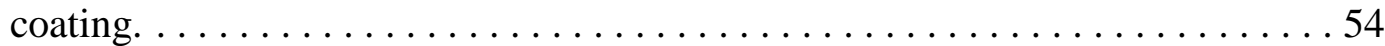

25. Comparison of temperature differences between the attic ridge and the outdoor air for similar summer days (set 4) before and after application of reflective roof

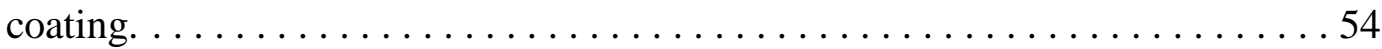




\section{List of Tables}

1. Thermocouple Locations in the Full-size Manufactured Home Attics . . . . . . 7

2. Heat Flux Transducer and Vacuum Panel Locations in the Roof Test Facility . . 10

3. Calibration Factors for Heat Flux Transducers Installed in the Roof Cavities of the Manufactured Home Units and the Roof Test Facility ............. 11

4. Apparent Thermal Conductivity Data for Fiberglass Batt Insulation as a Function

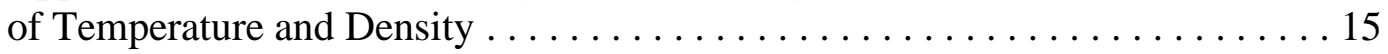

5. Comparison of Apparent Thermal Conductivity Measured to that Predicted by Eq. 3 for Fiberglass Batt Insulation as a Function of Temperature and Density . . . 16

6. Fiberglass Batt Field Thickness Measurements [in. (m)] . . . . . . . . . 19

7. Variation of Thermal Resistance (R-Value) of Roof Cavity Insulation on a

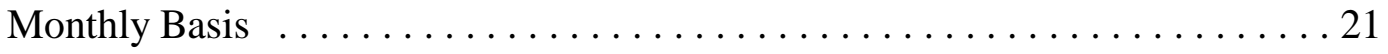

8. Overall Attic Floor Thermal Resistances of Standard and Upgraded Roof Assemblies with 1.5 in. and 3.5 in. Wooden Joists in Parallel Heat Flow - 19951996 Data . . . . . . . . . . . . . . . . . . . . . . . 26

9. Fraction of Total Energy Input into Test Homes that is Lost or Gained through the Ceiling - 1995-1996 Data . . . . . . . . . . . . . . . . . . . . . . . . 29

10. Values of Parameters Used in Computational Fluid Dynamics Model . . . . . . 32

11. Effect of Varying Heat Transfer Parameters on Heat Flow Through the Attic, Two-Dimensional Model . . . . . . . . . . . . . . . . . . . . . 34

12. Tests Results from Minneapolis Blower Door Test for Standard Unit (Unit

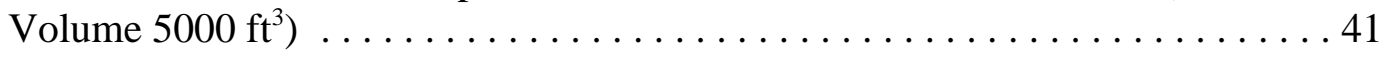

13. Tests Results from Minneapolis Blower Door Test for Upgraded Unit (Unit

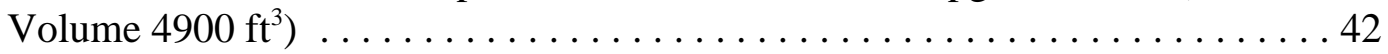

14. Comparison of Monthly Heat Pump Energy Use and Air Infiltration Energy Loss/Gain for Standard and Upgraded Manufactured Homes - 1995-1996 Data 44

15. Electric Power Use $(\mathrm{kWh})$ in the Manufactured Home Units $\ldots \ldots \ldots \ldots$ 
16. Monthly Power Use for Two Unoccupied Full-Size Single-Wide Manufactured

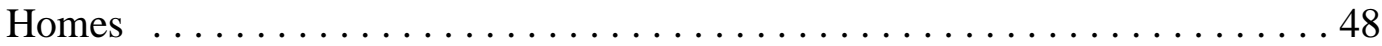

17. Multivariate Regression Results for Eq. 24 for Data Taken During Daytime Hours of June, July, and August of 1996 and 1997 . . . . . . . . . . . . . . . . . . 51

18. Comparison of Weather Variables for Selected Days from the Summers of 1996

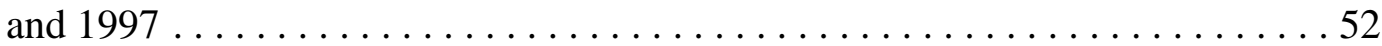

19. DOE 2.1E Roof Coating Simulations for Computational Model Tests Run with Weather Data from Nashville, Tennessee . . . . . . . . . . . . . . . . . 55

20. Annual Electrical Energy Savings for Nine Cities Based on a Roof Cavity

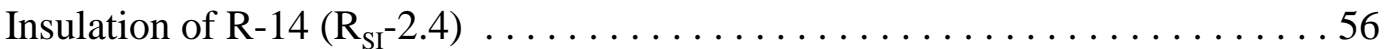

21. Apparent Thermal Conductivity Data for Roof Test Facility Rock Wool as a Function of Temperature and Density (Specimen Dimensions 24 x 24 in. at Several Thicknesses) ................................ 58

22. Vacuum Insulation Panels' Laboratory Measurements of Thermal Conductivity and Resistance at a Mean Temperature of $75^{\circ} \mathrm{f}$ (Note That the R-values Reflect the Actual Measured Panel Thicknesses) . . . . . . . . . . . . . . . . . . 59

23. Effective R-Values for a Combination of Vacuum Insulation Panels and Loose-

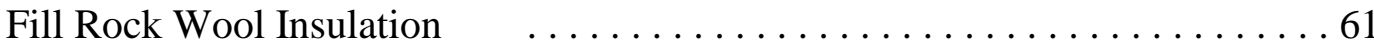




\title{
ENERGY EFFICIENCY STUDY OF SINGLE-WIDE MANUFACTURED HOMES
}

\author{
D. W. Yarbrough, G. J. Andrews, and T. K. Stovall
}

\begin{abstract}
This Cooperative Research and Development Agreement (CRADA) was among Tennessee Technological University, Clayton Homes, Inc., and Oak Ridge National Laboratory(ORNL). Manufactured homes now make up a substantial portion of the new home market, and improving the energy efficiency of these homes would save significant amounts of energy. This project explored the impact of differing levels of attic insulation, the use of evacuated insulation panels, and the application of a solar reflective roof coating. The performance of the installed roof cavity insulation compared favorably with that predicted by laboratory measurements. The more heavily insulated of the two units used about 30\% less energy over the period of the project than the standard unit. Based on the experimental data, computer simulations for nine cities were completed for a single-wide manufactured home with the solar reflective roof coating. Annual electric power savings ranged from $894 \mathrm{kWh}$ in Rapid City to $2119 \mathrm{kWh}$ for the same roof area in Los Angeles. The field performance of vacuum insulation panels was compared with laboratory performance. The panels will perform as expected if protected from puncture.
\end{abstract}

\section{OBJECTIVE OF THE CRADA}

The objectives of this CRADA were to determine relative thermal performance of the roof cavities containing two levels of insulation, determine the relative overall performance of the two single-wide manufactured homes, determine the effect of coating the exterior roof surfaces with a solar reflecting paint, determine the feasibility and performance of vacuum insulation panels in a roof cavity, and predict performance of solar reflecting roof coating in different geographical locations by modeling.

\section{BENEFITS OF CRADA TO DOE}

ORNL has been performing extensive R\&D on the development of evacuated panel superinsulation technology and on evaluating the long-term performance of reflective roof coatings for the DOE. The information developed in this CRADA had a synergistic effect on the superinsulation development program conducted by ORNL for

DOE. The cooperative agreement provided valuable field data in both of these areas for comparison with existing laboratory results. 


\section{TECHNICAL DISCUSSION OF RESULTS}

\subsection{Introduction}

This report covers work done on two full-size manufactured homes and a roofcavity test facility during the period October 1, 1993 to March 1, 1999. The work was carried out at Tennessee Technological University in Cookeville, Tennessee using two full-size single-wide manufactured homes built by Clayton Homes in Maynardville, Tennessee. The single-wide units were instrumented with calibrated heat-flux transducers and thermocouples to monitor roof cavity temperatures and ceiling heat fluxes. This instrumentation was installed as the homes were built.

The third test unit consisted of a manufactured-home roof cavity positioned above four feet of conditioned space. This unit was constructed for the purpose of testing vacuum insulation panels as roof cavity insulation. Vacuum insulation panels have high thermal resistivities that can provide needed thermal resistance in limited space. The roof cavities of many types of manufactured homes have limited space, especially near the edges.

The full-size units used in the study had roof-cavity insulation at two levels. The first unit had a standard insulation package consisting of sufficient thickness of fiberglass batts to provide a nominal $\mathrm{R}-14\left(\mathrm{ft}^{2} \bullet \mathrm{h} \bullet{ }^{\circ} \mathrm{F} / \mathrm{Btu}\right)\left[\mathrm{R}_{\mathrm{SI}^{-}}-2.4\left(\mathrm{~m}^{2} \bullet \mathrm{K} / \mathrm{W}\right)\right]$. The second unit contained an upgraded insulation package consisting of nominal R-28 ( $\left.\mathrm{R}_{\mathrm{SI}^{-}}-4.8\right)$ fiberglass batt insulation. The roof cavity test facility contained loose-fill rock wool insulation installed by an insulation contractor to a nominal R-19 $\left(\mathrm{R}_{\mathrm{SI}^{-}}-3.3\right)$ level.

The broad objectives of this project are listed below:

- Determine relative thermal performance of the roof cavities containing two levels of insulation.

- $\quad$ Determine the relative overall performance of the two single-wide manufactured homes.

- Determine the effect of coating the exterior roof surfaces with a solar reflecting paint. 
- $\quad$ Determine the feasibility and performance of vacuum insulation panels in a roof cavity.

- $\quad$ Predict performance of solar reflecting roof coating in different geographical locations by modeling.

The broad objectives were supported by a number of technical projects, the descriptions of which are contained in this report.

Construction guidelines for manufactured homes are set by the United States Department of Housing and Urban Development. These guidelines establish thermal and ventilation standards. As indicated above, a major objective of this project was to determine if the energy efficiency of a particular manufactured housing design could be improved with modifications to the standard roof-cavity insulation package. As more manufactured homes are built, it is important to explore the possibilities of energy conservation, especially in the lower cost homes.

This report describes experimental work with manufactured homes commonly manufactured and marketed in the United States. As such, these homes and their components are typically described in English units of inches, feet, British Thermal Units (BTU's), etc. The metric equivalent of these units is included throughout this text within parentheses. One English unit that appears repeatedly is the " $R$-value" of insulation. The $R$-value is expressed in units of $f t^{2} \bullet h \bullet{ }^{\circ} \mathrm{F} /$ Btu. The metric equivalent within this report is designated the " $R_{S I}$-value" and has units of $m^{2} \bullet K / W$. 


\subsection{Description of Test Units and Instrumentation}

\subsubsection{Full-Size Manufactured Homes}

The test units for this project consisted of two 14 -ft-wide by 52 -ft-long $(4.3 \mathrm{~m}$ wide by $16 \mathrm{~m}$ long) single-wide manufactured home units. Each manufactured home contained R-11 ( $\left.\mathrm{R}_{\mathrm{SI}}-1.9\right)$ fiberglass batts for insulation in the 16-in. on center, 2x4-in. $(0.41 \mathrm{~m}$ on center, $0.05 \times 0.1 \mathrm{~m})$ stud walls. The outside of the walls were covered with a thin cardboard sheet that is an air infiltration barrier. White aluminum siding was installed on the outside of this air infiltration barrier and attached to the wall framing with screws. The inside walls and ceiling were covered with nominal 3/8-in.-thick $(0.01 \mathrm{~m})$ gypsum board. The interior walls of the unit contained no thermal or acoustical insulation. Each unit had seven windows that were frame-type construction containing dual-pane glass. The windows remained closed throughout the study. Each unit had two exterior hollow wooden doors that were coated with a thin white plastic coating.

The flooring was made from 5/8-in.-thick $(0.016 \mathrm{~m})$ compressed particle board that rested on 16-in. on center, $2 \times 6$-in. ( $0.41 \mathrm{~m}$ on center, $0.05 \mathrm{x} 0.15 \mathrm{~m}$ ) joists. The joists were supported by a chassis that was placed on concrete masonry blocks and anchored to the ground. Underpin skirting made of polyvinyl chloride sheets was used as a crawlspace wind barrier.

The roof joists and trusses were made of nominal $2 \times 2$-in. $(0.05 \times 0.05 \mathrm{~m})$ wood lumber set 24-in. $(0.61 \mathrm{~m})$ on center. The joists are attached to the top of the ceiling gypsum board. The roof trusses are covered with a 0.012-in.-thick $(0.0003 \mathrm{~m})$ polished unpainted aluminum sheet. The roof cavity is unventilated.

The manufacturer's standard unit (at the time this project was initiated) contained two layers of $\mathrm{R}-7$ ( $\left.\mathrm{R}_{\mathrm{SI}}-1.2\right)$ fiberglass batts and the upgraded unit contained four layers of $\mathrm{R}-7\left(\mathrm{R}_{\mathrm{SI}^{-}}-1.2\right)$ fiberglass batts. One of the $\mathrm{R}-7\left(\mathrm{R}_{\mathrm{SI}^{-}}-1.2\right)$ batts in the upgraded unit was installed below the roof to form a "rumble" blanket. The other batts were all placed on the ceiling gypsum board, parallel to the ceiling joists and between these joists. The only design difference between the two manufactured homes was the additional two layers of 
$\mathrm{R}-7$ ( $\left.\mathrm{R}_{\mathrm{SI}}-1.2\right)$ fiberglass batts installed in the roof cavity of the upgraded unit.

Figure 1 contains a photograph of the single-wide units which shows the manufactured home skirting that was used for crawlspace wind barriers. The photograph shows the absence of shading by trees or buildings. These units were placed nine $\mathrm{ft}$ ( 2.7 $\mathrm{m})$ apart on a gravel surface. The test site was located on the Tennessee Technological University campus in an undisturbed area that is unhindered by buildings or trees. The two units were positioned in an east to west orientation to avoid shading of one unit by the other.

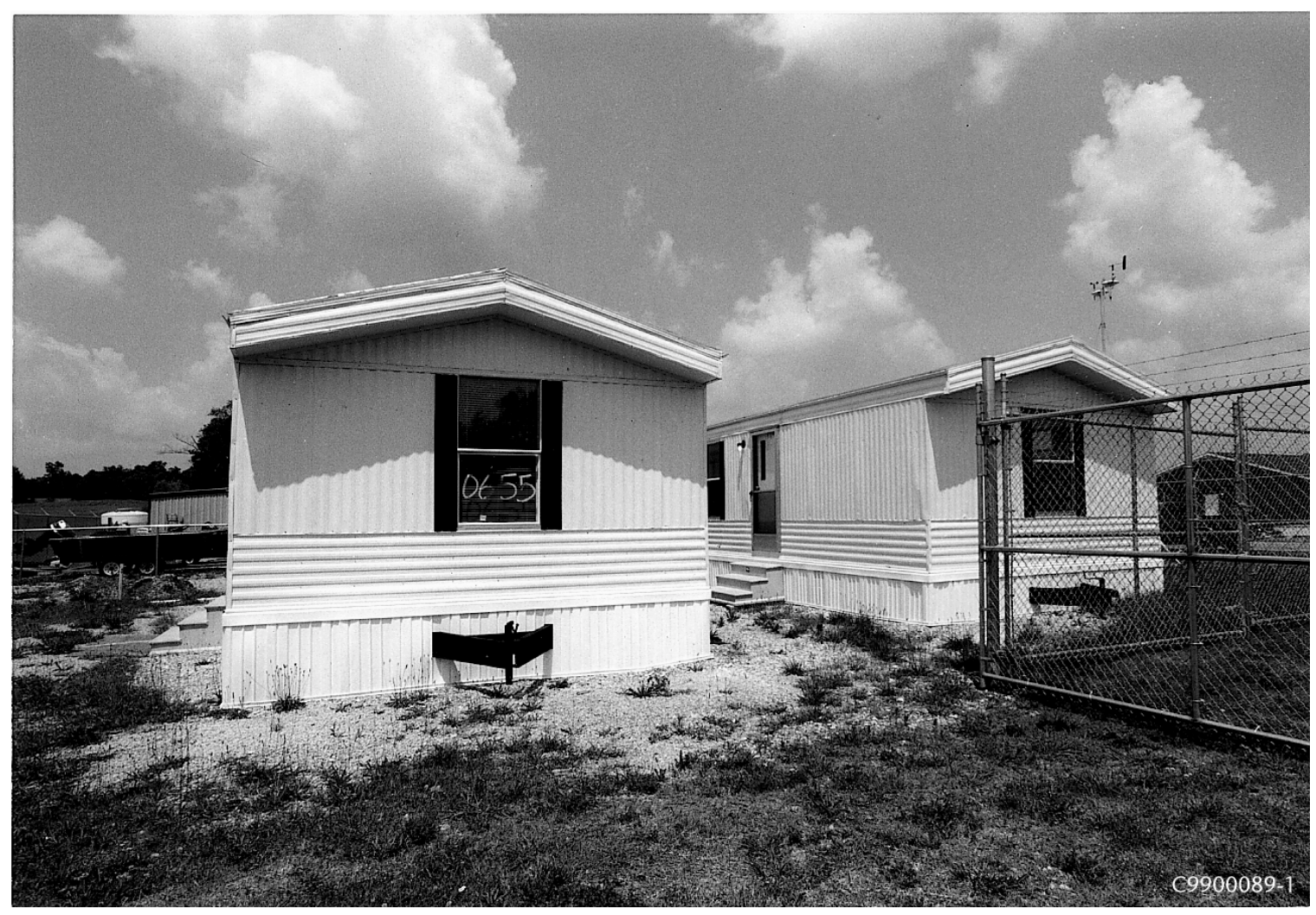

Figure 1. End/side view of manufactured homes used in this project.

Two box-type fans were placed in each unit to provide air circulation and reduce interior air temperature variations. One computer operated continuously in the upgraded unit for heat flux transducer and thermocouple data collection for all units. Water heaters were powered in both units but there was no use of hot water. Minimal occupation of the units took place during the study. Interior lights were used a few hours each month while 
small exterior lights were on continuously for security reasons.

Thermocouples and heat flux transducers were placed in the insulated roof cavity at the time of manufacture to measure roof cavity temperatures and ceiling heat flows. Each heat flux transducer was placed on top of the ceiling, taped to prevent movement, and covered by the roof cavity insulation. Three of these heat flux transducers were

\begin{tabular}{|ll|}
\hline & C \\
A & B \\
& \\
& \\
\hline
\end{tabular}

Figure 2. Heat flux transducer and thermocouple locations in the full-size manufactured homes.

placed along the centerline of the roof cavity in each unit. One heat flux transducer was placed on the edge of the roof cavity approximately one ft from the exterior wall in each unit. For this report, there are four labeled measurement positions within the attic space, A, B, C, and D, as shown in Figure 2. Although these positions vary by a few inches between the two homes, they are essentially the same. Heat flux transducer and thermocouple measurements are available for these locations. Multiple temperature measurements are made through the height of the attic assembly at the A and D locations, as shown in Table 1.

Each manufactured home unit was equipped with the same model heat pump system. The power to the heat pump and its fan were metered together, while the power to the backup resistive heater was metered separately. The meters were placed between the main circuit breaker and the heat pump. Electrical energy consumption for lights and computer equipment were not included in the submetered energy used for heating and cooling. The electrical energy consumption for the heat pump and resistive heaters were recorded several times per month.

The heat pump was controlled by a Honeywell Tradeline thermostat with an automatic changeover for heating and cooling requirements. The automatic changeover 
feature allows heating or cooling to take place upon demand and was needed in transient weather months when both heating and cooling were needed since the units were not occupied on a full-time basis.

Table 1. Thermocouple Locations in the Full-size Manufactured Home Attics

\begin{tabular}{|l|l|l|}
\hline $\begin{array}{l}\text { Horizontal location (as } \\
\text { shown on Fig. 2) }\end{array}$ & Label & Vertical location \\
\hline A & TCA1 & top ridge \\
\hline A & TCA2 & gypsum board (attic-side) \\
\hline A & TCA3 & near hft A \\
\hline D & TCD1 & near hft D \\
\hline D & TCD2 & gypsum board (attic-side) \\
\hline D & TCD3 & top of fiberglass \\
\hline D & TCD4 & top ridge \\
\hline D & TCD5 & attic air \\
\hline
\end{tabular}

a placed between the wood rafter and aluminum roof assembly covering to measure the roof temperature

The thermostats were mounted about five $\mathrm{ft}$ above the floor in the hallway. This placement minimized the effect of drafts and solar heating from windows. A check was made periodically with a digital thermometer to assure that the thermostat set points were remaining constant. This was accomplished by observing the temperatures at which the system would turn on and off during heating or cooling. While in normal operation, the interior temperature fluctuates $\pm 2^{\circ} \mathrm{F}\left( \pm 1^{\circ} \mathrm{C}\right)$ from the thermostat set point. When the outer limit is reached, the heat pump will supply heating or cooling to return the temperature to the set point.

\subsubsection{Roof Cavity Test Unit}

The roof-cavity test facility was constructed by mounting standard 14-ft-wide (4.3 m) manufactured home roof trusses on a base made with $2 \times 6-i n .(0.05 \times 0.15 \mathrm{~m})$ stud 
wall construction. The roof-cavity test facility is 24 -ft-long with 4 -ft-high $(7.3 \mathrm{~m}$ long with $1.2 \mathrm{~m}$ high) walls. This base design was chosen to reduce the heat loss/gain to the interior conditioned space. The structure had a single access door and no windows. A through-the-wall heating/cooling unit was provided to maintain a constant temperature inside the test facility. Electric fans were positioned to move air inside the conditioned space and reduce interior temperature variations. Figures 3 and 4 show the details of the roof test facility.

The roof sheathing for the test facility was built in sections that were hinged near

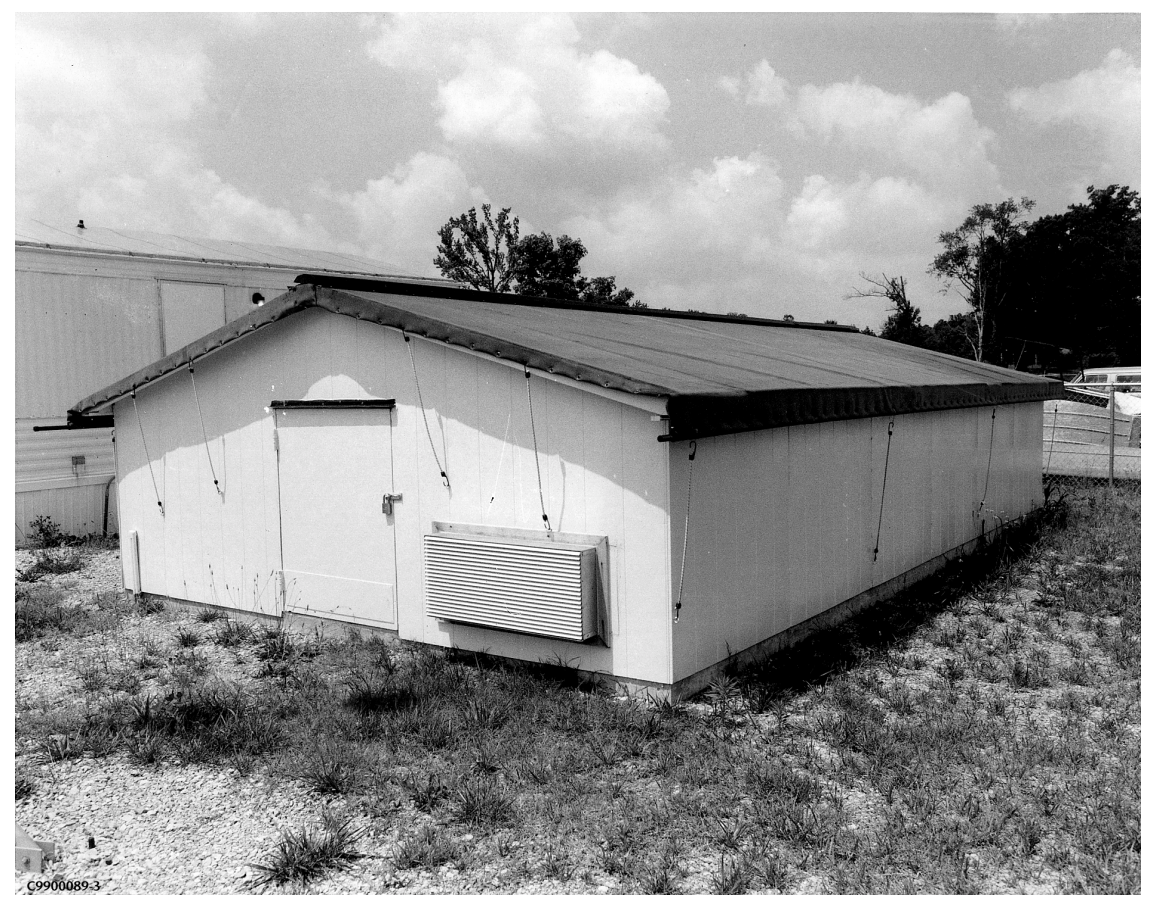

Figure 3. Photograph of roof test facility.

the peak of the roof. The system permitted access to specific regions of the roof cavity for installation of insulation, thermocouples and heat-flux transducers. The middle section of the north half of the test facility was the primary site for the present study. This section contained three bays formed by four trusses set 24 -in. $(0.6 \mathrm{~m})$ on center. Each of the three bays was instrumented with two calibrated heat flux transducers and thermocouples to measure temperatures in the roof cavity. The transducer positions are shown in Figure 5, which is not drawn to scale. 


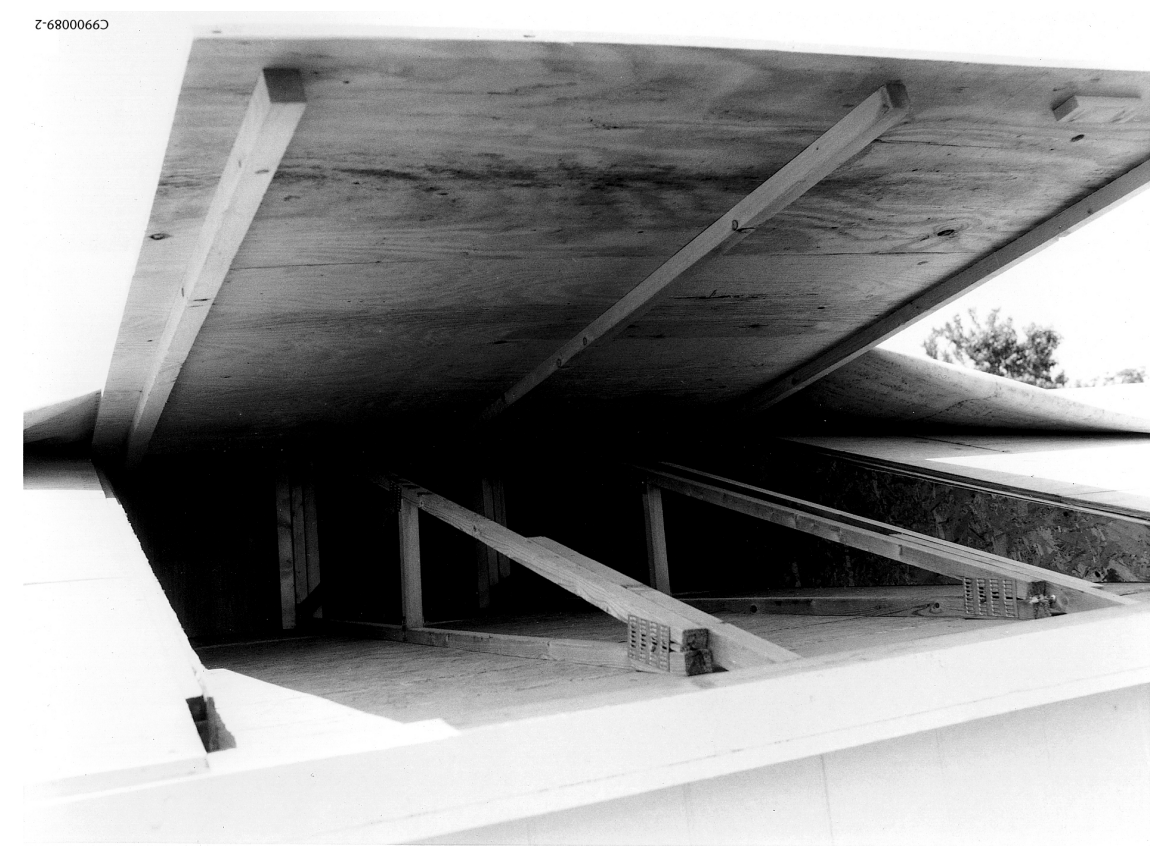

Figure 4. Photograph of roof test facility with one test section open.

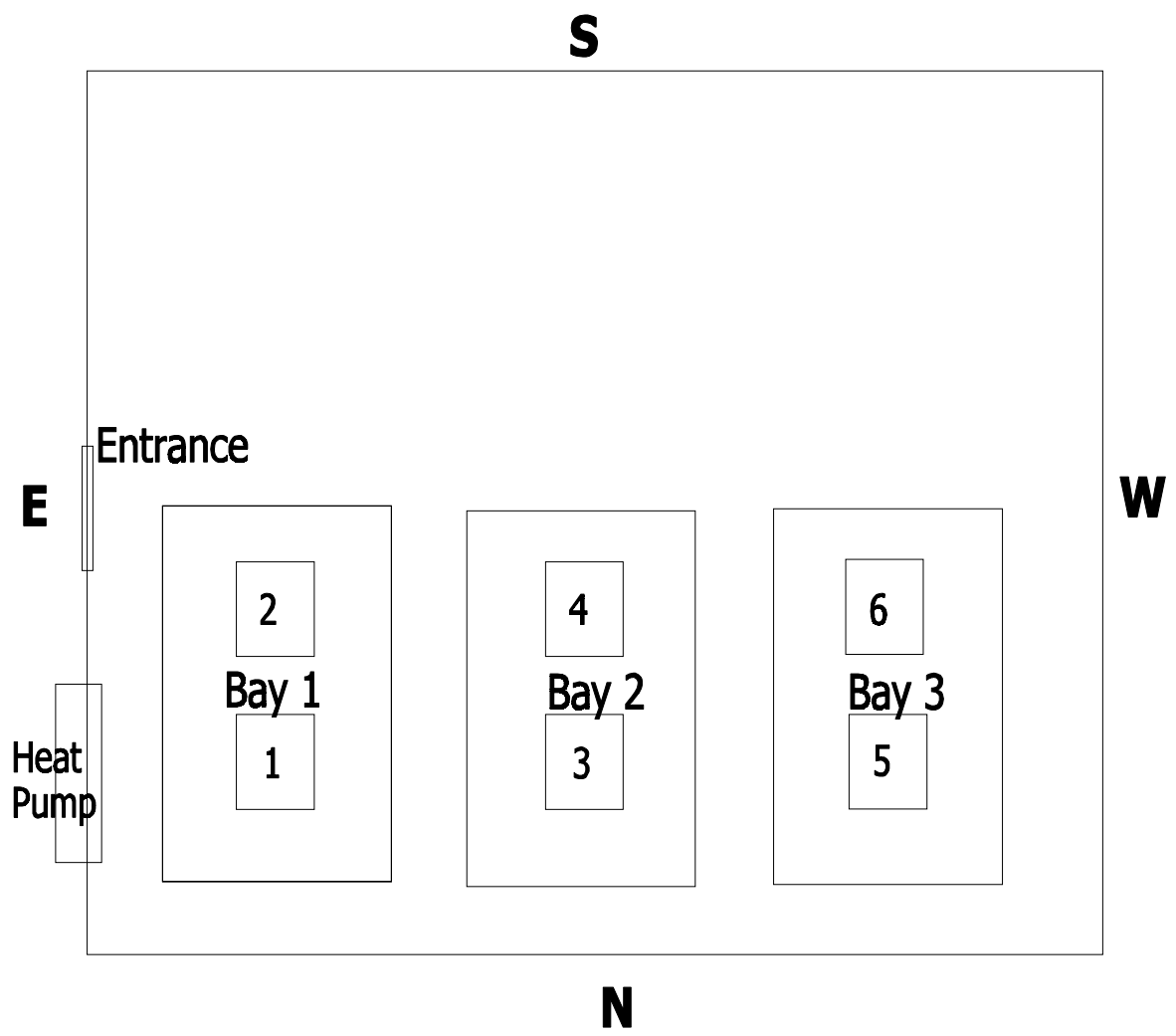

Figure 5. Vacuum panel and heat flux transducer positions in the roof test facility (not to scale). 
Loose-fill rock wool insulation was installed in all three bays by an insulation contractor. The rock wool insulation was installed on top of the vacuum insulation panels, thus filling the 22-in.-wide $(0.56 \mathrm{~m})$ space between trusses on the north half of the test facility. The panels were located as shown in Fig. 5 and Table 2. The panels were approximately 3/4-in. $(0.02 \mathrm{~m})$ thick. The rock wool insulation was manufactured by American Rock Wool Company located in Spring Hope, North Carolina. The target Rvalue for the installed rock wool was R-19 $\left(\mathrm{R}_{\mathrm{SI}^{-}}-3.3\right)$. All of the bays in the roof test facility were insulated with loose-fill rock wool at the R-19 $\left(\mathrm{R}_{\mathrm{SI}^{-}}-3.3\right)$ level to reduce the load on the heating/cooling equipment.

Table 2. Heat Flux Transducer and Vacuum Panel Locations in the Roof Test Facility

\begin{tabular}{|l|l|l|l|}
\hline Location ID & Location & Transducer & Vacuum panel ID \\
\hline 1 & Bay 1, North & ORNL - \#R1 & 18240212 \\
\hline 2 & Bay 1, South & ORNL - \#R2 & 18240217 \\
\hline 3 & Bay 2, North & ORNL - \#R3 & 18240223 \\
\hline 4 & Bay 2, South & ORNL - \#R4 & 18240210 \\
\hline 5 & Bay 3, North & ORNL - \#R5 & 18240221 \\
\hline 6 & Bay3, South & ORNL - \#R7 & 18240218 \\
\hline
\end{tabular}

\subsubsection{Heat Flux Transducers and Thermocouples}

The collection and archival of heat flux transducer and thermocouple data were accomplished by using a data acquisition system that was designed and built by LaserComp, Inc. of Lynnfield, Massachusetts. The 8 x 8 in. (0.2 x $0.2 \mathrm{~m})$ heat flux transducers were constructed using a ceramic plate that contains embedded thermocouples to form a thermopile. These transducers react to a heat flow across the insulation batt and create an output voltage that is proportional to the heat flux. The heat flux transducers were calibrated (in the same configuration they were to be used) by placing them as test specimens in a heat flow meter built and operated in accordance with 
ASTM C 518. ${ }^{1}$ The output voltages were measured as a function of heat flux for three to five heat fluxes at a constant average temperature. The ratio of the heat flux to the output voltage is the calibration factor. Table 3 shows these calibration factors for the transducers used in this project.

Type-T thermocouples were used for temperature measurements. Heat flux and temperature data were read by the data acquisition system every 12 minutes. Every 60 minutes, these 12 minute readings were averaged and stored as one-hour averages.

Table 3. Calibration Factors for Heat Flux Transducers Installed in the Roof Cavities of the Manufactured Home Units and the Roof Test Facility

\begin{tabular}{|l|l||l|l|}
\hline \multicolumn{2}{|c|}{ Manufactured Home Units } & \multicolumn{2}{c|}{ Roof Test Facility } \\
\hline $\begin{array}{l}\text { Heat Flux } \\
\text { Transducer Number }\end{array}$ & $\begin{array}{l}\text { Calibration Factor } \\
\left(\text { Btu/hr॰ft }{ }^{2}\right) / \\
(\text { millivolt })\end{array}$ & $\begin{array}{l}\text { Heat Flux } \\
\text { Transducer Number }\end{array}$ & $\begin{array}{l}\text { Calibration Factor } \\
\left(\text { Btu/hr॰ft }{ }^{2}\right) / \\
(\mathrm{millivolt})\end{array}$ \\
\hline ORNL - \#1 & 3.8196 & ORNL - \#R1 & 7.0918 \\
\hline ORNL - \#2 & 2.7866 & ORNL - \#R2 & 3.5128 \\
\hline ORNL - \#3 & 3.7066 & ORNL - \#R3 & 3.0326 \\
\hline ORNL - \#4 & 3.8940 & ORNL - \#R4 & 3.6499 \\
\hline ORNL - \#5 & 3.2980 & ORNL - \#R5 & 2.7853 \\
\hline ORNL - \#6 & 3.8420 & ORNL - \#R6 & 2.7403 \\
\hline ORNL - \#7 & 3.5385 & ORNL - \#R7 & 3.7086 \\
\hline ORNL - \#8 & 3.4335 & & \\
\hline
\end{tabular}

\subsubsection{On-Site Weather Data Collection}

On-site weather conditions were measured and collected from a weather station located approximately $30 \mathrm{ft}$ from the manufactured home units. This weather station was capable of measuring and collecting dry bulb air temperature, wind speed and direction, relative humidity, and solar radiation on an hourly basis. Figure 1 shows the weather station instrumentation rising behind the manufactured homes. 
The weather station failed early in 1998 due to electrical storms. The station was repaired and reinstalled but did not function satisfactorily. Analysis using local weather data, therefore, are limited to the early part of the project. 


\subsection{HEAT FLOW IN THE FULL-SIZE MANUFACTURED HOMES}

\section{$\underline{\text { 3.3.1 Laboratory Measurements }}$}

The thermal resistance of batt insulation used in this project was measured using a heat-flow-meter apparatus built and operated in accordance with ASTM C 518 ${ }^{1}$. These laboratory measurements were conducted to determine the apparent thermal conductivity of the fiberglass batts used in the manufactured home roof cavities. Sixteen measurements were made using the heat flow meter apparatus on single-thickness batt specimens. Tests were conducted at three average specimen temperatures at each of four insulation densities. Four tests were made at each density. The test temperatures were at 50,75 , and $100^{\circ} \mathrm{F}\left(10,24\right.$, and $\left.38{ }^{\circ} \mathrm{C}\right)$, and a repeated test at $75^{\circ} \mathrm{F}\left(24^{\circ} \mathrm{C}\right)$. An equation for apparent thermal conductivity, as a function of temperature and density, was developed from the heat-flow meter measurements.

The model used assumes that the thermal conductivity varies with density as shown in Eq. (1) where $\mathrm{k}_{\mathrm{a}}$ is the apparent thermal conductivity, a,b,c are the model fit parameters, and $\rho$ is the density.

$$
k_{a}=a+b \rho+\frac{c}{\rho}
$$

The temperature dependence of $\mathrm{k}_{\mathrm{a}}$ was taken to be linear and Eq. (2) follows from Eq. (1) where $\alpha, \beta$ are model fit parameters and $\mathrm{T}$ is the mean specimen temperature.

$$
k_{a}(\rho, \bar{T})=\left(\alpha_{1}+\left(\beta_{1} * \bar{T}\right)\right)+\left(\alpha_{2}+\left(\beta_{2} * \bar{T}\right)\right) \rho+\frac{\left(\alpha_{3}+\left(\beta_{3} * \bar{T}\right)\right)}{\rho}
$$

The method of least squares was used to develop Eq. (3) where $\overline{\mathrm{T}}$ is in ${ }^{\circ} \mathrm{F}$ and $\rho$ has units of $\mathrm{lb} / \mathrm{ft}^{3}$. 


$$
\begin{gathered}
k_{a}=(-0.070687+6.98879 E-04 * \bar{T})+(0.060689-4.9234 E-4 * \bar{T}) \rho \\
+\frac{(0.031972-1.9602 E-4 * \bar{T})}{\rho}
\end{gathered}
$$

The resulting fit is a thermal conductivity equation that is a function of both temperature and density. Table 4 shows results from laboratory heat flow measurements. Table 5 shows the deviation between the calculated, using Eq. (3), and measured values [the deviation is defined as $\left(\mathrm{k}_{\text {experiment }}-\mathrm{k}_{\text {calculated }}\right) / \mathrm{k}_{\text {calculated }}$. Eq. 3 describes the experimental $\mathrm{k}_{\mathrm{a}}$ data to better than $\pm 1.5 \%$. 
Table 4. Apparent Thermal Conductivity Data for Fiberglass Batt Insulation as a Function of Temperature and Density

\begin{tabular}{|c|c|c|c|}
\hline $\begin{array}{l}\text { Specimen Mass } \\
\text { Specimen Dimensions }\end{array}$ & \multicolumn{3}{|c|}{$\begin{array}{l}0.1971 \mathrm{lbs}(0.0894 \mathrm{~kg}) \\
12 \times 12 \mathrm{in} .(0.3 \times 0.3 \mathrm{~m}) \text { at several thicknesses }\end{array}$} \\
\hline Thickness (ft) & $\begin{array}{c}\overline{\mathrm{T}} \\
\left({ }^{\circ} \mathrm{F}\right)\end{array}$ & $\begin{array}{c}\mathrm{k}_{\mathrm{a}} \\
\left(\mathrm{Btu} / \mathrm{hr} \bullet \mathrm{ft} \bullet{ }^{\circ} \mathrm{F}\right)\end{array}$ & $\underset{\left(\mathrm{lb} / \mathrm{ft}^{3}\right)}{\rho}$ \\
\hline \multirow[t]{3}{*}{0.2917} & 50.02 & 0.0216 & 0.6757 \\
\hline & 75.04 & 0.0232 & \\
\hline & 100.06 & 0.0254 & \\
\hline \multirow[t]{4}{*}{0.2789} & 50.02 & 0.0212 & 0.7067 \\
\hline & 75.04 & 0.0228 & \\
\hline & 100.06 & 0.0249 & \\
\hline & 75.04 & 0.0229 & \\
\hline \multirow[t]{4}{*}{0.2690} & 50.02 & 0.0211 & 0.7327 \\
\hline & 75.04 & 0.0226 & \\
\hline & 100.06 & 0.0246 & \\
\hline & 75.04 & 0.0226 & \\
\hline \multirow[t]{4}{*}{0.2624} & 50.02 & 0.0210 & 0.7513 \\
\hline & 75.04 & 0.0224 & \\
\hline & 100.06 & 0.0244 & \\
\hline & 75.04 & 0.0224 & \\
\hline
\end{tabular}


Table 5. Comparison of Apparent Thermal Conductivity Measured to That Predicted by Eq. 3 for Fiberglass Batt Insulation as a Function of Temperature and Density

\begin{tabular}{|c|c|c|c|c|}
\hline $\begin{array}{c}\text { Average Insulation } \\
\text { Temp. } \\
\left({ }^{\circ} \mathrm{F}\right)\end{array}$ & $\begin{array}{c}\text { Density } \\
\left(\mathrm{lb} / \mathrm{ft}^{3}\right)\end{array}$ & $\begin{array}{c}\mathrm{k}_{\text {calculated }} \\
(\mathrm{Btu} / \mathrm{ft} \bullet \bullet\end{array}$ & $\begin{array}{c}\left.{ }^{\circ} \mathrm{F}\right) \\
\left(\mathrm{Btu} / \mathrm{ft} \bullet{ }^{\circ} \bullet{ }^{\circ} \mathrm{F}\right)\end{array}$ & $\begin{array}{c}\text { Deviation } \\
(\%)\end{array}$ \\
\hline 50.02 & 0.6757 & 0.0214 & 0.0216 & 0.93 \\
\hline 75.04 & 0.6757 & 0.0233 & 0.0232 & -0.43 \\
\hline 100.06 & 0.6757 & 0.0252 & 0.0254 & 0.79 \\
\hline 75.04 & 0.6757 & 0.0233 & 0.0232 & -0.43 \\
\hline 50.02 & 0.7067 & 0.0211 & 0.0212 & 0.47 \\
\hline 75.04 & 0.7067 & 0.0230 & 0.0228 & -0.87 \\
\hline 100.06 & 0.7067 & 0.0248 & 0.0249 & 0.40 \\
\hline 75.04 & 0.7067 & 0.0230 & 0.0229 & -0.43 \\
\hline 50.02 & 0.7327 & 0.0209 & 0.0211 & 0.96 \\
\hline 75.04 & 0.7327 & 0.0227 & 0.0225 & -0.88 \\
\hline 100.06 & 0.7327 & 0.0249 & 0.0246 & -1.20 \\
\hline 75.04 & 0.7327 & 0.0227 & 0.0226 & -0.44 \\
\hline 50.02 & 0.7513 & 0.0209 & 0.0210 & 0.48 \\
\hline 75.04 & 0.7513 & 0.0225 & 0.0224 & -0.44 \\
\hline 100.06 & 0.7513 & 0.0242 & 0.0244 & 0.83 \\
\hline 75.04 & 0.7513 & 0.0225 & 0.0224 & -0.44 \\
\hline & & & & \\
\hline
\end{tabular}




\subsubsection{Field Data Analysis - Ceiling Heat Flux Through the Insulation}

One-dimensional heat transfer across insulation is described by Fourier's Law. Equation (4) shows that the rate of heat flow per unit area $\left(\mathrm{q}^{\prime}\right)$ through the insulation as a function of the apparent thermal conductivity $(\mathrm{k})$ and the temperature gradient $(\mathrm{dT} / \mathrm{dx})$.

$$
q^{\prime}=\frac{Q}{A}=-k\left(\frac{d T}{d x}\right)
$$

Where $\mathrm{Q}$ is the total heat flow and A is the insulation area. Equation (4) may be integrated with constant heat flow rate to obtain Eq. (5) which equates a resistance (R) to the ratio of the thermal driving force $(\Delta \mathrm{T}$, the temperature difference) to the heat flux $\left(q^{\prime}\right)$.

$$
R=\frac{\Delta T}{q^{\prime}}
$$

Heat fluxes were measured in this project by calibrated heat flux transducers placed between the ceiling and the insulation in the roof cavity. Type-T thermocouples were used to measure temperature differences across the insulation batts in the roof cavity. Time averages of the heat flow and temperature data were used to calculate Rvalues for the roof-cavity insulation. Equation (6) shows the time averaging technique that was used for thermal resistance.

$$
\bar{R}=\frac{\int_{t_{1}}^{t_{2}}\left|\frac{\Delta T}{q^{\prime}}\right| d t}{t_{2}-t_{1}}
$$

Where $\bar{R}$ is the average thermal resistance and $t$ is the time. Upon integration over a onehour time interval, Eq. (6) reduces to Eq. (7) for $\overline{\mathrm{R}}_{\text {hour }}$. 


$$
\begin{aligned}
\bar{R}_{\text {hour }} & =\overline{\left|\left(\frac{\Delta T}{q^{\prime}}\right)\right|} \\
\bar{R}_{\text {month }} & =\frac{\sum_{j=1}^{n} R_{\text {hour }_{j}}}{n}
\end{aligned}
$$

Equation (4) was used to calculate hourly average R-values, and Eq. (8) was used to calculate the monthly average R-values from the hourly R-value data.Equation (5) shows that heat flux ( $\mathrm{q}^{\prime}$ ) values close to zero result in very large values for $\overline{\mathrm{R}}_{\text {hour }}$. These low heat fluxes occur when indoor and outdoor temperatures differ by a few degrees or when the heat flow direction changes. Additional thermal resistance average calculations were made to determine the effect of excessively large thermal resistances on the monthly $\mathrm{R}$-value average $\left(\overline{\mathrm{R}}_{\text {month }}\right)$. In the first calculation, average hourly $\mathrm{R}$-values that exceeded $30 \mathrm{hr} \bullet \mathrm{ft}^{2} \bullet{ }^{\circ} \mathrm{F} / \mathrm{Btu}\left(5.2 \mathrm{~m}^{2} \bullet \mathrm{K} / \mathrm{W}\right)$ were discarded from the set used to calculate $\overline{\mathrm{R}}_{\text {month }}$ using Eq. (8). A second calculation was made using the same procedure except that the Rvalues greater than $40 \mathrm{hr} \bullet \mathrm{ft}^{2} \bullet{ }^{\circ} \mathrm{F} / \mathrm{Btu}\left(6.7 \mathrm{~m}^{2} \bullet \mathrm{K} / \mathrm{W}\right)$ were discarded. A third calculation excluded $\overline{\mathrm{R}}_{\text {hour }}$ values greater than $50 \mathrm{hr} \bullet \mathrm{ft}^{2} \bullet{ }^{\circ} \mathrm{F} / \mathrm{Btu}\left(8.7 \mathrm{~m}^{2} \bullet \mathrm{K} / \mathrm{W}\right)$. Comparison of these three calculations determined that in most cases the anomalous R-values made less than 1 $\%$ difference in the calculated values for $\bar{R}_{\text {month }}$. Since the $\overline{\mathrm{R}}_{\text {month }}$ values between 30,40 , and $50 \mathrm{hr} \bullet \mathrm{ft}^{2} \bullet{ }^{\circ} \mathrm{F} / \mathrm{Btu}\left(5.2,6.7\right.$, and $\left.8.7 \mathrm{~m}^{2} \bullet \mathrm{K} / \mathrm{W}\right)$ differed only by $1 \%, \overline{\mathrm{R}}_{\text {month }}$ values calculated by the three methods were averaged.

The field data showed that there was a significant increase in the thermal resistance for the winter months. To compare this data to the laboratory data, four thickness measurements were made for the section of fiberglass batt that rests above each heat flux transducer. The average thickness of these four measurements was used to calculate a density. These four thickness measurements are contained in Table 6. Because the fiberglass batts are uniform (in terms of mass per unit area), these thickness values were transformed to density values using the data shown in Table 4. A thermal resistance for the insulation batt can then be determined as a function of temperature and density using Eq. (3). Figures 6 and 7 and Table 7 report results for the standard and 
Table 6. Fiberglass Batt Field Thickness Measurements [in. (m)]

\begin{tabular}{|c|c|c|c|c|c|c|}
\hline Measurement & \multicolumn{2}{|c|}{ Position A } & \multicolumn{2}{|c|}{ Position B } & \multicolumn{2}{|c|}{ Position D } \\
\hline \multicolumn{7}{|c|}{$\underline{\text { Standard Manufactured Unit }}$} \\
\hline$\# 1$ & 4.5 & $(0.114)$ & 4.5 & $(0.114)$ & 4.6 & $(0.116)$ \\
\hline$\# 2$ & 4.4 & $(0.113)$ & 4.9 & $(0.124)$ & 4.3 & $(0.108)$ \\
\hline \#3 & 5.0 & $(0.127)$ & 5.1 & $(0.129)$ & 4.6 & $(0.117)$ \\
\hline \#4 & 4.5 & $(0.114)$ & 5.3 & $(0.135)$ & 4.6 & $(0.118)$ \\
\hline Average & 4.6 & $(0.117)$ & 5.0 & $(0.126)$ & 4.5 & $(0.115)$ \\
\hline \multicolumn{7}{|c|}{ Upgraded Manufactured Unit } \\
\hline$\# 1$ & 7.8 & $(0.197)$ & 7.4 & $(0.189)$ & 7.5 & $(0.190)$ \\
\hline$\# 2$ & 7.8 & $(0.199)$ & 7.6 & $(0.194)$ & 7.4 & $(0.189)$ \\
\hline \#3 & 7.7 & $(0.195)$ & 7.8 & $(0.197)$ & 7.4 & $(0.188)$ \\
\hline \#4 & 7.8 & $(0.199)$ & 7.5 & $(0.190)$ & 7.3 & $(0.186)$ \\
\hline Average & 7.8 & $(\mathbf{0 . 1 9 8})$ & 7.6 & $(\mathbf{0 . 1 9 3})$ & 7.4 & $(\mathbf{0 . 1 8 8})$ \\
\hline
\end{tabular}

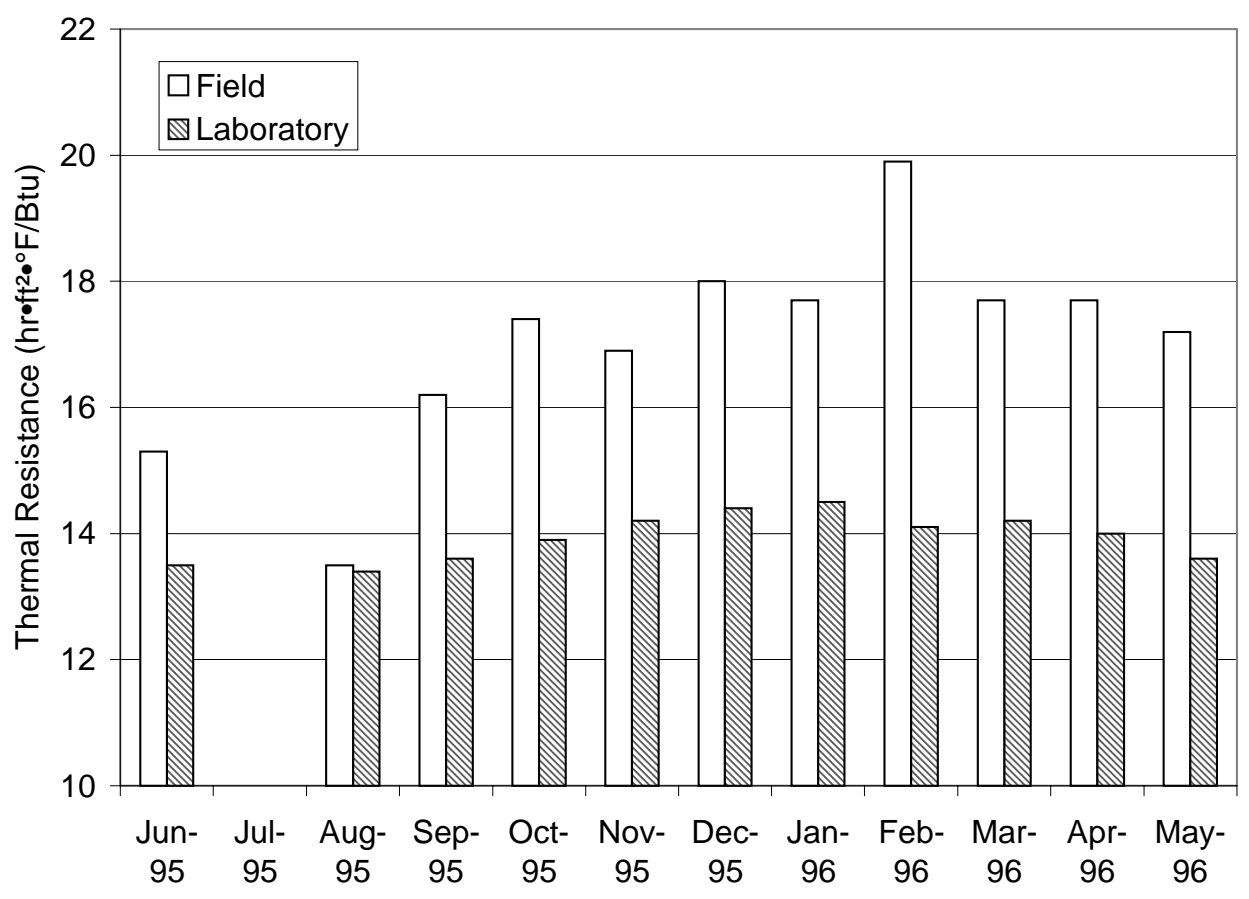

Figure 6. Comparison of field-measured roof cavity insulation thermal resistance to laboratory-measured data for the standard manufactured home unit. 


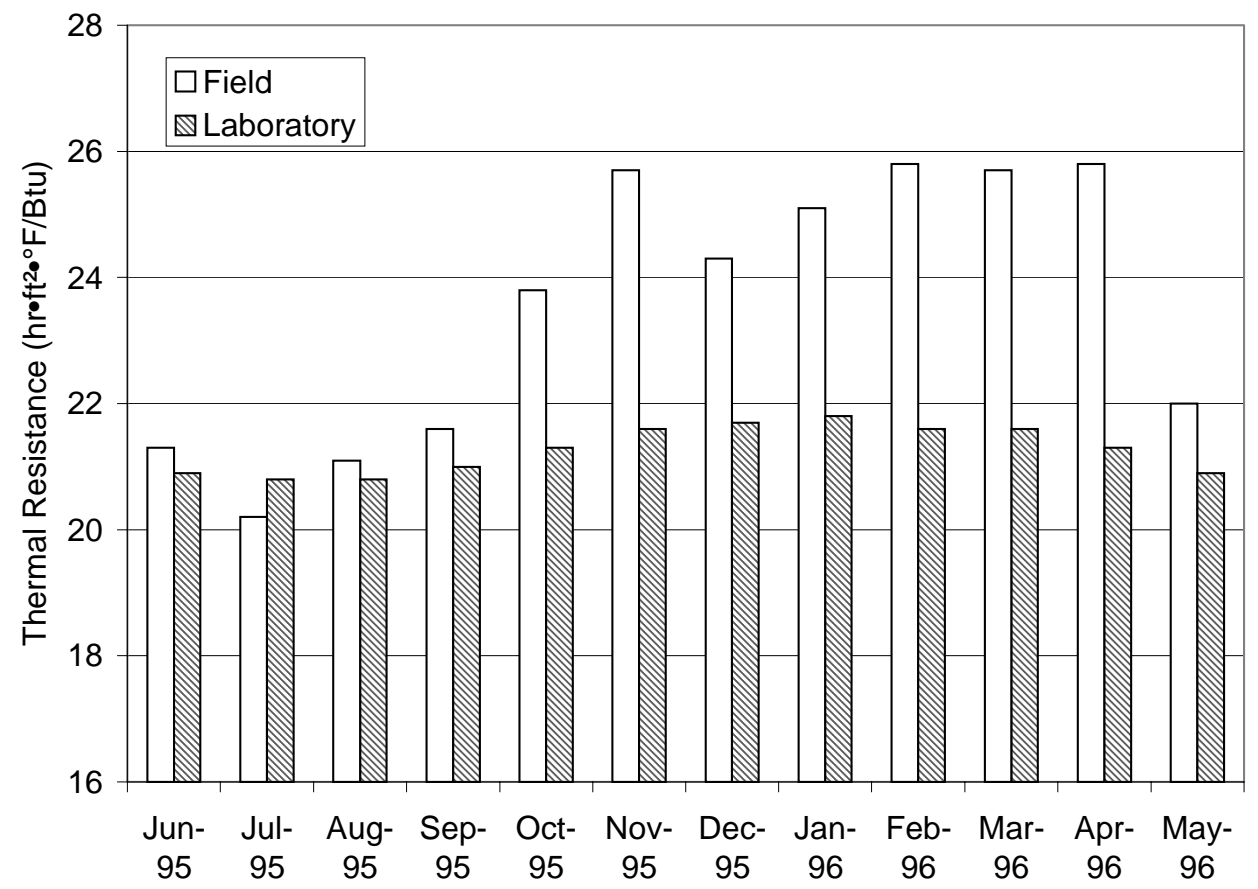

Figure 7. Comparison of field-measured roof cavity insulation thermal resistance to laboratory-measured data for the upgraded manufactured home unit (batt installed against the roof not included here).

density using Eq. (3). Figures 6 and 7 and Table 7 report results for the standard and upgraded manufactured home units' measured thermal resistance. The standard unit monthly averages for November through March show a $21 \%$ greater thermal resistance than the thermal resistance predicted by the laboratory thermal conductivity measured at the same temperature. Summer monthly averages show a $6 \%$ greater thermal resistance than the thermal resistance calculated from the laboratory measurements.

The upgraded unit's winter monthly averages showed a $14 \%$ greater thermal resistance than those predicted by the laboratory measurements. Summer monthly averages showed a $1 \%$ greater thermal resistance than those predicted by the laboratory measurements. (These measurements and comparisons for the upgraded unit are only for the three layers of insulation that were placed on the attic floor and do not reflect any additional thermal resistance due to the layer that was placed between the roof truss supports and the aluminum roofing.) Annual field results show an average of R-17.0 $\left(\mathrm{R}_{\mathrm{SI}^{-}}-3.0\right)$ thermal resistance for the insulation in the standard unit and an insulation resistance of $\mathrm{R}-23.5\left(\mathrm{R}_{\mathrm{SI}}-4.4\right)$ for the upgraded unit, both greater than the rated values for 
these units.

Table 7. Variation of Actual Thermal Resistance (R-Value) of Roof Cavity Insulation on a Monthly Basis

\begin{tabular}{|c|c|c|c|c|c|c|}
\hline & \multicolumn{3}{|c|}{ Standard Unit (R-14) } & \multicolumn{3}{|c|}{ Upgraded Unit (R-28) } \\
\hline Month & $\begin{array}{c}\text { Field } \\
\left(\mathrm{hr} \bullet \mathrm{ft}^{2} \bullet{ }^{\circ} \mathrm{F} / \mathrm{Btu}\right)\end{array}$ & $\begin{array}{c}\mathrm{Lab} \\
\left(\mathrm{hr} \bullet \mathrm{ft}^{2} \bullet{ }^{\circ} \mathrm{F} / \mathrm{Btu}\right)\end{array}$ & $\begin{array}{l}\operatorname{Diff}^{(a)} \\
(\%)\end{array}$ & $\begin{array}{c}\text { Field } \\
\left(\mathrm{hr} \bullet \mathrm{ft}^{2} \bullet{ }^{\circ} \mathrm{F} / \mathrm{Btu}\right)\end{array}$ & $\begin{array}{c}\mathrm{Lab} \\
\left(\mathrm{hr} \bullet \mathrm{ft}^{2} \bullet{ }^{\circ} \mathrm{F} / \mathrm{Btu}\right)\end{array}$ & $\begin{array}{c}\operatorname{Diff}^{(a)} \\
(\%)\end{array}$ \\
\hline $06 / 95$ & 15.3 & 13.5 & 12.9 & 21.3 & 20.9 & 1.9 \\
\hline $07 / 95$ & & & & 20.2 & 20.8 & 2.8 \\
\hline $08 / 95$ & 13.5 & 13.4 & 0.7 & 21.1 & 20.8 & 1.4 \\
\hline $09 / 95$ & 16.2 & 13.6 & 18.6 & 21.6 & 21.0 & 2.5 \\
\hline $10 / 95$ & 17.4 & 13.9 & 25.6 & 23.8 & 21.3 & 12.1 \\
\hline $11 / 95$ & 16.9 & 14.2 & 19.6 & 25.7 & 21.6 & 18.7 \\
\hline $12 / 95$ & 18.0 & 14.4 & 24.6 & 24.3 & 21.7 & 11.7 \\
\hline $01 / 96$ & 17.7 & 14.5 & 22.3 & 25.1 & 21.8 & 15.4 \\
\hline $02 / 96$ & 19.9 & 14.1 & 41.3 & 25.8 & 21.6 & 19.6 \\
\hline 03/96 & 17.7 & 14.2 & 24.4 & 25.7 & 21.6 & 19.4 \\
\hline $04 / 96$ & 17.7 & 14.0 & 26.6 & 25.8 & 21.3 & 21.2 \\
\hline $05 / 96$ & 17.2 & 13.6 & 25.8 & 22.0 & 20.9 & 5.2 \\
\hline
\end{tabular}

(a) Difference $(\%)=\mid$ Lab-Field $\mid * 100 /$ Lab

As was shown in Fig. 2, one heat flux transducer was placed one $\mathrm{ft}$ from the edge of the exterior wall while the three remaining transducers were located along the center line of the roof assembly. Compression of an insulating material like fiberglass batts reduces the thickness which in turn reduces the thermal resistance. Yarbrough and Graves showed that in manufactured housing, the slope of the roof restricts space available for thermal insulation. ${ }^{3}$ By taking the ratio of heat flux from the edge transducer to the center-line transducer, the reduction of insulation thermal resistance can be determined. By knowing the distance of the edge heat flux transducer from the wall, 
the thickness of the insulation, and the roof slope, a calculation can be made to determine the amount of reduction of thermal resistance of the edge insulation. The height of the roof above the middle of the transducer in the standard unit is equal to $4.81 \mathrm{in}$. $(0.12 \mathrm{~m})$ and the thickness of the insulation above the middle of the transducer is $4.52 \mathrm{in} .(0.11 \mathrm{~m})$. This implies there is no compression of the edge insulation by the roof and therefore the ratio of the edge and center axis heat flux transducer measurements should be equal to 1.0. On an annual basis, the field data for the standard unit has a heat flux ratio from the edge to center transducers equal to 1.14. This small difference in the field and calculated heat flux ratios is attributed to wall edge effects. The wall edge effects are thermal bridges that exist at the eave edge where the roof trusses and ceiling joists are joined to the wall.

The height of the roof above the middle of the edge transducer in the upgraded unit is equal to $4.21 \mathrm{in}$. $(0.11 \mathrm{~m})$. The installed thickness of the insulation above the middle of the transducers located along the center of the attic space is about $7.4 \mathrm{in}$. $(0.19 \mathrm{~m})$ so the edge insulation must be compressed. By knowing the thickness of the compressed insulation and the mass per square foot, the density of the insulation can be calculated. The thermal conductivity of the compressed insulation is obtained from Eq. (3) using a temperature of $75^{\circ} \mathrm{F}\left(23.9^{\circ} \mathrm{C}\right)$ and the calculated density. [Note that the field compression is much greater than that used in the laboratory to produce the data that was used to derive Eq. (3)]. The thermal resistance of the compressed insulation is the measured thickness divided by the thermal conductivity calculated from Eq. (3). The thermal resistance for the center transducer insulation is calculated by the same procedure. If the temperature difference across the insulation were equal in both cases, the ratio of the thermal resistances would be equal to the ratio of the heat fluxes. The ratio of the heat flux measured by the edge transducer to the heat flux measured by the center axis transducer in the upgraded unit would equal 1.31 under this condition. However, the temperature difference across the insulation is not equal in both cases. The edge insulation is not only compressed, but is in direct contact with the roof surface, and thus directly linked with the external air temperature (via conduction through the roof and external convective heat transfer conditions). The center insulation is exposed to an 
enclosed air space at a buffered temperature and experiences natural convection heat transfer to this space. The field data show the combined effect of these factors. On an annual basis, field data show that the upgraded unit has a heat flux ratio from the edge to center axis transducers equal to 1.50 .

By examination of Figure 8, a significant difference in ratios exists between the two manufactured home units. These results show that a considerable amount of reduction in thermal resistance is taking place in the edges of the roof cavity for the upgraded unit. The month of November gave an anomalous result in that the standard unit heat flux ratio was slightly greater than the upgraded unit.

Since there is no compression of the insulation in the standard unit, the average of the four heat flux transducers was used to represent a heat flux for the total insulation area. Because of the insulation compression in the upgraded unit, a different approach was taken to determine the heat flux for the total insulation area. The edge heat flux transducer represents $4 \%$ of the total ceiling area. The average of the remaining three center axis heat flux transducers contributed $96 \%$ of the total ceiling area. The average

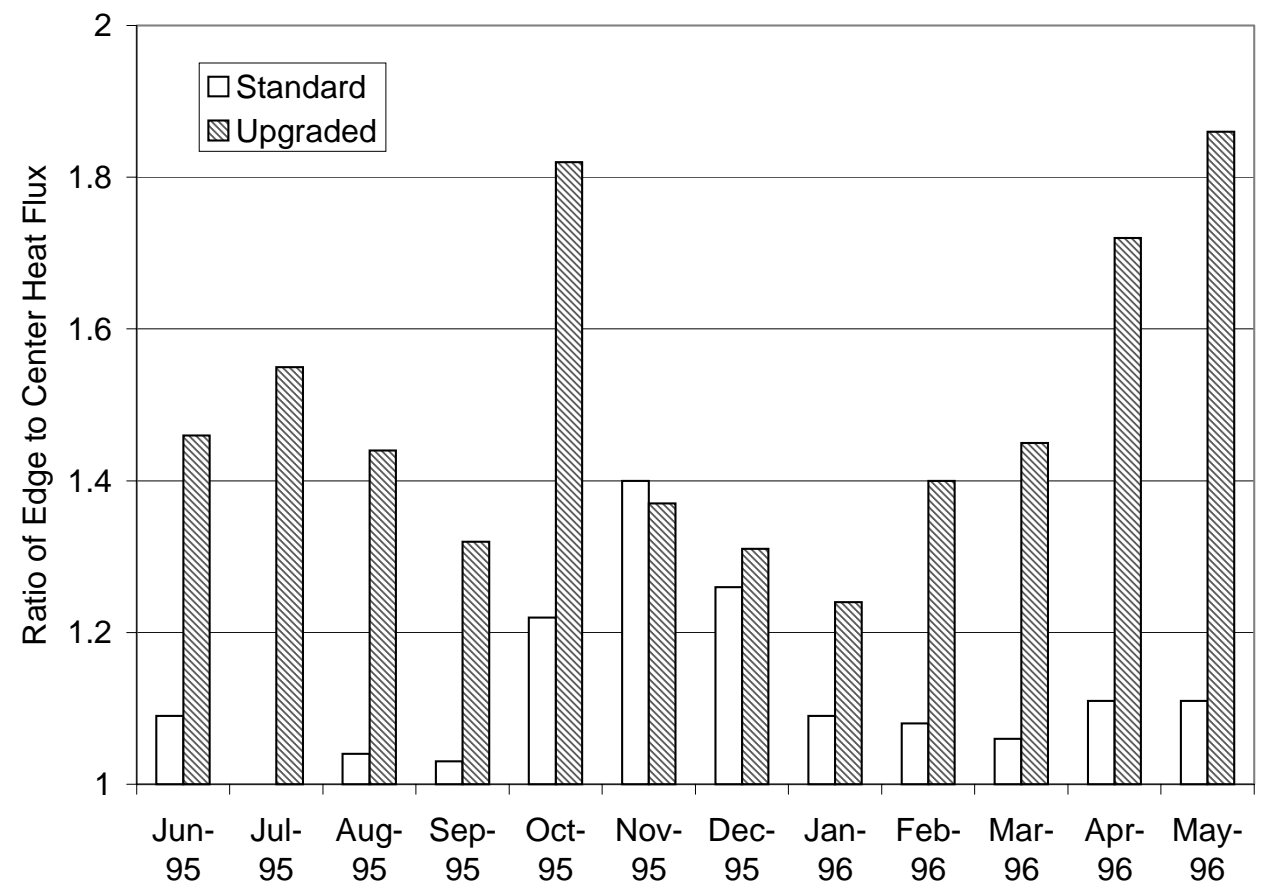

Figure 8. Ratio of edge to center heat flux transducer energy gain/loss. 
of the three center axis heat flux transducers is multiplied by 0.96 and the edge heat flux transducer is multiplied by 0.04 . The sum of these products gives a weighted average for the total insulation area.

The total heat flowing through the insulation, excluding the wood joists, is then calculated by the product of the weighted average heat flux of the insulation area by the insulation area using Eq. (9).

$$
q_{\text {insulation }}=q_{\text {insulation }}^{\prime} * A
$$

The total insulation heat loss or gain for a period of $\mathrm{t}$ hours was calculated by using Eq. (10).

$$
Q_{\text {insulation }}=q_{\text {insulation }} * t
$$

\subsubsection{Field Data Analysis - Total Energy Consumption}

The roof assemblies of the manufactured home units were constructed of wood trusses and insulated with layers of nominal R-7 ( $\left.\mathrm{R}_{\mathrm{SI}}-1.2\right)$ fiberglass batts. Wood joists were used as the support for the ceiling gypsum board and the fiberglass insulation. The fiberglass batts were placed between these wood joists. The fraction of ceiling area occupied by the wood joists was calculated by dividing the area of the wood attached to the ceiling by the total ceiling area. Each manufactured home unit contains 27 wood joists that are $0.125 \mathrm{ft}$ wide by $14.0 \mathrm{ft}$ long by $1.5 \mathrm{in}$. thick $(0.038 \mathrm{~m}$ by $4.27 \mathrm{~m}$ by $0.04 \mathrm{~m})$. Total area of the ceiling of one unit is $728.0 \mathrm{ft}^{2}\left(67.7 \mathrm{~m}^{2}\right)$. Therefore, the fraction of ceiling area covered by wood joists is 0.065 . The fraction of ceiling area covered by insulation batts is 0.935 . In order to calculate an overall thermal resistance of the attic floor, the thermal resistance of the wood joists and the thermal resistance of the insulation must be known. This overall attic floor thermal resistance was calculated using a seriesparallel heat-flow equation from the ASHRAE Handbook of Fundamentals that reduces to Eq. (11) when the area fractions described above are used. ${ }^{2}$ 


$$
\frac{1}{R_{\text {atticfloor }}}=\frac{0.935}{R_{\text {insulation }}}+\frac{0.065}{R_{\text {wood }}}
$$

By calculating $\mathrm{R}_{\text {attic floor }}$ from Eq. (11), a series of calculations can then be made to determine the fraction of the total ceiling heat flow that comes through the roof cavity insulation. More heat will flow through the wood joists per square foot of area than the insulation batts due to the lower thermal resistance of the wood members. Heat flux transducers were placed between the ceiling and the insulation batt and, therefore, measured only the heat loss or gain through the insulation. The fraction of the total heat flow that is transported by the insulation was calculated using Eq. (12).

$$
f_{\text {insulation }}=\frac{0.935}{R_{\text {insulation }}} * R_{\text {atticfloor }}
$$

Using nominal R-values for the insulation and wood produces a $\mathrm{f}_{\text {insulation }}$ of 0.6 for the standard unit and 0.5 for the upgraded unit. In other words, 40 to $50 \%$ of the total ceiling heat flux is going through the wood joists in this arrangement. The soft pine wood used to construct the trusses has an R-value of approximately $1.0 \mathrm{hr} \bullet \mathrm{ft}^{2}{ }^{\circ} \mathrm{F} / \mathrm{Btu}$ per in. of thickness, or R-1.5 ( $\left.\mathrm{R}_{\mathrm{SI}^{-}}-0.2\right)$.

An overall attic floor thermal resistance $\left(\mathrm{R}_{\text {attic floor }}\right)$ was then calculated using Eq. (11) and the field-measured data for the fiberglass insulation. The calculated and fieldmeasured attic floor thermal resistances are compared in Table 8. The wood trusses cause a significant reduction in the overall performance of the roof cavity. By examination of these results, larger reductions in the field-measured overall thermal resistances $\left(\mathrm{R}_{\text {Total }}\right)$ exist for the upgraded unit than for the standard unit. Annual results showed overall thermal resistances of R-10.2 ( $\left.\mathrm{R}_{\mathrm{SI}}-1.8\right)$ for the standard manufactured home unit and an overall thermal resistance of $\mathrm{R}-12.0\left(\mathrm{R}_{\mathrm{SI}}-2.1\right)$ for the upgraded manufactured home unit.

Calculations were made to determine the increase of the overall thermal resistance for both manufactured home units if the thermal resistance of the wood joists were to be increased to R-3.5( $\left.\mathrm{R}_{\mathrm{SI}^{-}}-0.6\right)$. The thermal resistance of this portion of the attic floor could 
be increased by placing any type of insulating material on top of the joists or by increasing the wood joist thickness to $3.5 \mathrm{in}$. $(0.09 \mathrm{~m})$. These results are also included in Table 8 and show that a significant increase in the overall thermal resistance would result from increasing the thermal resistance of the joist area.

Table 8. Overall Attic Floor Thermal Resistances of Standard and Upgraded Roof Assemblies with 1.5 in. and 3.5 in. Wooden Joists in Parallel Heat Flow - 1995-1996 Data *

\begin{tabular}{|l|c|c|c|c|l|c|}
\hline & \multicolumn{3}{|c|}{ Standard Unit } & \multicolumn{3}{c|}{ Upgraded Unit } \\
\hline & $\begin{array}{c}\text { Field } \\
\text { Monsulation } \\
\text { only) }\end{array}$ & 1.5 in. & 3.5 in. & $\begin{array}{c}\text { Field } \\
\text { insulation } \\
\text { only) }\end{array}$ & 1.5 in. & 3.5 in. \\
\hline June & 15.3 & 9.6 & 12.5 & 21.3 & 11.5 & 16.0 \\
\hline July & & & & 20.2 & 11.2 & 15.4 \\
\hline August & 13.5 & 8.9 & 11.4 & 21.1 & 11.4 & 15.9 \\
\hline September & 16.2 & 9.9 & 13.1 & 21.6 & 11.5 & 16.1 \\
\hline October & 17.4 & 10.3 & 13.9 & 23.8 & 12.1 & 17.3 \\
\hline November & 16.9 & 10.2 & 13.6 & 25.7 & 12.5 & 18.2 \\
\hline December & 18.0 & 10.5 & 14.2 & 24.3 & 12.2 & 17.5 \\
\hline January & 17.7 & 10.4 & 14.0 & 25.1 & 12.4 & 17.9 \\
\hline February & 19.9 & 11.1 & 15.3 & 25.8 & 12.6 & 18.3 \\
\hline March & 17.7 & 10.4 & 14.0 & 25.7 & 12.6 & 18.2 \\
\hline April & 17.6 & 10.4 & 14.0 & 25.8 & 12.6 & 18.2 \\
\hline May & 17.2 & 10.2 & 13.7 & 22.0 & 11.7 & 16.4 \\
\hline
\end{tabular}

*The units for the thermal resistances in this table are $\mathrm{h} \bullet \mathrm{ft}^{2} \bullet{ }^{\circ} \mathrm{F} / \mathrm{Btu}$.

Total heat flow across the ceiling $\left(\mathrm{Q}_{\text {ceiling }}\right)$ is calculated from the total heat flux of the insulation system $\left(\mathrm{Q}_{\text {insulation }}\right)$ divided by the fraction of the total heat flow that is transported by insulation [ $\mathrm{f}_{\text {insulation }}$ from Eq. (12)] as shown by Eq. (13).

$$
Q_{\text {ceiling }}=\frac{Q_{\text {insulation }}}{f_{\text {insulation }}}
$$


This calculated total ceiling heat flow contains both insulation and wood joist contributions.

Both of the manufactured home units used in this project were heated and cooled with electric heat pumps. Coefficient of performance for both heat pumps were calculated for several months of operation. A coefficient of performance is defined by Eq. (14).Where $\left|Q_{1}\right|$ is the absolute value of the heat transferred to the higher temperature

$$
C O P=\frac{\text { Refrigerant Effect }}{\text { Net Work Input }}=\frac{\left|Q_{2}\right|}{\left|Q_{1}\right|-\left|Q_{2}\right|}
$$

sink, and $\mathrm{Q}_{2} \mid$ is the absolute value of the heat transferred from the lower temperature source. For example, if a heat pump has a coefficient of performance equal to 3.0, for every one kilowatt-hour of energy input into the heat pump, there will be three kilowatthours of output due to energy from the refrigerant thermodynamic cycle. The manufacturer of the heat pumps provided coefficients of performance of 1.97 and 3.0 at outdoor air temperatures of 17 and $47^{\circ} \mathrm{F}$ (-8.3 and $\left.8.3^{\circ} \mathrm{C}\right)$, respectively. These two points were used to obtain a linear expression which is shown in Eq. (15). Average outdoor air temperatures for each month were provided by an on-site weather station. Using the monthly average air temperature, the coefficient of performance for each month of heating was calculated using Eq. (15).

$$
C O P=0.0343 * \bar{T}_{\text {air }}+1.39
$$

The electrical energy inputs to the heat pump and resistive heater were measured separately. The fraction of the total electrical energy for the heat pump and resistive heater were calculated. The heat pump fraction is multiplied by the coefficient of performance and the resistive heating fraction is multiplied by a coefficient of performance of 1.0. These products were summed to give a monthly heat pump coefficient of performance adjusted for resistive heating. Total thermal energy input 
$\left(\mathrm{Q}_{\text {total }}\right)$ to each manufactured home is calculated by the product of the total electrical energy ( $\left.\mathrm{E}_{\text {total }}\right)$ (heat pump and resistive) and the coefficient of performance (COP) for the heat pump and resistive heater combined. The total electrical energy $\left(\mathrm{E}_{\text {total }}\right)$ is converted from kilowatt-hours to BTUs by multiplying by 3412. Eq. (16) shows the calculation of $\mathrm{Q}_{\text {total }}$.

$$
Q_{\text {total }}=E_{\text {total }} * C O P
$$

The fractional amount of total input energy $\left(\mathrm{Q}_{\text {total }}\right)$ that moved through the ceiling alone $\left(\mathrm{Q}_{\text {ceiling }}\right)$ is calculated from Eq. (17).

$$
f_{\text {ceiling }}=\frac{Q_{\text {ceiling }}}{Q_{\text {total }}}
$$

Five separate calculations using Eq. (17) were performed to determine the quantity of the total energy input to the manufactured home that was transported through the ceiling. In each calculation, the present hour temperature difference determined by subtracting the temperature measured on the ceiling side from the temperature measured on top of the insulating batt is subtracted from the previous hour temperature difference. If this insulation temperature difference change was greater than $1^{\circ} \mathrm{F}\left(0.6^{\circ} \mathrm{C}\right)$, the heat flux measurement was discarded for that hour interval. Calculations were also made at insulation temperature difference changes of $3^{\circ} \mathrm{F}, 5^{\circ} \mathrm{F}, 7^{\circ} \mathrm{F}$, and $10^{\circ} \mathrm{F}(1.7,2.8,3.9$, and $5.6^{\circ} \mathrm{C}$ ). By making these calculations, it was possible to determine if small insulation temperature variations affected the calculated heat loss or gain through the ceiling. Final results showed that only a $2 \%$ difference in the overall fraction of ceiling energy loss was encountered when all heat fluxes were kept in the calculation.

Calculations were performed to determine the quantity of the total heat input into the manufactured home that was lost or gained through the ceiling. The purpose for this calculation was to determine if a significant fraction of the total heat input to the manufactured home was being lost or gained through the ceiling. These calculations were made using Eq. 17. Figure 9 shows the monthly fractional results for each unit. Table 9 gives the results in tabular form. 


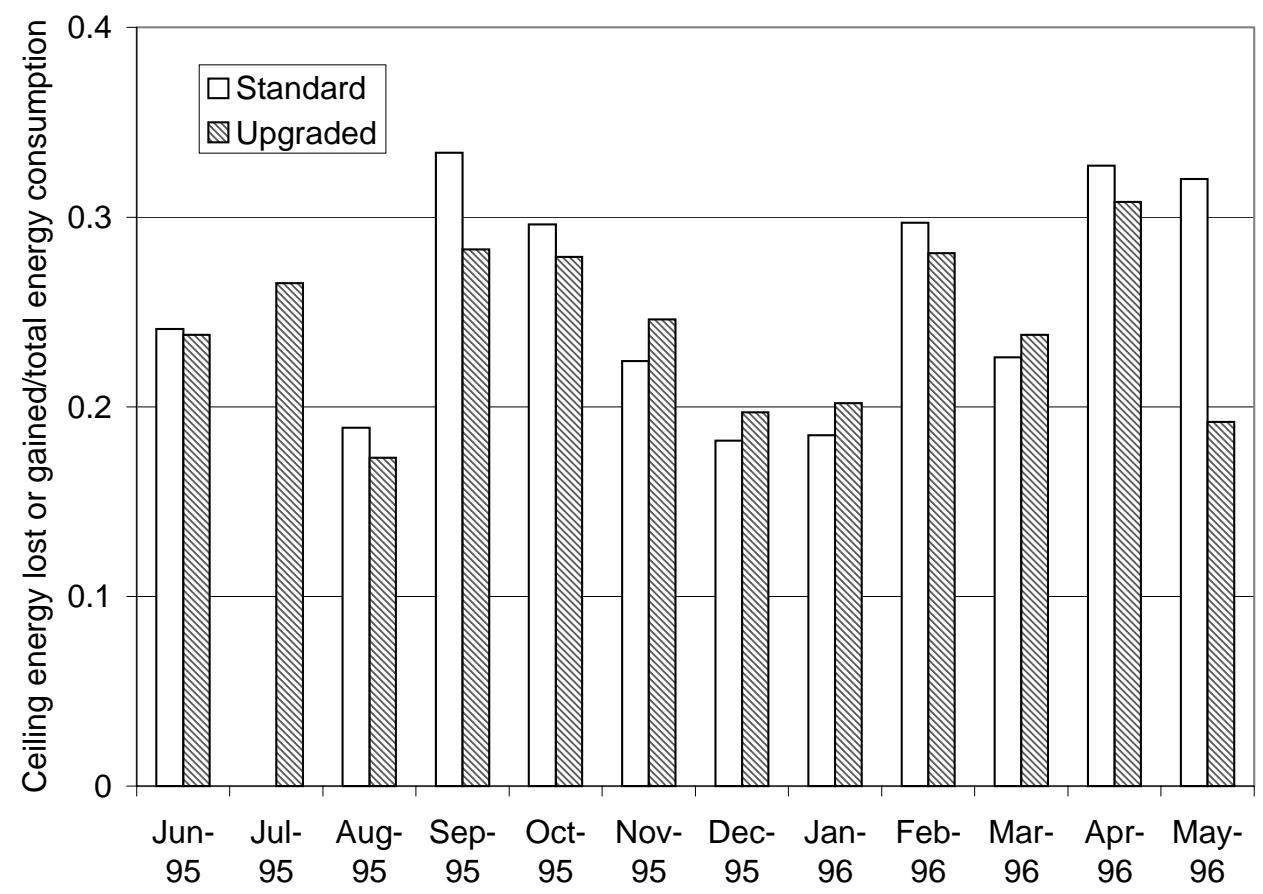

Figure 9. Fraction of total energy input into test homes that is lost or gained through the ceiling - 1995-1996 data.

Table 9. Fraction of Total Energy Input into Test Homes that is Lost or Gained through the Ceiling - 1995-1996 Data

\begin{tabular}{|c|c|c|c|c|c|}
\hline & $\begin{array}{l}\text { Standard } \\
\text { Unit }\end{array}$ & $\begin{array}{l}\text { Upgraded } \\
\text { Unit }\end{array}$ & & $\begin{array}{l}\text { Standard } \\
\text { Unit }\end{array}$ & $\begin{array}{l}\text { Upgraded } \\
\text { Unit }\end{array}$ \\
\hline June & 0.241 & 0.238 & December & 0.182 & 0.197 \\
\hline July & -- & 0.265 & January & 0.185 & 0.202 \\
\hline August & 0.189 & 0.173 & February & 0.297 & 0.281 \\
\hline September & 0.334 & 0.283 & March & 0.226 & 0.238 \\
\hline October & 0.296 & 0.279 & April & 0.327 & 0.308 \\
\hline November & 0.224 & 0.246 & May & 0.320 & 0.192 \\
\hline $\begin{array}{l}\text { Annual } \\
\text { Average }\end{array}$ & 0.240 & 0.220 & & & \\
\hline
\end{tabular}


The highest fractional results occurred in April, May, September, and October. This was due to the air temperature fluctuations from warm days to cool nights. After applying the fractional results for each month to that month's energy use, the annual fraction for the standard unit was 0.240 and for the upgraded unit was 0.220 .

\subsubsection{Computational Fluid Dynamics Models}

Another way to consider the complexities of heat flow through the attic is to use a computational fluid dynamics model. This method explicitly recognizes the effect of air movement within the closed attic space on heat transfer through the attic configuration. Using CFX-4.2 Solver, simplified two-dimensional models of the attic spaces were first constructed to correspond with the physical geometry of the attics described in Sect. 2.1. The grid applied to this space is shown in Figs. 10 and 11. The computational models used a plane of symmetry down the centerline of the attic, so these grids represent onehalf of the triangular attic space. The radiation heat transfer model is one included within the CFX code and is a discrete transfer method developed by Shah. ${ }^{4}$ The equations solved at each grid node are the incompressible Navier-Stokes equations with a Boussinesq approximation to account for buoyancy. A k-epsilon turbulence model was used.

These two-dimensional models do not include the wooden attic joists, but are useful for bench marking the computer model and for determining the necessary grid spacing. Table 10 summarizes many of the assumptions used within the computer models. The boundary conditions were selected to match those of a relatively cold winter night, such as several nights that occurred during January 1997.

For comparison, several time periods were chosen from the weather data that met the criteria of relatively stable outdoor temperature (because the computational model assumes steady-state conditions) and with no incident solar radiation (because that was not included in the model). Figure 12 shows the air temperature measured during the selected time periods. The overall attic R-values for those time periods were calculated using the corresponding heat flux meter data and the temperature difference between the 


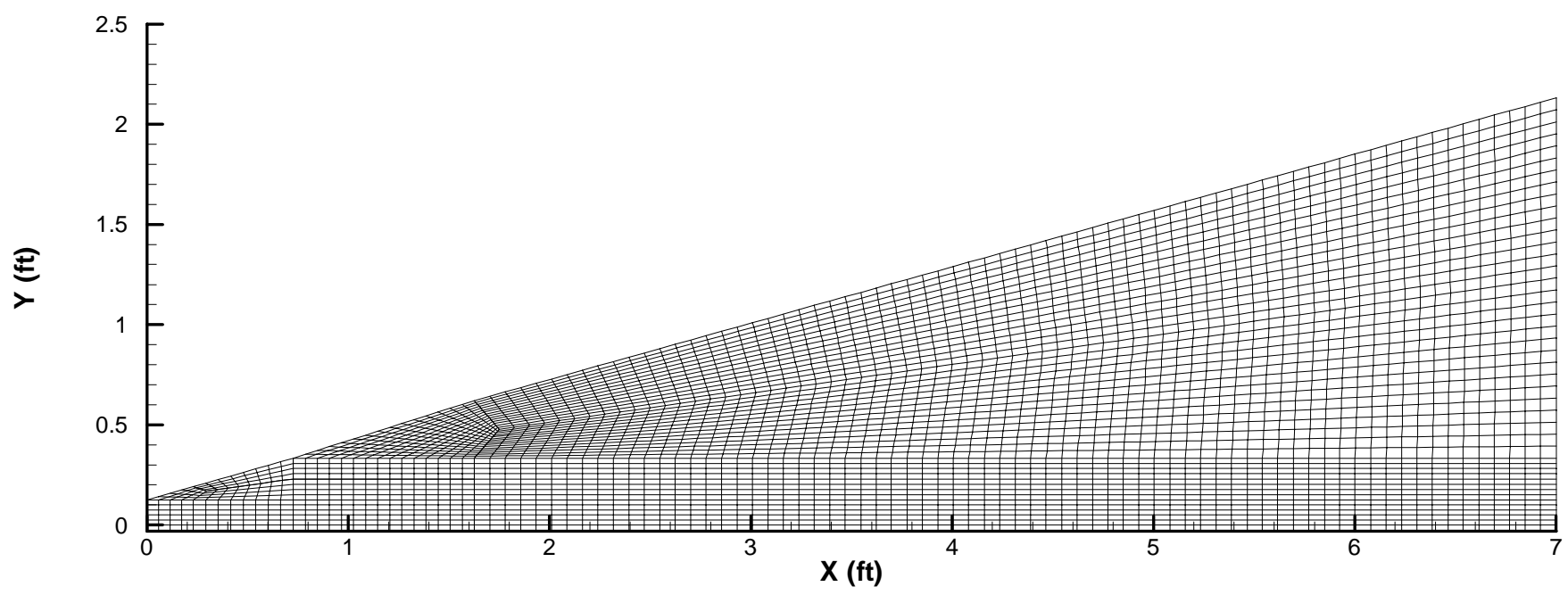

Figure 10. Grid used to calculate heat and mass flows for the standard insulation attic space.

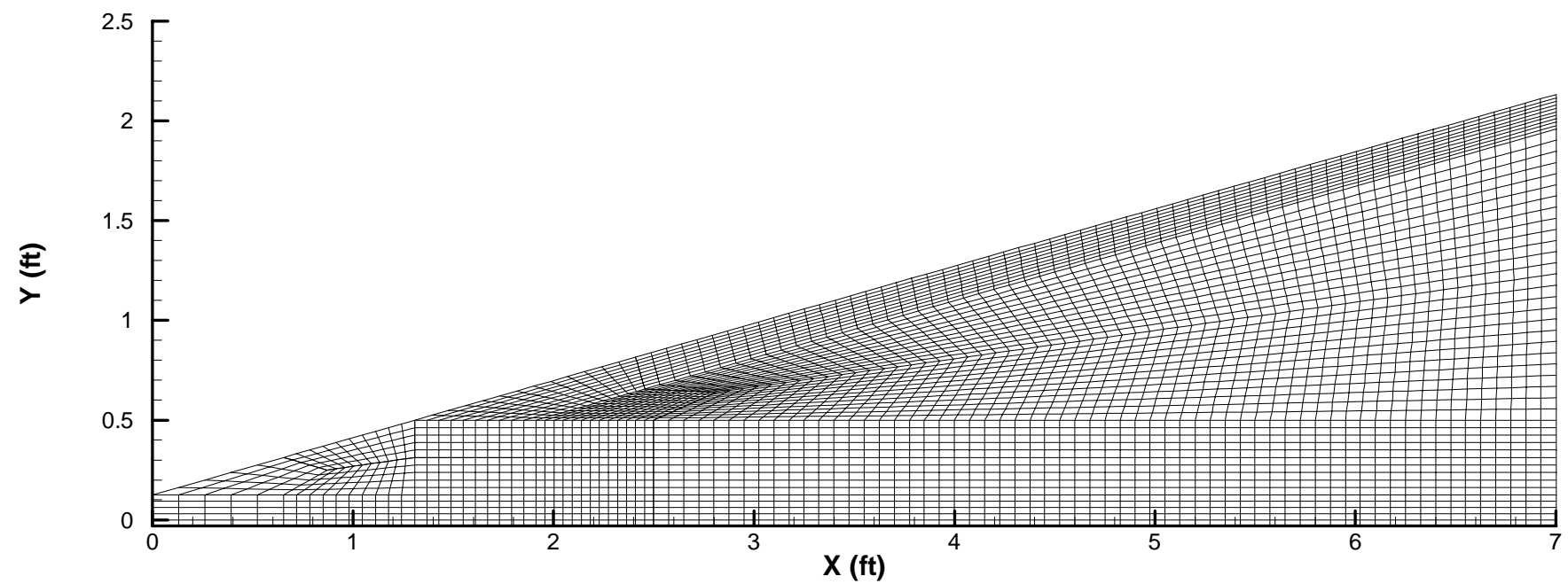

Figure 11. Grid used to calculate heat and mass flows for the upgraded insulation attic space. 
Table 10. Values of Parameters Used in Computational Fluid Dynamics Model

\begin{tabular}{|l|c|c|}
\hline \multirow{2}{*}{ Air Temperature $\left({ }^{\circ} \mathrm{F}\right)$} & Inside & 70 \\
\cline { 2 - 3 } & Outside & 25 \\
\hline \multirow{2}{*}{$\begin{array}{l}\text { Air Film Resistance } \\
\left(\mathrm{h}-\mathrm{ft}^{2}{ }^{\circ} \mathrm{F} / \mathrm{Btu}\right)\end{array}$} & Inside & 0.61 \\
\hline & Outside & 0.17 \\
\cline { 2 - 3 } $\begin{array}{l}\text { Thermal Conductivity } \\
\left(\mathrm{Btu} / \mathrm{h}-\mathrm{ft}-{ }^{\circ} \mathrm{F}\right)\end{array}$ & Gypsum board & 0.1335 \\
\cline { 2 - 3 } & Insulation & 0.0238 \\
\hline
\end{tabular}

outdoor temperatures and an indoor temperature of $70^{\circ} \mathrm{F}\left(21^{\circ} \mathrm{C}\right)$. This value is the air-toair thermal resistance, that is, it includes the effect of indoor and outdoor surface film resistances and all the materials and air space within the attic construction, not just the insulation. For this calculation, the heat flux meter data was treated as described in Sect. 3.2, that is, (1) for the standard unit the average of all four meters was used and (2) for the upgraded unit, the average of the three central transducers was multiplied by 0.96 and

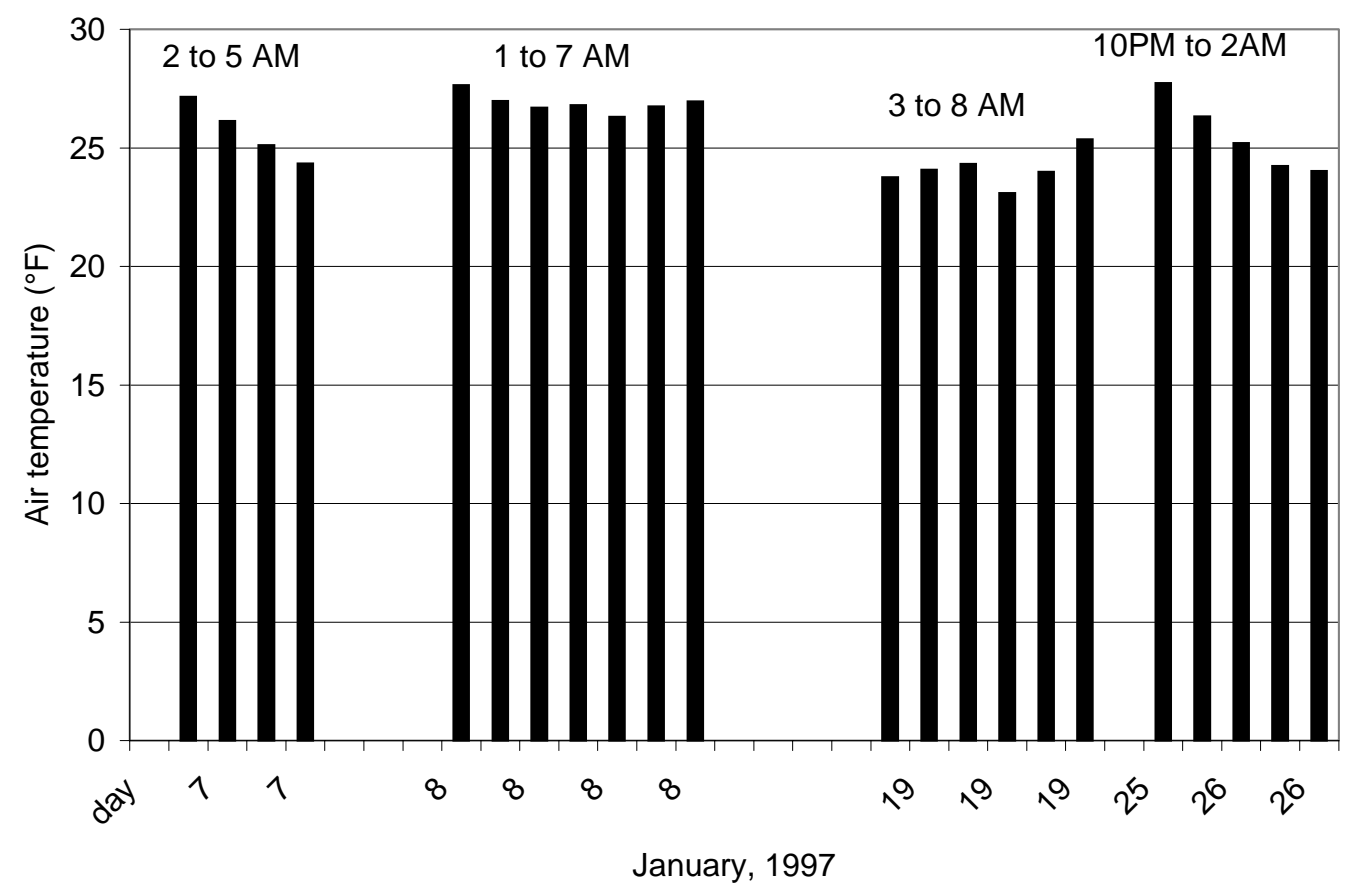

Figure 12. Air temperatures measured during January, 1997 for time periods used to bench mark two-dimensional computational fluid dynamics model. 


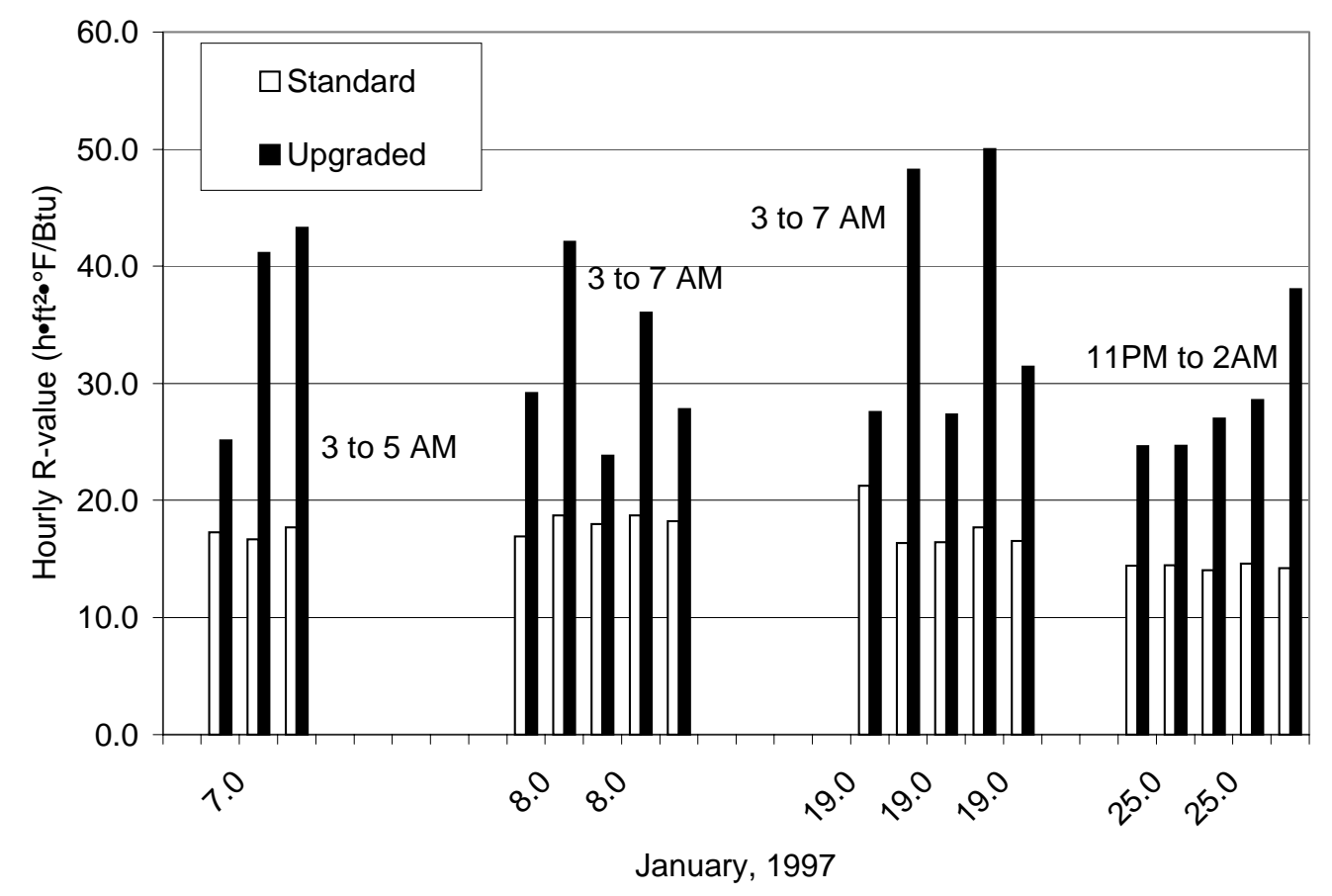

Figure 13. Overall attic space R-values (including indoor and outdoor surface air resistances) calculated using measured heat fluxes and outdoor temperatures for comparison periods during January, 1997

added to 0.04 times the value from the edge transducer. The results of this calculation are shown in Fig. 13.

The average $\mathrm{R}$-value for the standard unit for this period was $16.8\left(\mathrm{R}_{\mathrm{SI}^{-}}-2.9\right)$ with a standard deviation of $2.7 \%$. For comparison, the two-dimensional computational model predicted R-15.2 $\left(\mathrm{R}_{\mathrm{SI}^{-}}-2.6\right)$ for the standard unit, or about $10 \%$ less.

The upgraded unit has lower heat flux values, leading to greater variability in the data, as shown by Fig. 13. The mean of the values shown is $\mathrm{R}-33.1\left(\mathrm{R}_{\mathrm{SI}}-5.7\right)$, with a large standard deviation of $25 \%$. For comparison, the two-dimensional computational fluid dynamics model predicted R-23.7 $\left(\mathrm{R}_{\mathrm{SI}^{-}}-4.1\right)$ for the upgraded unit. Although this is $28 \%$ less than the mean measured value, it is very close to the values recorded for many of the selected time periods, again as shown in Fig. 13. Remember that these values are air-toair thermal resistances that include the effect of surface film resistances and all the materials and air space within the attic construction, not just the insulation. 
Computational models are also useful for expanding our understanding of the various heat transfer mechanisms at work in the attic space. Although the various heat transfer modes are highly interlinked, it is instructive to look at the effect of "turning off" one or more modes to see the effect on the total heat flux. This exercise is explored in Table 11. The effectiveness of still air as an insulator is demonstrated in the conduction only model, where the R-value of the standard model is greater than that of the upgraded model because the still air is less conductive than the insulation. When convection is allowed, the value of the insulation becomes apparent. While adding radiation heat transfer to the model, the effect of reflective surfaces was examined. The emissivity of the surfaces would be low for reflective surfaces such as polished aluminum ( 0.05 was used for these cases) and higher for dull surfaces, such as the insulation attached to the underside of the roof in the upgraded unit. The reflective surface has a relatively small impact under the winter condition, i.e. heat flow up, modeled here. The effect would be greater under heat flow down, or summer, conditions.

Table 11. Effect of Varying Heat Transfer Parameters on Heat Flow Through the Attic, Two-Dimensional Model*

\begin{tabular}{|l|c|c|}
\hline \multirow{2}{*}{$\begin{array}{l}\text { Modeled Heat Transfer Mechanism(s) in } \\
\text { Attic Space }\end{array}$} & \begin{tabular}{c} 
Standard \\
R-Value \\
\cline { 2 - 3 }
\end{tabular} & $\begin{array}{c}\text { Upgraded } \\
\left(\mathrm{h}-\mathrm{ft}^{2}-{ }^{\circ} \mathrm{F} / \mathrm{Btu}\right)\end{array}$ \\
\hline Conduction only & 32.63 & 32.29 \\
\hline Conduction + Convection & 16.64 & 24.74 \\
\hline $\begin{array}{l}\text { Conduction }+ \text { Convection }+ \text { Radiation } \\
\varepsilon_{\text {attic floor }}=0.8, \varepsilon_{\text {attic ceiling }}=0.8\end{array}$ & 15.20 & 23.69 \\
\hline $\begin{array}{l}\text { Conduction }+ \text { Convection }+ \text { Radiation } \\
\varepsilon_{\text {attic floor }}=0.8, \varepsilon_{\text {attic ceiling }}=0.05\end{array}$ & 16.42 & 24.45 \\
\hline
\end{tabular}

*Average R-value, from the two-dimensional model and therefore not corrected for trusses.

The air flow patterns for both units (from two-dimensional models including all three heat transfer modes) are shown in Figs. 14 and 15. Note that the additional insulation in the upgraded model not only reduces the conductive heat transfer, but also 


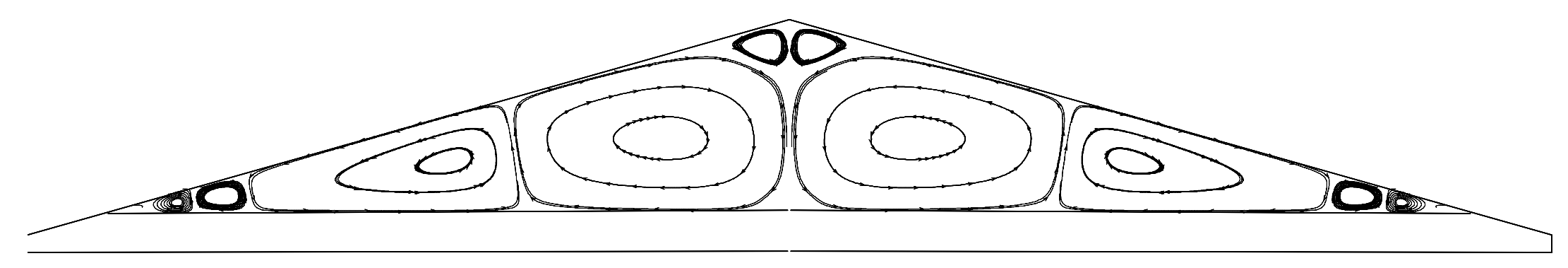

Figure 14. Air flow patterns predicted by computational model in standard insulation attic space.

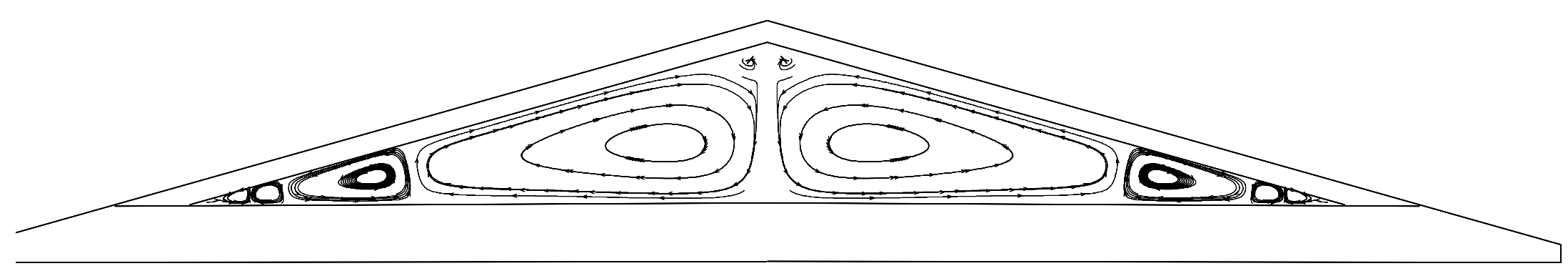

Figure 15. Air flow patterns predicted by computational model in upgraded insulation attic space. 


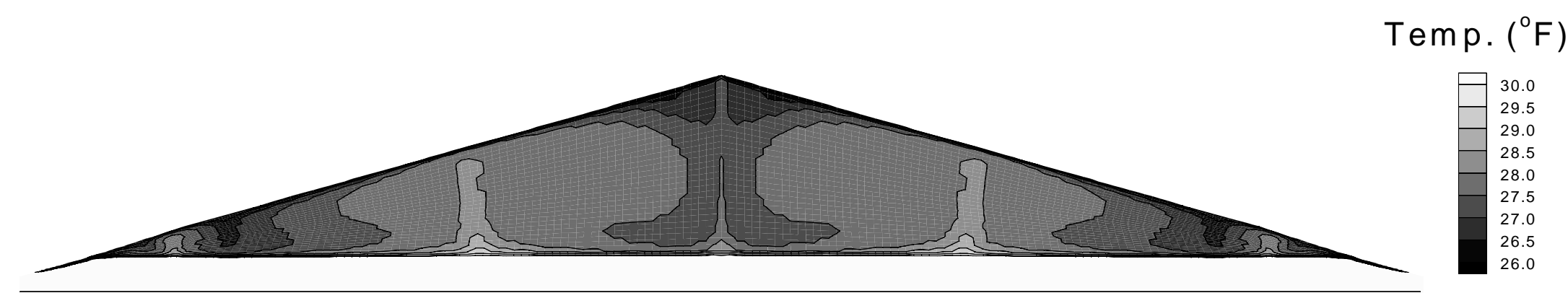

Figure 16. Temperature distributions predicted by computational model in standard insulation attic space.

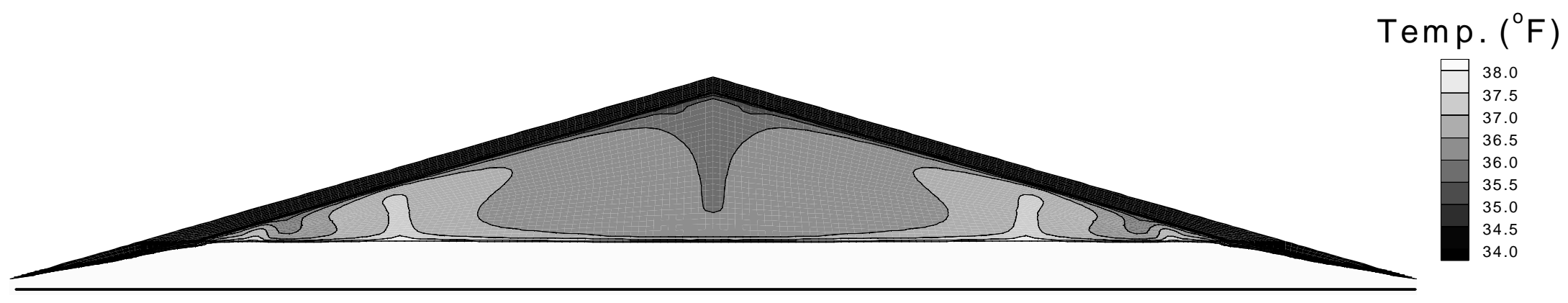

Figure 17. Temperature distributions predicted by computational model in upgraded insulation attic space. 
reduces the height of the air space within the attic. This reduced height in turn reduces the natural convection driving force. The effect of the reduced convective currents is apparent in the temperature profiles within the attic spaces, as shown in Figs. 16 and 17. The colder outside temperatures penetrate much deeper into the attic air space with the air circulation for the standard unit (Figs. 14 and 16) than for the upgraded unit (Figs. 15 and 17). The effect of the additional batt of insulation placed against the roof membrane is also illustrated in these temperature profiles, where the coldest attic air temperature is $34^{\circ} \mathrm{F}\left(1^{\circ} \mathrm{C}\right)$ in the upgraded unit, compared to $26^{\circ} \mathrm{F}\left(-3^{\circ} \mathrm{C}\right)$ in the standard unit. Remember that an outdoor air temperature of $25^{\circ} \mathrm{F}\left(-4^{\circ} \mathrm{C}\right)$ was used for both models. In the two manufactured homes tested here, the insulation was properly installed between and adjacent to the wood joists. However, sometimes when batt insulation is used, gaps can occur between the wood trusses and the insulation batts, allowing air to travel all the way down to the gypsum board surface of the attic floor. To explore this effect, computational models were created to reflect two extreme conditions. The first model represents poorly installed batt insulation with air gaps on each side of the joist and with no insulation above the joist. For comparison, the second model represents a 'perfect' insulation installation with no air gaps and with the joists fully covered. Examining this effect required a three-dimensional computational model. For both models, a plane of symmetry below the ridge line of the roof was used as for the two-dimensional model. Two additional planes of symmetry were also used to bound the computational domain. The first is parallel to the wood joist and travels down the center of a joist. The second is also parallel to the wood joist but travels down the centerline between two adjacent joists. These planes and the geometry used for the two comparison models are shown on Fig. 18. Both of these models reflect the standard insulation unit but modified to include either an air gap on each side of the joist or to include insulation covering the joist. The grid used for these models is shown in Figs. 19 and 20. Figure 20 is taken from a slice near the centerline of the attic and perpendicular to the wood joist. Note that the grid is somewhat coarser than that used for the two-dimensional model, although the total number of grid points is of course much greater. The air circulation within the gap combined with the uncovered wood joist increases the overall heat flux by 
almost $60 \%$, decreasing the overall thermal resistance from the 'perfect' case's R-14.8 to $\mathrm{R}-9.3\left(\mathrm{R}_{\mathrm{SI}^{-}}-2.5\right.$ to $\left.\mathrm{R}_{\mathrm{SI}^{-}}-1.6\right)$. Note that the value for the corresponding two-dimensional model without gaps or joists was $\mathrm{R}-15.2\left(\mathrm{R}_{\mathrm{SI}}-2.6\right)$. This difference of $3 \%$ is attributable to the inclusion of the wood joist and to the slightly coarser grid used in the threedimensional model. This calculation demonstrates the importance of careful installation procedures. Indeed, many of the later manufactured home models produced by this manufacturer use loose-fill insulation to preclude such gaps and to fully cover the wood joists.
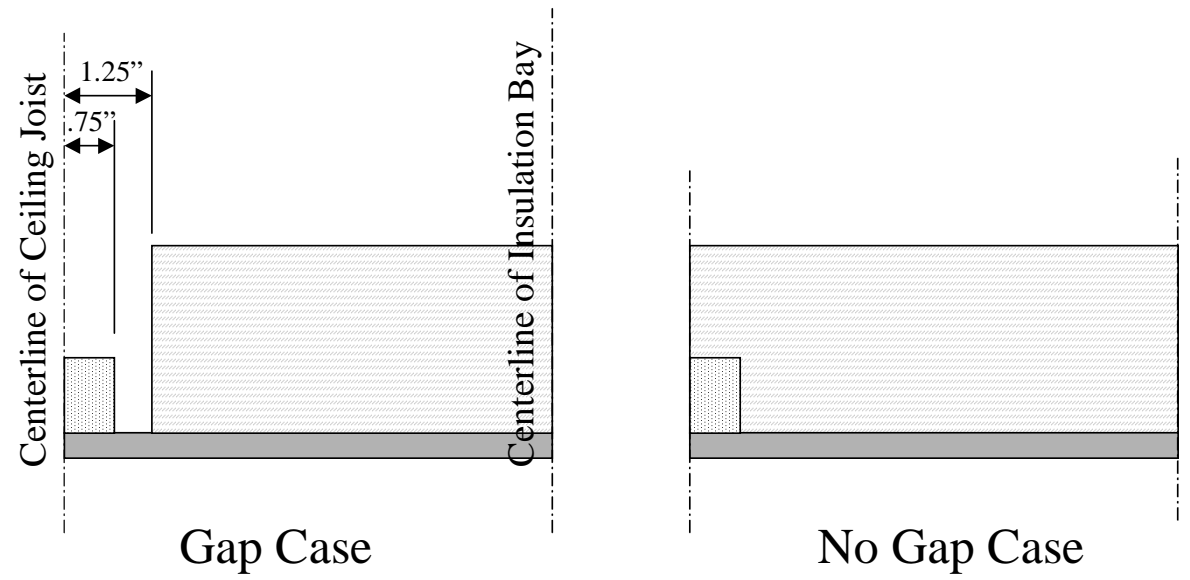

Figure 18. Geometry used in three-dimensional computational models of attic space with and without air gaps parallel to each joist. 


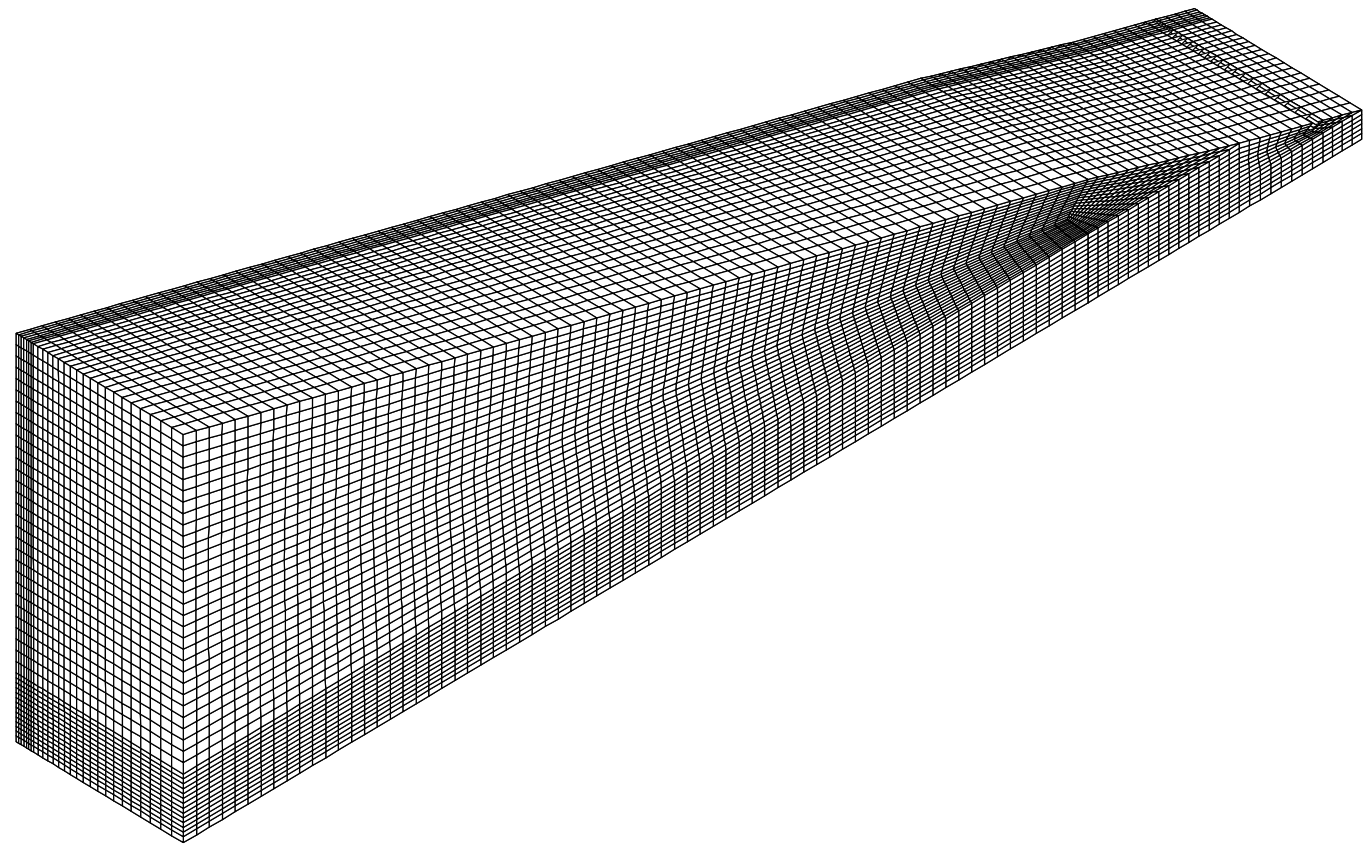

Figure 19. Grid used to calculate heat and mass flows for the three-dimensional model of the standard insulation attic space.

\subsubsection{Effect of Air Infiltration on Energy Consumption}

Air infiltration is a major contributor to energy loss or gain in buildings. With the use of a blower door, fan depressurization tests were conducted on both manufactured homes to determine the air infiltration rates. ${ }^{5}$ Calculations were made to determine the number of air changes per hour $(\mathrm{ACH})$ for each manufactured home. The volumetric flow rate of air across the building envelope was measured as a function of the pressure difference across the envelope. An equation relating $\log \mathrm{V}$ with $\log \Delta \mathrm{P}$ was derived from the data. A volumetric flow rate of air across the exterior envelope at a pressure of 50 pascals (ACH50) was then determined from the data. The volume of the manufactured 


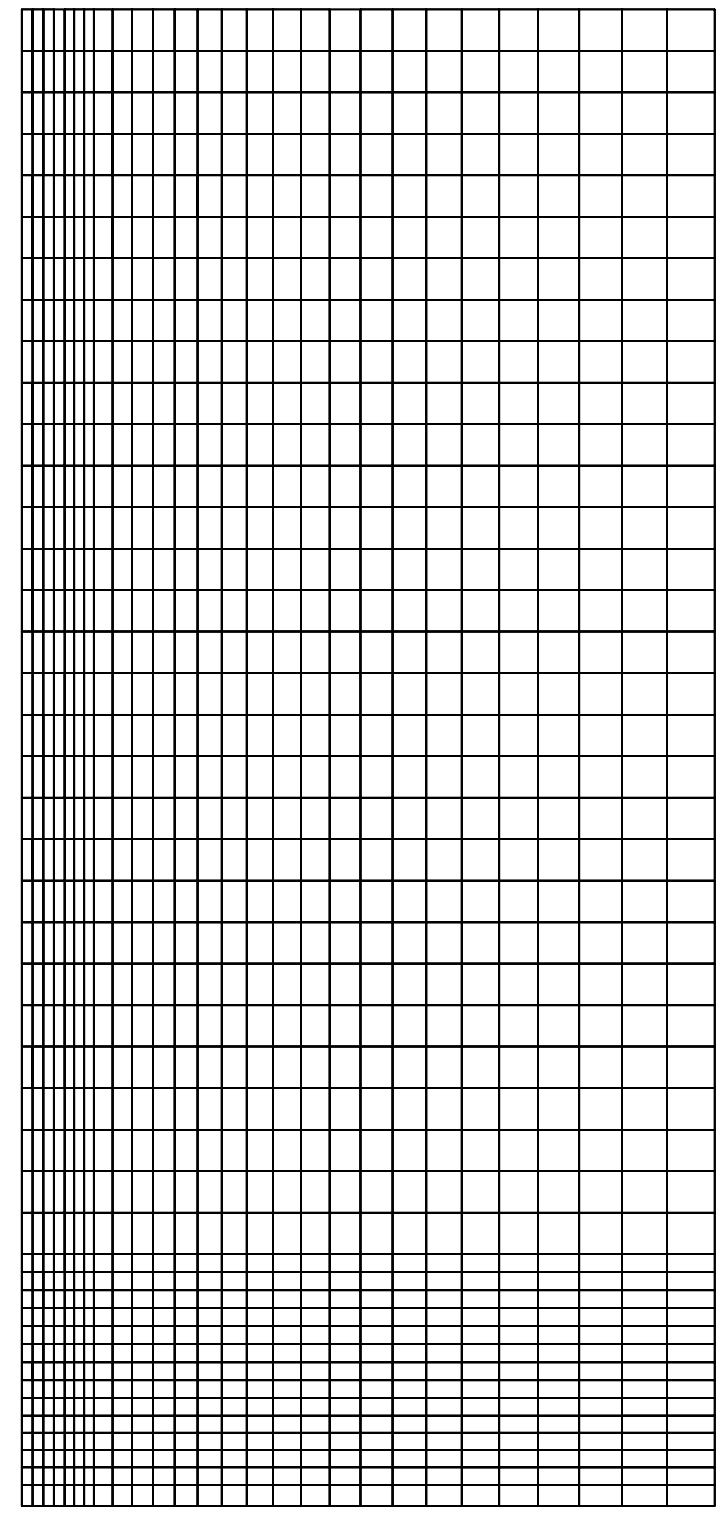

Figure 20. Grid slice parallel to the attic centerline, perpendicular to the wood attic joist, from the three-dimensional model of the standard insulation attic space.

home is divided by this volumetric flow rate and the resulting air change per hour is divided by 20 (ACH50/20) for a good estimate of average air infiltration rate ${ }^{6}$. Tables 12 and 13 give results from the blower door tests. A correlation coefficient is used to measure the goodness of fit of the equation with all data points in Tables 12 and 13 . These results show that the two units had air infiltration rates that differed by only about 
3.6\%. Blower door results yielded 1.08 air changes per hour for the standard unit and 1.12 air changes per hour for the upgraded unit. These units had essentially the same air tightness.

Table 12. Tests Results from Minneapolis Blower Door Test for Standard Unit (Unit Volume $\left.5000 \mathrm{ft}^{3}\right)$.

\begin{tabular}{|c|c|c|c|}
\hline $\begin{array}{l}\text { Fan Pressure } \\
\text { (Pascals) }\end{array}$ & $\begin{array}{l}\text { Temp Corrected } \\
\text { (Pascals) }\end{array}$ & $\begin{array}{l}\text { Flow Rate } \\
\left(\mathrm{ft}^{3} / \mathrm{min}\right)\end{array}$ & $\begin{array}{l}\text { Envelope } \Delta \mathrm{P} \\
\quad(\text { Pascals })\end{array}$ \\
\hline 56.0 & 55.05 & 3558.06 & 172.1 \\
\hline 52.1 & 50.95 & 3424.23 & 152.0 \\
\hline 45.2 & 44.20 & 3191.92 & 137.0 \\
\hline 40.2 & 39.31 & 3012.13 & 121.5 \\
\hline 35.3 & 34.52 & 2824.63 & 104.8 \\
\hline 28.8 & 28.16 & 2554.21 & 91.4 \\
\hline 24.2 & 23.66 & 2343.60 & 81.7 \\
\hline 20.5 & 20.04 & 2158.98 & 73.4 \\
\hline 14.1 & 13.78 & 1794.22 & 50.4 \\
\hline 10.5 & 10.26 & 1550.83 & 38.2 \\
\hline \multicolumn{2}{|c|}{$\begin{array}{l}\frac{\text { Logarithmic Fit }}{\log V=0.57335} * \log \Delta \mathrm{P}+2.27906 \\
\text { Correlation Coefficient }=0.997\end{array}$} & \multirow{2}{*}{\multicolumn{2}{|c|}{$\begin{array}{l}\text { CFM @ } 50 \text { Pascals = } 1791.28 \\
\text { Effective Leakage Area }=\mathbf{1 2 0 . 4} \text { in }^{\mathbf{2}}\end{array}$}} \\
\hline \multicolumn{2}{|c|}{$\begin{array}{l}\text { Power Fit } \\
\mathrm{V}=190.144 * \Delta \mathrm{P}^{0.57335} \\
\text { Correlation Coefficient }=0.997\end{array}$} & & \\
\hline
\end{tabular}

Calculations were made for each month to determine the quantity of energy loss/gain due to air infiltration. These calculations were made using Eq. (18) where $\mathrm{Q}_{\text {air }}$ is

$$
Q_{\text {air }}=\dot{m} C_{p} \Delta T
$$

the energy required to heat or cool the infiltrating air into the manufactured home per hour, $\mathrm{C}_{\mathrm{p}}$ is the heat capacity of the air, $\dot{\mathrm{m}}$ is the mass flow rate of air, and $\Delta \mathrm{T}$ is the 
temperature difference between the indoor and entering outdoor air. The mass flow rate of air was calculated by the product of the air density at the indoor temperature, the volume of the manufactured home and the air change per hour rate. The heat capacity for air was taken to be constant at $0.24 \mathrm{Btu} / \mathrm{lb} \bullet{ }^{\circ} \mathrm{F}\left(1.005 \mathrm{~kJ} / \mathrm{kg} \bullet{ }^{\circ} \mathrm{C}\right)$. The change in temperature is calculated by subtracting the average monthly air temperature from an indoor temperature of $68^{\circ} \mathrm{F}\left(20^{\circ} \mathrm{C}\right)$ for the winter months. For the summer months, the

Table 13. Tests Results from Minneapolis Blower Door Test for Upgraded Unit (Unit Volume $\left.4900 \mathrm{ft}^{3}\right)$.

\begin{tabular}{|c|c|c|c|}
\hline $\begin{array}{l}\text { Fan Pressure } \\
\text { (Pascals) }\end{array}$ & $\begin{array}{l}\text { Temp Corrected } \\
\text { (Pascals) }\end{array}$ & $\begin{array}{c}\text { Flow Rate } \\
\left(\mathrm{ft}^{3} / \mathrm{min}\right)\end{array}$ & $\begin{array}{c}\text { Envelope } \Delta \mathrm{P} \\
\text { (Pascals) }\end{array}$ \\
\hline 57.5 & 56.23 & 3595.36 & 169.0 \\
\hline 52.3 & 51.14 & 3430.72 & 159.9 \\
\hline 49.9 & 48.80 & 3351.95 & 149.1 \\
\hline 44.9 & 43.91 & 3181.43 & 140.0 \\
\hline 41.2 & 40.29 & 3048.97 & 124.2 \\
\hline 36.0 & 35.20 & 2852.19 & 114.2 \\
\hline 32.4 & 31.68 & 2707.39 & 100.4 \\
\hline 26.5 & 25.91 & 2451.21 & 83.0 \\
\hline 21.7 & 21.22 & 2220.58 & 65.9 \\
\hline 15.0 & 14.67 & 1849.96 & 50.3 \\
\hline 9.9 & 9.68 & 1506.36 & 34.3 \\
\hline \multicolumn{2}{|c|}{$\begin{array}{l}\text { Logarithmic Fit } \\
\text { Log } \mathrm{V}=0.53586 * \log \Delta \mathrm{P}+2.35911 \\
\text { Correlation Coefficient }=0.9987\end{array}$} & \multirow{2}{*}{\multicolumn{2}{|c|}{$\begin{array}{l}\text { CFM @ } 50 \text { Pascals }=1860.031 \\
\text { Effective Leakage Area }=\mathbf{1 3 7 . 8} \mathbf{~ i n}^{\mathbf{2}} \\
\begin{array}{l}\text { ACH50 }=22.41 \\
\text { ACH50/20 }=\mathbf{1 . 1 2}\end{array}\end{array}$}} \\
\hline \multicolumn{2}{|c|}{$\begin{array}{l}\text { Power Fit } \\
\mathrm{V}=229.78 * \Delta \mathrm{P}^{0.53586} \\
\text { Correlation Coefficien }\end{array}$} & & \\
\hline
\end{tabular}

indoor temperature of $74^{\circ} \mathrm{F}\left(23^{\circ} \mathrm{C}\right)$ is subtracted from the average monthly air temperature. These calculations account for the sensible energy required to condition the infiltration air. The latent energy required to condition the air due to differences between 
the indoor and outdoor humidity was not calculated.

In the winter months, large temperature differences exist between the indoor and average outdoor air temperatures. These large temperature differences caused the winter $\mathrm{Q}_{\text {air }}$ calculated using Eq. (18) to be much larger than the $\mathrm{Q}_{\text {air }}$ for summer conditions. The sensible energy loss due to air infiltration is more significant in the winter than in the summer. The latent load posed by humid summer conditions was not estimated.

The results in Figure 21 show a greater percentage energy loss for the upgraded unit than for the standard unit. Since energy consumption of the upgraded unit is less than the standard unit for each month, the percentage of total air infiltration energy loss is greater for the upgraded unit. Table 14 shows the comparison of monthly heat pump energy use and air infiltration energy loss/gain for the standard and upgraded manufactured home units. Annual calculations (excluding July) show $32.1 \%$ of the energy use by the heat pump for the standard unit is due to air infiltration. The upgraded unit results show $41.0 \%$ of the energy use by the heat pump is due to air infiltration.

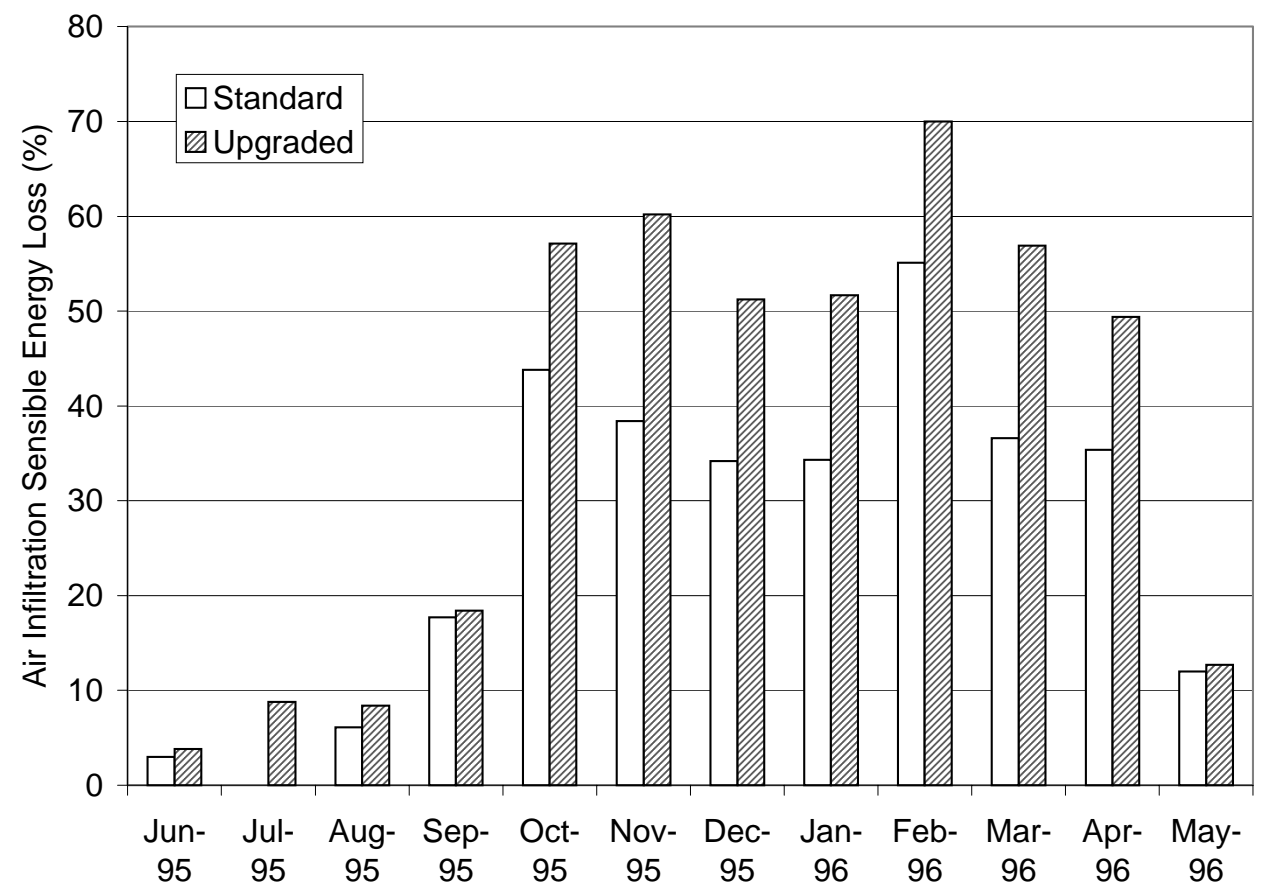

Figure 21. Monthly percentage of air infiltration energy loss for standard and upgraded manufactured home units. 
Table 14. Comparison of Monthly Heat Pump Energy Use and Air Infiltration Energy Loss/Gain for Standard and Upgraded Manufactured Homes - 1995-1996 Data

\begin{tabular}{|l|c|c|c|c|c|c|}
\hline \multirow{2}{*}{ Month } & \multicolumn{3}{|c|}{ Standard Unit $(\mathrm{R}-14)$} & \multicolumn{3}{c|}{ Upgraded Unit (R-28) } \\
\cline { 2 - 8 } & $\begin{array}{c}\mathrm{E}_{\text {total }} \\
(\mathrm{kWh})\end{array}$ & $\begin{array}{c}\mathrm{E}_{\text {air }} \\
(\mathrm{kWh})\end{array}$ & $\mathrm{E}_{\text {air }} / \mathrm{E}_{\text {total }}$ & $\begin{array}{c}\mathrm{E}_{\text {total }} \\
(\mathrm{kWh})\end{array}$ & $\begin{array}{c}\mathrm{E}_{\text {air }} \\
(\mathrm{kWh})\end{array}$ & $\mathrm{E}_{\text {air }} / \mathrm{E}_{\text {total }}$ \\
\hline June & 418 & 13 & 0.03 & 332 & 13 & 0.04 \\
\hline July & & & & 258 & 23 & 0.09 \\
\hline August & 617 & 38 & 0.06 & 565 & 48 & 0.08 \\
\hline September & 240 & 43 & 0.18 & 227 & 42 & 0.18 \\
\hline October & 215 & 94 & 0.44 & 165 & 94 & 0.57 \\
\hline November & 547 & 210 & 0.38 & 342 & 206 & 0.60 \\
\hline December & 798 & 273 & 0.34 & 522 & 267 & 0.51 \\
\hline January & 873 & 299 & 0.34 & 567 & 293 & 0.52 \\
\hline February & 1070 & 590 & 0.55 & 826 & 578 & 0.70 \\
\hline March & 567 & 208 & 0.37 & 358 & 204 & 0.57 \\
\hline April & 256 & 91 & 0.35 & 180 & 89 & 0.49 \\
\hline May & 280 & 34 & 0.12 & 258 & 33 & 0.13 \\
\hline Total & $\mathbf{5 8 8 1}$ & $\mathbf{1 8 9 1}$ & $\mathbf{0 . 3 2}$ & $\mathbf{4 6 0 0}$ & $\mathbf{1 8 8 8}$ & $\mathbf{0 . 4 1}$ \\
\hline
\end{tabular}

\subsubsection{Total Energy Use for Heating and Cooling}

Table 15 contains the cumulative power use for the two full-size manufactured home units. The electric power used for the heat pump and air circulation was submetered and reported under the "Heat Pump". The heading "Resistance" refers to power consumed by the resistive heating section in the heat pump. These cumulative power readings have a zero time effect of $86 \mathrm{kWh}$ since the watt-hour meters were not zeroed. This difference loses significance as the number of months of operation increases. The power bill for maintaining the two units with the same interior conditions is proportional to the number under "Total". It is clear that the upgraded unit is using less 
electrical power than the standard unit. The difference, however, is not due totally to the upgraded insulation package. Slight differences in air exchange rates, for example, were measured, and the exact response of the control equipment was not determined. Since these units represent two units built at the same time a direct comparison of monthly power usages has some value.

Table 16 contains monthly electric power use for heating and cooling for the two units and the ratio of standard unit use divided by upgraded unit use. The value for the ratio fluctuates about 1.30 , the overall value for the ratio for 40 months of operation.

The two manufactured home units were heated with only resistive heating during February 1996. The ratio of standard/upgraded power use for this month is 1.27 , a ratio that is very close to the overall ratio. The absolute power use for February 1996 is substantially greater than the earlier or later months. This can readily be seen in Table 16.

The power use ratio of 1.30 is too large to be explained by the difference in roof cavity insulation. The upgraded unit, however, did show better thermal performance than the standard. Some of the difference is no doubt manufacturing variability. 
Table 15. Electric Power Use (kWh) in the Manufactured Home Units

\begin{tabular}{|c|c|c|c|c|c|c|}
\hline \multirow[b]{2}{*}{ Date } & \multicolumn{3}{|c|}{ Upgraded Unit (R-28) } & \multicolumn{3}{|c|}{ Standard Unit (R-14) } \\
\hline & Heat Pump & Resistance & Total & Heat Pump & Resistance & Total \\
\hline $01 / 95$ & 0657 & 0112 & 769 & 0608 & 0075 & 683 \\
\hline $02 / 95$ & 1218 & 0225 & 1443 & 1173 & 0182 & 1355 \\
\hline $03 / 95$ & 1711 & 0333 & 2044 & 1772 & 0245 & 2017 \\
\hline $04 / 95$ & 1938 & 0367 & 2305 & 2068 & 0271 & 2339 \\
\hline $05 / 95$ & 2083 & 0374 & 2457 & 2224 & 0276 & 2500 \\
\hline $06 / 95$ & 2328 & 0375 & 2703 & 2484 & 0276 & 2760 \\
\hline $07 / 95$ & 2583 & 0375 & 2958 & 2813 & 0276 & 3089 \\
\hline $08 / 95$ & 3176 & 0375 & 3551 & 2847 & 0276 & 3123 \\
\hline $09 / 95$ & 3723 & 0375 & 4098 & 3367 & 0276 & 3643 \\
\hline $10 / 95$ & 3981 & 0375 & 4356 & 3603 & 0276 & 3879 \\
\hline $11 / 95$ & 4148 & 0376 & 4524 & 3751 & 0281 & 4032 \\
\hline $12 / 95$ & 4448 & 0424 & 4872 & 4223 & 0362 & 4585 \\
\hline \multicolumn{7}{|c|}{ 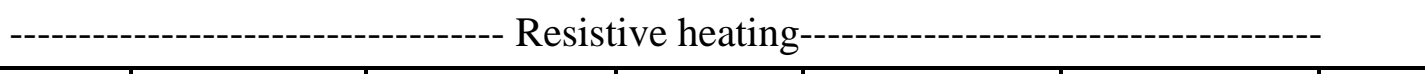 } \\
\hline $01 / 96$ & 4896 & 0498 & 5394 & 4913 & 0468 & 5381 \\
\hline $02 / 96$ & 5367 & 0625 & 5992 & 5642 & 0645 & 6287 \\
\hline $03 / 96$ & 5404 & 1376 & 6780 & 5668 & 1623 & 7291 \\
\hline $04 / 96$ & 5713 & 1426 & 7139 & 6182 & 1696 & 7828 \\
\hline \multicolumn{7}{|c|}{ - } \\
\hline $05 / 96$ & 5884 & 1439 & 7323 & 6418 & 1722 & 8140 \\
\hline $06 / 96$ & 6143 & 1440 & 7583 & 6702 & 1722 & 8424 \\
\hline $07 / 96$ & 6492 & 1440 & 7932 & 7127 & 1722 & 8849 \\
\hline $08 / 96$ & 6866 & 1440 & 8306 & 7583 & 1722 & 9305 \\
\hline \multicolumn{7}{|c|}{ 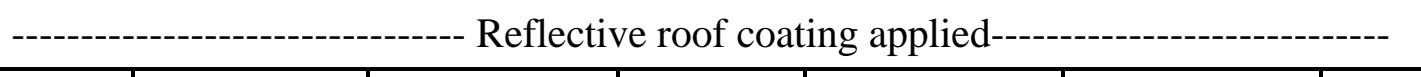 } \\
\hline $09 / 96$ & 7241 & 1440 & 8681 & 7973 & 1722 & 9695 \\
\hline $10 / 96$ & 7386 & 1440 & 8826 & 8108 & 1722 & 9830 \\
\hline
\end{tabular}




\begin{tabular}{|c|c|c|c|c|c|c|}
\hline \multirow[b]{2}{*}{ Date } & \multicolumn{3}{|c|}{ Upgraded Unit (R-28) } & \multicolumn{3}{|c|}{ Standard Unit (R-14) } \\
\hline & Heat Pump & Resistance & Total & Heat Pump & Resistance & Total \\
\hline $11 / 96$ & 7524 & 1442 & 8966 & 8253 & 1725 & 9978 \\
\hline $12 / 96$ & 7861 & 1483 & 9344 & 8806 & 1795 & 10601 \\
\hline $01 / 97$ & 8248 & 1532 & 9780 & 9418 & 1874 & 11292 \\
\hline $02 / 97$ & 8825 & 1606 & 10431 & 10166 & 2057 & 12223 \\
\hline 03/97 & 9233 & 1663 & 10896 & 10732 & 2137 & 12869 \\
\hline $04 / 97$ & 9443 & 1677 & 11120 & 11082 & 2161 & 13243 \\
\hline $06 / 97$ & 9698 & 1686 & 11384 & 11493 & 2173 & 13666 \\
\hline $07 / 97$ & 9758 & 1686 & 11444 & 11547 & 2173 & 13720 \\
\hline 08/97 & 10003 & 1686 & 11689 & 11857 & 2173 & 14030 \\
\hline 09/97 & 10236 & 1686 & 11922 & 12043 & 2173 & 14216 \\
\hline $11 / 97$ & 10603 & 1692 & 12295 & 12402 & 2183 & 14585 \\
\hline $12 / 97$ & 11007 & 1723 & 12730 & 13008 & 2250 & 15258 \\
\hline $01 / 98$ & 11442 & 1797 & 13239 & 13723 & 2357 & 16080 \\
\hline 02/98 & 11891 & 1876 & 13767 & 14476 & 2472 & 16948 \\
\hline 03/98 & 12232 & 1938 & 14170 & 14994 & 2553 & 17547 \\
\hline 04/98 & 12516 & 1977 & 14493 & 15562 & 2623 & 18185 \\
\hline $06 / 98$ & 12797 & 1982 & 14779 & 15954 & 2633 & 18587 \\
\hline $07 / 98$ & 13235 & 1982 & 15217 & 16206 & 2633 & 18839 \\
\hline 08/98 & 13413 & 1982 & 15395 & 16356 & 2633 & 18989 \\
\hline 09/98 & 13633 & 1982 & 15615 & 16574 & 2633 & 19207 \\
\hline $10 / 98$ & 13895 & 1982 & 15877 & 16809 & 2633 & 19442 \\
\hline $11 / 98$ & 13943 & 1983 & 15926 & 16987 & 2634 & 19621 \\
\hline $12 / 98$ & 14156 & 1983 & 16139 & 17335 & 2657 & 19992 \\
\hline $01 / 99$ & 14423 & 2042 & 16465 & 18212 & 2784 & 20996 \\
\hline 02/99 & 14996 & 2117 & 17113 & 18630 & 2835 & 21465 \\
\hline
\end{tabular}


Table 16. Monthly Power Use for Two Unoccupied Full-Size Single-Wide Manufactured Homes

\begin{tabular}{|l|c|c|c|}
\hline Month & $\begin{array}{c}\text { Upgraded } \\
\text { Unit } \\
(\mathrm{kWh})\end{array}$ & $\begin{array}{c}\text { Standard } \\
\text { Unit } \\
(\mathrm{kWh})\end{array}$ & $\begin{array}{c}\text { Standard/ } \\
\text { Upgraded }\end{array}$ \\
\hline $01 / 95$ & 674 & 672 & 1.00 \\
\hline $02 / 95$ & 601 & 662 & 1.10 \\
\hline $03 / 95$ & 261 & 322 & 1.23 \\
\hline $04 / 95$ & 152 & 161 & 1.06 \\
\hline $05 / 95$ & 246 & 260 & 1.06 \\
\hline $06 / 95$ & 255 & 329 & 1.29 \\
\hline $08 / 95$ & 547 & 520 & 0.95 \\
\hline $09 / 95$ & 258 & 236 & 0.91 \\
\hline $10 / 95$ & 168 & 153 & 0.91 \\
\hline $11 / 95$ & 348 & 553 & 1.59 \\
\hline $12 / 95$ & 522 & 796 & 1.52 \\
\hline $01 / 96$ & 598 & 906 & 1.52 \\
\hline $02 / 96$ & 788 & 1004 & 1.27 \\
\hline (a) & & 639 & 1.39 \\
\hline $03 / 96$ & 359 & 587 & 1.63 \\
\hline $04 / 96$ & 184 & 262 & 1.42 \\
\hline $05 / 96$ & 260 & 284 & 1.09 \\
\hline $06 / 96$ & 349 & 425 & 1.22 \\
\hline $07 / 96$ & 374 & 456 & 1.22 \\
\hline $08 / 96$ & 375 & 390 & 1.04 \\
\hline $09 / 96$ & 145 & 135 & 0.93 \\
\hline $10 / 96$ & 107 & 148 & 1.38 \\
\hline $11 / 96$ & 378 & 623 & 1.67 \\
\hline $12 / 96$ & 436 & 691 & 1.58 \\
\hline $01 / 97$ & 651 & 931 & 646 \\
\hline $02 / 97$ & 465 & & \\
\hline
\end{tabular}

\begin{tabular}{|c|c|c|c|}
\hline Month & $\begin{array}{c}\text { Upgraded } \\
\text { Unit } \\
(\mathrm{kWh})\end{array}$ & $\begin{array}{l}\text { Standard } \\
\text { Unit } \\
(\mathrm{kWh})\end{array}$ & $\begin{array}{l}\text { Standard/ } \\
\text { Upgraded }\end{array}$ \\
\hline $03 / 97$ & 224 & 374 & 1.67 \\
\hline $07 / 97$ & 245 & 310 & 1.27 \\
\hline $\begin{array}{l}08 / 97 \\
\text { (b) }\end{array}$ & 233 & 186 & 0.80 \\
\hline $11 / 97$ & 435 & 673 & 1.55 \\
\hline $12 / 97$ & 509 & 822 & 1.61 \\
\hline $01 / 98$ & 528 & 868 & 1.64 \\
\hline $02 / 98$ & 403 & 599 & 1.49 \\
\hline 03/98 & 323 & 638 & 1.98 \\
\hline $06 / 98$ & 438 & 252 & 0.58 \\
\hline $07 / 98$ & 178 & 150 & 0.84 \\
\hline 08/98 & 220 & 218 & 0.99 \\
\hline $09 / 98$ & 262 & 235 & 0.90 \\
\hline $11 / 98$ & 213 & 371 & 1.74 \\
\hline $12 / 98$ & 326 & 469 & 1.44 \\
\hline $01 / 99$ & 648 & 1001 & 1.55 \\
\hline Total & 14868 & 19321 & 1.30 \\
\hline
\end{tabular}

(a) Units were conditioned with resistive heat only.

(b) Radiation Control coating applied. 


\subsubsection{Effect of Radiation Control Coating Applied to Roof}

The exterior surfaces of the roofs of both single-wide manufactured homes were painted with radiation control coating on August 9, 1996. The radiation control coating was manufactured by Solex ${ }^{\mathrm{TM}}$, a coating with a solar reflectance of 0.86 and an infrared emittance of approximately 0.9 . The coating was applied in accordance with manufacturer's instructions. A clear protective coating was applied after the relatively thick white coating had cured. The radiation control coating reflects a large fraction of the incoming solar flux thus reducing the roof surface temperature and heat gain across the roof assembly. ${ }^{7}$

Data from the manufactured homes were merged with separately recorded local weather data. Although the weather data were not synchronous with the heat flux/temperature data, they were matched within the nearest hour. Two approaches were used in this particular examination of the data. First, a multiple regression analysis was done using summer-time data before and after the roof coatings were applied. This analysis assumed quasi-steady-state conditions and produced estimates for indoor temperature, overall attic assembly U-value, and roof surface emittance. The second approach examined changes due to the application of a roof coating by selecting "similar" summer days from the before and after summer seasons. This approach allowed us to examine the attic temperature variations throughout the day, as well as daily average values.

The Multi variate regression model is based on the sol-air temperature, defined as "the temperature of the outdoor air that, in the absence of all radiation changes, gives the same rate of heat entry into the surface as would the combination of incident solar radiation, radiant energy exchange with the sky and other outdoor surroundings, and convective heat exchange with the outdoor air" as shown in Eqs. 20, 21, and 22.

$$
\frac{q}{A}=\alpha I_{t}+h_{o}\left(T_{o}-T_{s}\right)-\varepsilon \Delta R
$$




$$
\frac{q}{A}=h_{o}\left(T_{e}-T_{s}\right)
$$

$$
T_{e}=T_{o}+\frac{\alpha I_{t}}{h_{o}}-\frac{\varepsilon \Delta R}{h_{o}}
$$

Where:

$$
\begin{aligned}
& \mathrm{q} / \mathrm{A}=\text { heat flux into the surface } \\
& \alpha=\text { absorptance of surface for solar radiation } \\
& \mathrm{I}_{\mathrm{t}}=\text { total solar radiation incident on surface, } \mathrm{Btu} / \mathrm{h}-\mathrm{ft}^{2} \\
& \mathrm{~h}_{\mathrm{o}}=\text { coefficient of heat transfer by long-wave radiation and convection } \\
& \text { at outer surface, Btu/h- } \mathrm{ft}^{2}-{ }^{\circ} \mathrm{F} \\
& \mathrm{T}_{\mathrm{o}}=\text { outdoor air temperature, }{ }^{\circ} \mathrm{F} \\
& \mathrm{T}_{\mathrm{s}}=\text { surface temperature, }{ }^{\circ} \mathrm{F} \\
& \varepsilon=\text { hemispherical emittance of surface } \\
& \Delta \mathrm{R}=\text { difference between long-wave radiation incident on surface from } \\
& \text { sky and surroundings and radiation emitted by black body at } \\
& \text { outdoor air temperature, Btu/h- } \mathrm{ft}^{2} \text {, and } \\
& \mathrm{T}_{\mathrm{e}} \quad=\quad \text { sol-air temperature, }{ }^{\circ} \mathrm{F} \text {. }
\end{aligned}
$$

ASHRAE gives typical values of $\Delta \mathrm{R}$ and $\mathrm{h}_{\mathrm{o}}$ for horizontal surfaces that receive long-wave radiation from the sky only. ${ }^{2}$ Given the shallow slope of the manufactured home roofs and their elevation above the ground, these were considered applicable. For the units given above, $\Delta \mathrm{R}$ is about $20 \mathrm{Btu} / \mathrm{h}-\mathrm{ft}^{2}$ and $h_{\mathrm{o}}$ is about $3 \mathrm{Btu} / \mathrm{h}-\mathrm{ft}^{2}-{ }^{\circ} \mathrm{F}$. A reasonable value for the long-wave hemispherical emittance, $\varepsilon$, is 0.9 . Considering the roof and attic as an assembly, and defining the overall thermal conductance, $\mathrm{U}$, of that assembly, produces Eq. 23. These equations can be rearranged to give Eq. 24.

$$
\frac{q}{A}=U\left(T_{e}-T_{i}\right)
$$




$$
\frac{q}{A}=-U\left(T_{i n}+\frac{\varepsilon \Delta R}{h_{o}}\right)+U T_{o}+\frac{U \alpha}{h_{o}} I_{t}
$$

where $T_{\text {in }}$ is the indoor temperature, and $U$ is the overall conductance of the roof/attic assembly.

When Eq. 24 is used with the measured values of heat flux, outdoor air temperature, incident solar radiation, and the assumed values for $\Delta \mathrm{R}, \varepsilon$, and $\mathrm{h}_{\mathrm{o}}$, multivariate regression produces the values for indoor temperature, overall conductance, and emissivity shown in Table 17. The regression results show that the overall thermal resistance has been significantly increased and that the solar absorptivity, $\alpha$, of the roof has been reduced by approximately 50\%. The relatively low regression coefficients show that this simple model is not adequate to explain all the complex interactions between the environment and the attic assembly. These efforts also revealed that the indoor temperature was somewhat hotter during the second summer, a finding that was confirmed by examination of the recorded gypsum temperatures. The cause of this temperature rise is unknown, given that the thermostat controls were unchanged.

Table 17. Multi Variate Regression Results for Eq. 24 for Data Taken During Daytime Hours of June, July, and August of 1996 and 1997.

\begin{tabular}{|c|c|c|c|c|c|c|c|c|}
\hline \multicolumn{9}{|c|}{ Regression model: $(\mathrm{q} / \mathrm{A})_{\mathrm{avg}}=\mathrm{C}_{1}+\mathrm{C}_{2} \mathrm{~T}_{\mathrm{o}}+\mathrm{C}_{3} \mathrm{I}_{\mathrm{t}}$} \\
\hline House & $\begin{array}{l}\text { Roof } \\
\text { Coating }\end{array}$ & $\mathrm{R}^{2}$ & $\begin{array}{l}\mathrm{C}_{1} \\
(\mathrm{SD})\end{array}$ & $\begin{array}{l}\mathbf{T}_{\text {in }} \\
\left({ }^{\circ} \mathbf{F}\right)\end{array}$ & $\begin{array}{l}\mathrm{C}_{2} \\
(\mathrm{SD})\end{array}$ & $\begin{array}{l}R=1 / U \\
\left(h-\mathbf{f t}^{2}-{ }^{\circ} \mathbf{F}\right. \\
/ \text { Btu })\end{array}$ & $\begin{array}{l}\mathrm{C}_{3} \\
(\mathrm{SD})\end{array}$ & $\boldsymbol{\alpha}$ \\
\hline \multirow[t]{2}{*}{ Upgraded } & no & .59 & $\begin{array}{l}-3.92 \\
(0.26)\end{array}$ & 70 & $\begin{array}{l}.052 \\
(0.0036)\end{array}$ & 19 & $\begin{array}{l}.0050 \\
(0.00025)\end{array}$ & .29 \\
\hline & yes & .52 & $\begin{array}{l}-2.25 \\
(0.095)\end{array}$ & 74 & $\begin{array}{l}.030 \\
(0.0014)\end{array}$ & 33 & $\begin{array}{l}.000936 \\
(0.00013)\end{array}$ & .10 \\
\hline \multirow[t]{2}{*}{ Standard } & no & .65 & $\begin{array}{l}-3.73 \\
(0.37) \\
\end{array}$ & 74 & $\begin{array}{l}.047 \\
(0.0052)\end{array}$ & 21 & $\begin{array}{l}.0109 \\
(.00037)\end{array}$ & .70 \\
\hline & yes & .78 & $\begin{array}{l}-2.63 \\
(0.083)\end{array}$ & 85 & $\begin{array}{l}.029 \\
(0.0012)\end{array}$ & 34 & $\begin{array}{l}.0290 \\
(0.0012)\end{array}$ & .35 \\
\hline
\end{tabular}


The second analysis approach was to examine the weather data from the 1996 and 1997 summer periods. These data were examined by comparing the maximum and average values of both the air temperature and the incident solar radiation. Six pairs of days were selected and the hourly profiles for the air temperature and solar radiation were examined. The best two pairs of days were then selected, sets 2 and 4 . The weather variables for these two pairs of days are shown in Table 18 and Figs. 22 and 23.

Examining data from these two pairs of similar days shows that the difference between the attic ridge temperature and the outdoor air temperature was significantly modified by the roof coating (see Figs. 24 and 25). This temperature difference, which ranged from noontime highs of 40 to $80^{\circ} \mathrm{F}\left(22\right.$ to $\left.44^{\circ} \mathrm{C}\right)$ was cut down to about $10^{\circ} \mathrm{F}$ $\left(5.6^{\circ} \mathrm{C}\right)$ by the application of the radiation-control coating.

Table 18. Comparison of Weather Variables for Selected Days from the Summers of 1996 and 1997.

\begin{tabular}{|c|c|c|c|c|c|}
\hline Set & Date & $\begin{array}{l}\text { Average air } \\
\text { temperature } \\
\left({ }^{\circ} \mathrm{F}\right)\end{array}$ & $\begin{array}{l}\text { Maximum air } \\
\text { temperature } \\
\left({ }^{\circ} \mathrm{F}\right)\end{array}$ & $\begin{array}{l}\text { Average solar } \\
\text { radiation } \\
\left(\mathrm{Btu} / \mathrm{hr} \cdot \mathrm{ft}^{2}\right)\end{array}$ & $\begin{array}{l}\text { Maximum } \\
\text { solar radiation } \\
\left(\mathrm{Btu} / \mathrm{hr} \cdot \mathrm{ft}^{2}\right) \\
\end{array}$ \\
\hline 2 & Jul 24, 1996 & 76.0 & 85.9 & 95.1 & 295.4 \\
\hline 2 & Jun 19, 1997 & 75.1 & 83.9 & 96.4 & 294.2 \\
\hline 4 & Jul 19, 1996 & 81.5 & 90.6 & 89.4 & 288.8 \\
\hline 4 & Aug 16, 1997 & 82.1 & 90.1 & 86.2 & 286.5 \\
\hline
\end{tabular}

The major thermal benefit of a radiation-control coating is reduced air conditioning load during the summer. Because of variations in the indoor air temperature between the two seasons, the measured attic heat fluxes were not used to quantify this effect. However, the significant decreases in both overall thermal conductance and the solar absorptance shown in Table 17 indicate that summer time heat transfer through the roof should be significantly decreased. An effort was therefore made to estimate these savings for a variety of climates.

Eleven roof-assembly DOE 2.1E simulations were completed using typical meteorological year weather files for nine U.S. cities. The simulations were carried out 


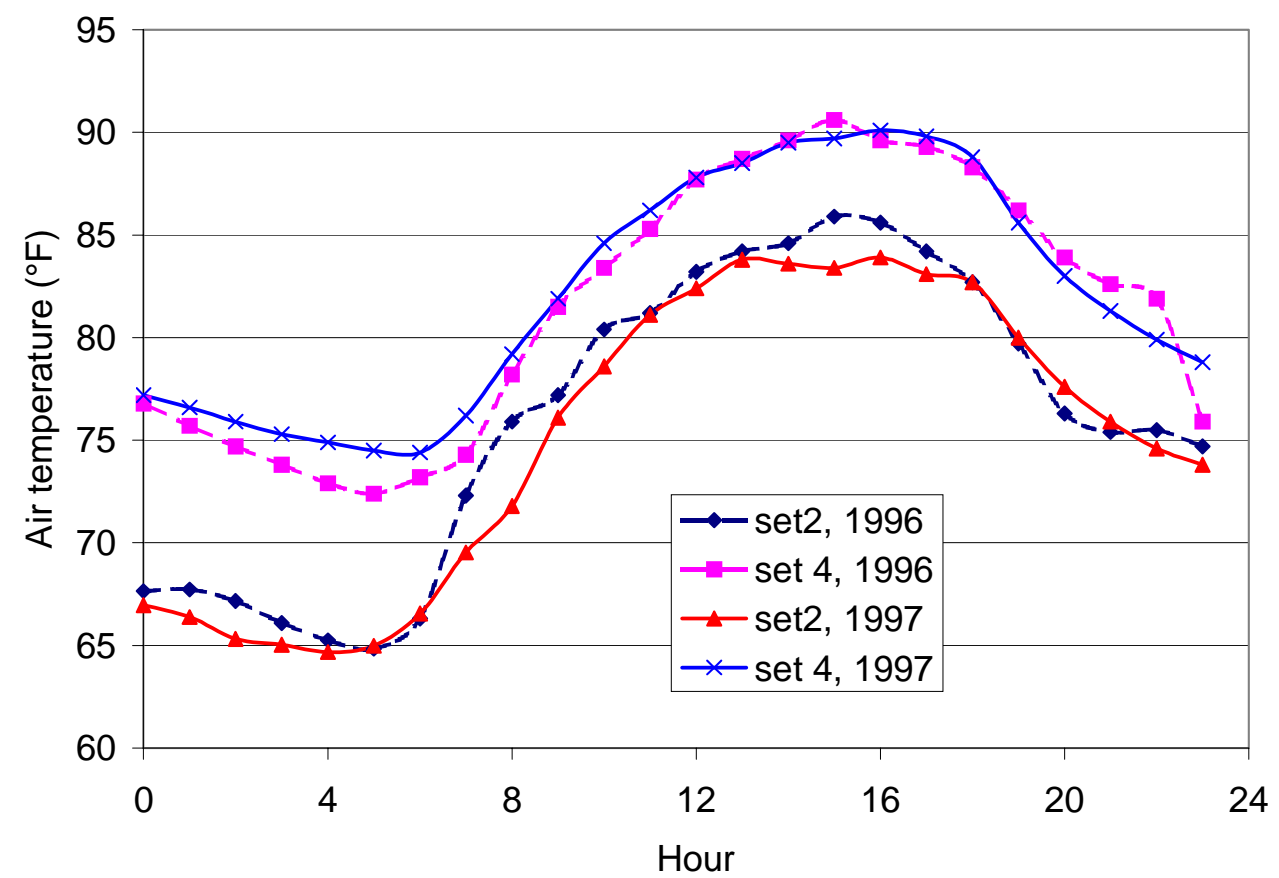

Figure 22. Comparison of outdoor air temperatures for similar summer days.

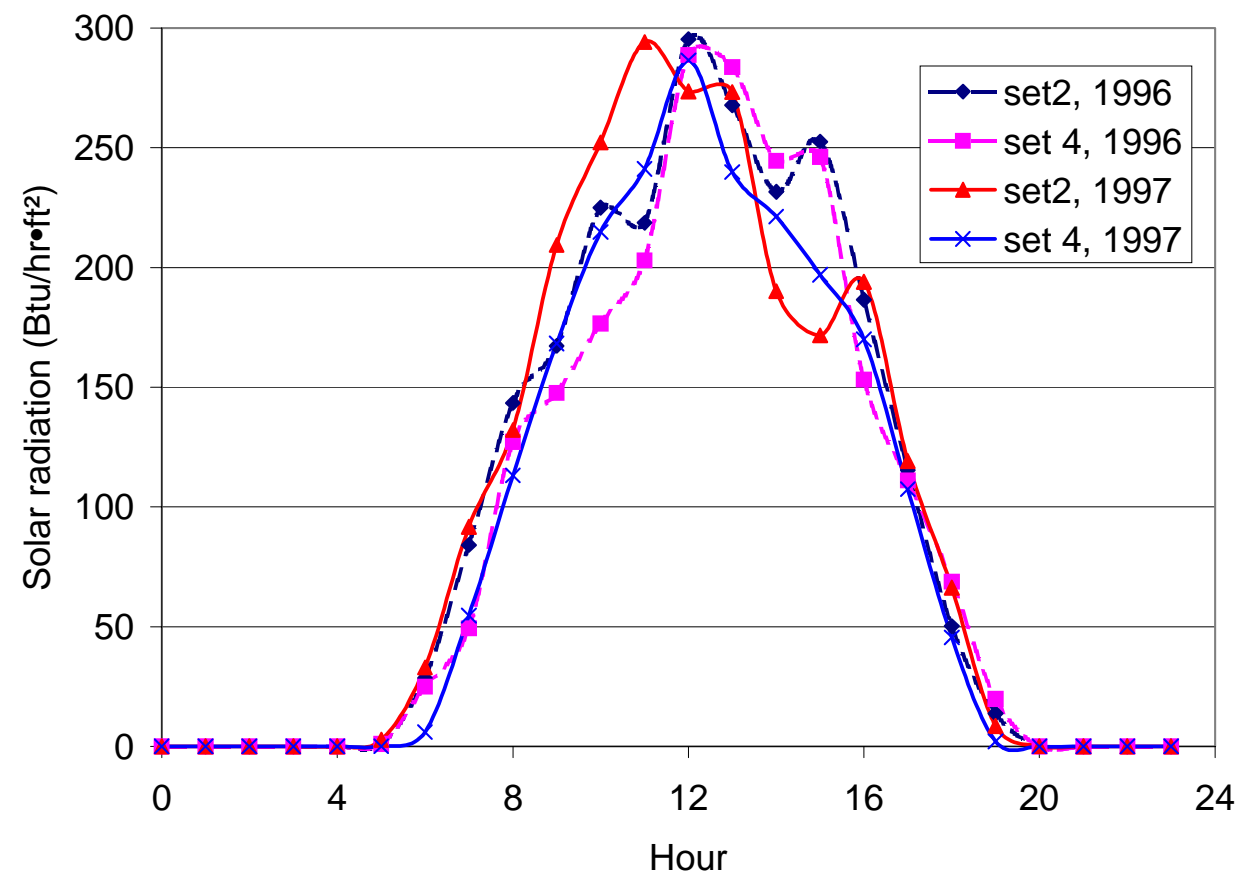

Figure 23. Comparison of incident solar radiation for similar summer days. 


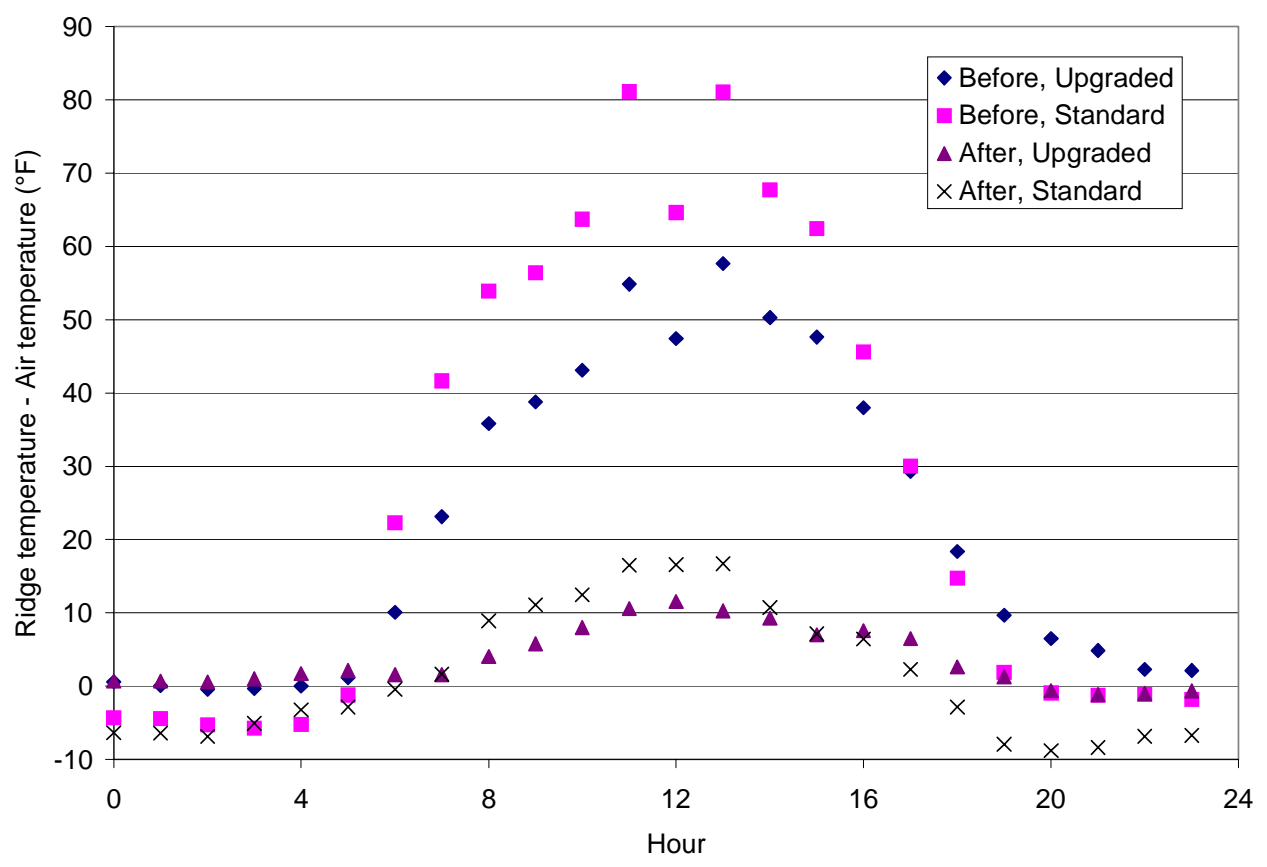

Figure 24. Comparison of temperature differences between the attic ridge and the outdoor air for similar summer days (set 2) before and after application of reflective roof coating.

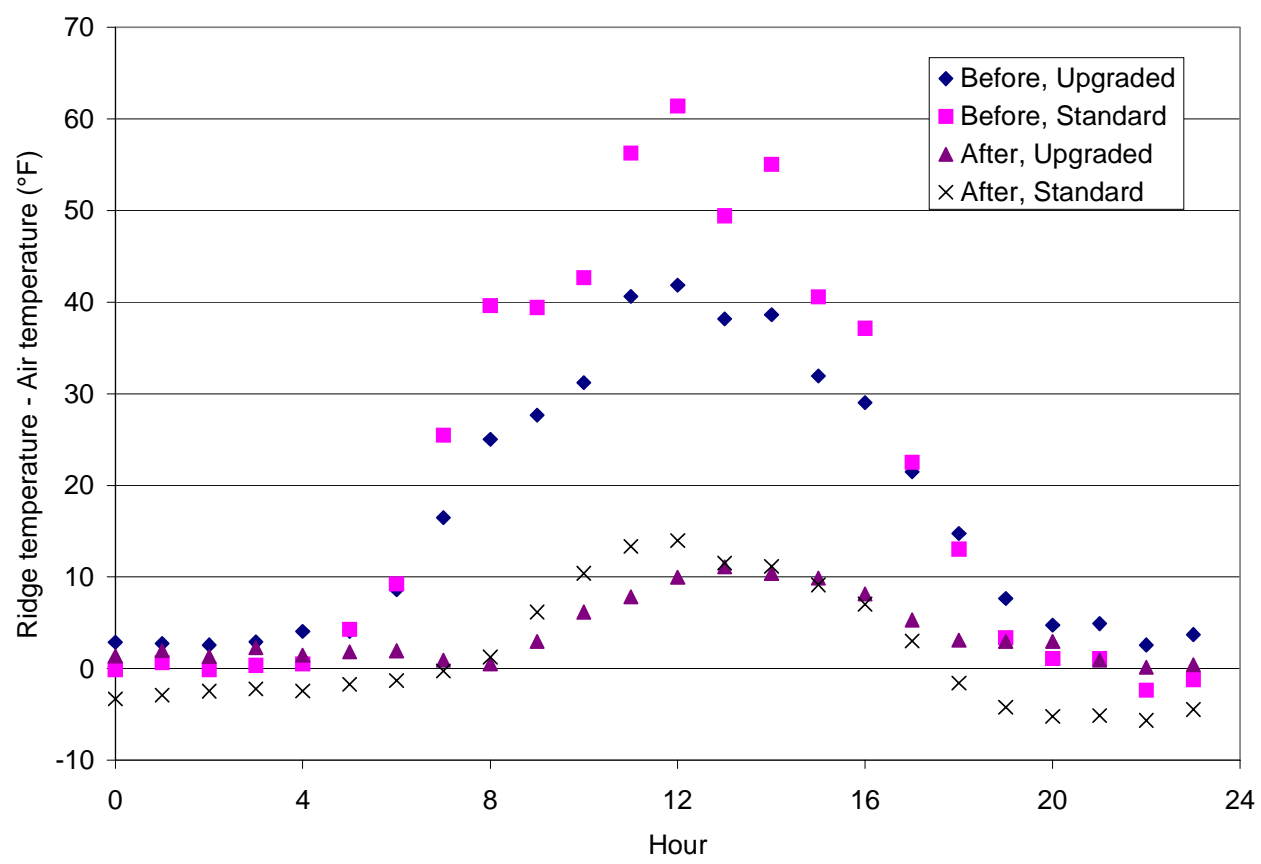

Figure 25. Comparison of temperature differences between the attic ridge and the outdoor air for similar summer days (set 4) before and after application of reflective roof coating. 
for a single-wide manufactured home roof assembly like that studied in the project. The simulation parameters were the slope of the roof, equal to $15.2^{\circ}$, and area of the roof, equal to $345.8 \mathrm{ft}^{2}\left(32.2 \mathrm{~m}^{2}\right)$. The roof assembly was specified to contain fiberglass batts with a specified thermal resistance. The roof assembly was covered with a roof material with specific solar absorptance and infrared emittance. The simulated unit's heating and cooling equipment was set to operate with a coefficient of performance equal to 1.0.

Therefore, energy output into the simulated building will equal the energy input from the heating/cooling device. Each simulation run resulted in an annual energy consumption for both heating and cooling. A complete set of numerical outputs have been assembled by Andrews. ${ }^{8}$ Table 19 contains a complete set of simulation results for Nashville, Tennessee.

Table 19. DOE 2.1E Roof Coating Simulations for Computational Model Tests Run with Weather Data from Nashville, Tennessee

\begin{tabular}{|c|c|c|c|c|c|}
\hline \multirow{2}{*}{$\begin{array}{c}\text { Roof Cavity } \\
\text { Insulation } \\
\text { R-Value }\end{array}$} & \multirow[t]{2}{*}{ Reflectance } & \multirow[t]{2}{*}{ Emmitance } & \multicolumn{3}{|c|}{ Electrical Power Use $(\mathrm{kWh} / \mathrm{Yr})$} \\
\hline & & & Total & Cooling & Heating \\
\hline 14 & 0.90 & 0.8 & 1928 & 1285 & 643 \\
\hline 14 & 0.85 & 0.8 & 2043 & 1421 & 622 \\
\hline 14 & 0.70 & 0.8 & 2305 & 1733 & 572 \\
\hline 14 & 0.10 & 0.8 & 3170 & 2710 & 460 \\
\hline 14 & 0.05 & 0.8 & 3219 & 2768 & 451 \\
\hline 10 & 0.85 & 0.8 & 2313 & 1502 & 811 \\
\hline 20 & 0.85 & 0.8 & 1775 & 1314 & 461 \\
\hline 30 & 0.85 & 0.8 & 1485 & 1168 & 317 \\
\hline 50 & 0.85 & 0.8 & 1156 & 975 & 181 \\
\hline 30 & 0.85 & 0.5 & 1622 & 1334 & 288 \\
\hline 30 & 0.85 & 0.1 & 1928 & 1698 & 230 \\
\hline
\end{tabular}


An estimate of the savings resulting from the application of a radiation control coating to an absorbing roof can be obtained for a roof cavity insulation of $\mathrm{R}-14\left(\mathrm{R}_{\mathrm{SI}}-2.4\right)$ by subtracting the total electrical use in line 2 of Table 19 from the total electrical use in line 4. $\mathrm{R}-14\left(\mathrm{R}_{\mathrm{SI}^{-}}-2.4\right)$ is the insulation level in the standard unit that was studied in this project. The result is $1127 \mathrm{kWh} / \mathrm{yr}$ or $3.3 \mathrm{kWh} /\left(\mathrm{yr} \bullet \mathrm{ft}^{2}\right.$ of roof) [or $0.31 \mathrm{kWh} /\left(\mathrm{yr}^{\bullet} \mathrm{m}^{2}\right.$ of roof)]. The results in Table 19 show the strong dependence of electrical energy savings on roof cavity insulation R-value. The results also show the modest dependence of electrical use on the surface infrared emittance of the roof.

Table 20 shows the electrical energy use reductions for buildings in nine cities based on the parameters described above. In all of the cities considered there was a reduction in cooling load and an increase in heating load.

Table 20. Annual Electrical Energy Savings for Nine Cities Based on a Roof Cavity Insulation of R-14 ( $\left.\mathrm{R}_{\mathrm{SI}}-2.4\right)$

\begin{tabular}{|l|c|c|c|}
\hline \multirow{2}{*}{ City } & \multicolumn{2}{|c|}{ Electrical Power (kWh/yr) Reduction } \\
\cline { 2 - 4 } & Cooling & Heating & Total \\
\hline Denver & 1571 & -297 & 1274 \\
\hline Los Angeles & 2281 & -162 & 2119 \\
\hline Nashville & 1289 & -162 & 1127 \\
\hline New Orleans & 1508 & -95 & 1413 \\
\hline Miami & 1495 & -17 & 1478 \\
\hline Phoenix & 1858 & -124 & 1734 \\
\hline Rapid City & 1139 & -245 & 894 \\
\hline San Antonio & 1454 & -100 & 1354 \\
\hline Washington, D.C. & 1239 & -197 & 1042 \\
\hline
\end{tabular}




\subsection{Roof Cavity Heat Flow with Vacuum Insulation Panels}

\section{$\underline{\text { 3.4.1 Laboratory Measurements }}$}

Thermal resistance data were obtained for the loose-fill rock wool that was installed in the roof test facility using a heat-flow-meter apparatus built and operated in accordance with ASTM C 518 ${ }^{1}$. The rock wool thermal resistance was measured at mean temperatures 50,75 , and $100^{\circ} \mathrm{F}\left(10,24\right.$, and $\left.39^{\circ} \mathrm{C}\right)$ using the same procedure described for the fiberglass batts. The loose-fill insulation test specimens were $24 \times 24$ in. $(0.61 \times 0.61 \mathrm{~m})$. The laboratory measured apparent thermal conductivities, $\mathrm{k}_{\mathrm{a}}$, for the rock wool insulation are given in Table 21. Equations (25), (26), and (27) provide correlations for $\mathrm{k}_{\mathrm{a}}$ of the rock wool insulation used in this project at 50,75 , and $100^{\circ} \mathrm{F}(10,24$, and $\left.39^{\circ} \mathrm{C}\right)$, respectively.

$$
\begin{array}{ll}
\overline{\mathrm{T}}=50^{\circ} \mathrm{F} & \mathrm{k}_{\mathrm{a}}=0.013935+0.53986 \times 10^{-3} \rho+0.18217 \times 10^{-1} / \rho \\
\overline{\mathrm{T}}=75^{\circ} \mathrm{F} \quad \mathrm{k}_{\mathrm{a}}=0.011753+0.98300 \times 10^{-4} \rho+0.26248 \times 10^{-1} / \rho \\
\overline{\mathrm{T}}=100^{\circ} \mathrm{F} \quad \mathrm{k}_{\mathrm{a}}=0.025641+0.12535 \times 10^{-2} \rho+0.11527 \times 10^{-1} / \rho
\end{array}
$$

where $\mathrm{T}$ is the Temperature, ${ }^{\circ} \mathrm{F}, \mathrm{k}_{\mathrm{a}}$ is the apparent thermal conductivity, Btu/ft$\cdot \mathrm{h} \cdot{ }^{\circ} \mathrm{F}$, and $\rho$ is the density, $\mathrm{lb} / \mathrm{ft}^{3}$.

Measurement of the thermal resistances of the vacuum insulation panels was accomplished with the same apparatus used for the loose-fill rock wool insulations. A relatively large number of panels were measured. Table 22 contains the measured Rvalues at $\overline{\mathrm{T}}=75^{\circ} \mathrm{F}\left(24^{\circ} \mathrm{C}\right)$ for the six panels that were actually installed in the roof test facility. It also shows laboratory results for seven panels that were aged for three years, 
Table 21. Apparent Thermal Conductivity Data for Roof Test Facility Rock Wool as a Function of Temperature and Density (Specimen Dimensions 24x24 In. At Several Thicknesses.)

\begin{tabular}{|c|c|c|c|}
\hline Thickness (ft) & $\overline{\mathrm{T}}\left({ }^{\circ} \mathrm{F}\right)$ & $\mathrm{k}_{\mathrm{a}}\left(\mathrm{Btu} / \mathrm{ft} \bullet \mathrm{h} \bullet{ }^{\circ} \mathrm{F}\right)$ & $\rho\left(\mathrm{lb} / \mathrm{ft}^{3}\right)$ \\
\hline \multirow[t]{3}{*}{0.4922} & 50.0 & 0.02216 & 3.028 \\
\hline & 75.0 & 0.02444 & \\
\hline & 100.0 & 0.02889 & \\
\hline \multirow[t]{3}{*}{0.3500} & 50.0 & 0.02064 & 4.257 \\
\hline & 75.0 & 0.02218 & \\
\hline & 100.0 & 0.02348 & \\
\hline \multirow[t]{3}{*}{0.4659} & 50.0 & 0.02330 & 2.645 \\
\hline & 75.0 & 0.02465 & \\
\hline & 100.0 & (Discarded) & \\
\hline \multirow[t]{3}{*}{0.4035} & 50.0 & 0.02083 & 3.054 \\
\hline & 75.0 & 0.02258 & \\
\hline & 100.0 & 0.02444 & \\
\hline \multirow[t]{3}{*}{0.3451} & 50.0 & 0.02147 & 3.570 \\
\hline & 75.0 & 0.02321 & \\
\hline & 100.0 & 0.02376 & \\
\hline \multirow[t]{3}{*}{0.5414} & 50.0 & 0.0229 & 2.308 \\
\hline & 75.0 & 0.02538 & \\
\hline & 100.0 & 0.02780 & \\
\hline \multirow[t]{3}{*}{0.5249} & 50.0 & 0.02273 & 2.380 \\
\hline & 75.0 & 0.02506 & \\
\hline & 100.0 & 0.02738 & \\
\hline \multirow[t]{3}{*}{0.4921} & 50.0 & 0.02224 & 2.539 \\
\hline & 75.0 & 0.02439 & \\
\hline & 100.0 & 0.02660 & \\
\hline \multirow[t]{3}{*}{0.4101} & 50.0 & 0.02110 & 3.047 \\
\hline & 75.0 & 0.02290 & \\
\hline & 100.0 & 0.02479 & \\
\hline \multirow[t]{3}{*}{0.3416} & 50.0 & 0.02035 & 3.657 \\
\hline & 75.0 & 0.02190 & \\
\hline & 100.0 & 0.02353 & \\
\hline
\end{tabular}


from 1994 to 1997, in an unconditioned warehouse. Some of these panels showed signs of aging as their thermal resistance decreased by 0 to $8 \%$.

Table 22. Vacuum Insulation Panels' Laboratory Measurements of Thermal Conductivity and Resistance at a Mean Temperature of $75^{\circ} \mathrm{f}$ (Note That the R-values Reflect the Actual Measured Panel Thicknesses)

\begin{tabular}{|l|l|l|l|l|l|l|c|}
\hline \multirow{2}{*}{ Panel ID } & \multicolumn{2}{|c|}{$\mathrm{k}_{\mathrm{a}}\left(\mathrm{Btu} \bullet \mathrm{in} / \mathrm{ft}^{2} \bullet \mathrm{h} \bullet{ }^{\circ} \mathrm{F}\right)$} & \multicolumn{2}{c|}{$\mathrm{R}$-Value $\left(\mathrm{ft}^{2} \bullet \mathrm{h} \bullet{ }^{\circ} \mathrm{F} / \mathrm{Btu}\right)$} & \multirow{2}{*}{$\begin{array}{c}\text { Change } \\
(\%)\end{array}$} \\
\cline { 2 - 8 } & $\begin{array}{l}\text { Oct } \\
1994\end{array}$ & $\begin{array}{l}\text { Mar } \\
1997\end{array}$ & $\begin{array}{l}\text { June } \\
1999\end{array}$ & $\begin{array}{l}\text { Oct } \\
1994\end{array}$ & $\begin{array}{l}\text { Mar } \\
1997\end{array}$ & $\begin{array}{c}\text { June } \\
1999\end{array}$ & \\
\hline 11440008 & 0.0509 & 0.0554 & & 15.3 & 14.6 & & -4.4 \\
\hline 11440009 & 0.0529 & 0.0599 & & 14.6 & 13.4 & & -8.2 \\
\hline 11440011 & 0.0527 & 0.0551 & & 14.8 & 14.6 & & -1.3 \\
\hline 11440021 & 0.0552 & 0.0569 & & 14.0 & 14.1 & & 0.2 \\
\hline 11440006 & 0.0547 & 0.0587 & & 14.2 & 13.7 & & -3.6 \\
\hline 1144023 & 0.0535 & 0.0597 & & 14.5 & 13.5 & & -6.9 \\
\hline 18240145 & 0.0535 & 0.0558 & & 14.4 & 14.5 & & 0.4 \\
\hline $18240217 *$ & & 0.0524 & 0.0530 & & 15.1 & 14.9 & -1.1 \\
\hline $18240212^{*}$ & & 0.0518 & 0.1915 & & 15.3 & 4.14 & -73. \\
\hline $18240210^{*}$ & & 0.0525 & 0.0540 & & 15.2 & 14.8 & -2.6 \\
\hline $18240223^{*}$ & & 0.0617 & 0.0624 & & 13.0 & 12.8 & -1.5 \\
\hline $18240218^{*}$ & & 0.0517 & 0.0515 & & 15.4 & 15.5 & 0.6 \\
\hline $18240221^{*}$ & & 0.0518 & 0.1937 & & 15.3 & 4.15 & -73. \\
\hline
\end{tabular}

*used in the Roof Test Facility

\subsubsection{Field Data Analysis}

The vacuum insulation panels listed in Table 22 were installed in the roof test facility in August, 1998. First, the six heat flux transducers were affixed to the plywood separating the conditioned space from the attic space. Then the entire roof cavity of the test facility was insulated with blown-in rock wool insulation, installed by an insulation 
contractor to provide a nominal $\mathrm{R}-19\left(\mathrm{R}_{\mathrm{SI}^{-}}-3.3\right)$. In six locations, panels were installed atop the rock wool, directly above the heat-flux transducers, in such a way that the space between trusses was covered with a layer of superinsulation. The heat flux data obtained from the transducers and the attic-air to interior-air temperature difference were used with a linear regression technique to calculate the thermal conductance and resistance using Eq. (4). These linear regression R-values will be referred to as the "Field" values. For two of the panels, the data showed a wide spread instead of the expected linear distribution, leading to very low regression coefficients, and these values were therefore not reported.

A "laboratory" R-value for the vacuum insulation panel/ rock wool combination was obtained from the data in Table 22 and Eq. (26) which is a correlation for the $\mathrm{k}_{\mathrm{a}}$ of the rock wool density at a mean temperature of $75^{\circ} \mathrm{F}\left(24^{\circ} \mathrm{C}\right)$. The density of the loosefill rock wool insulation was determined from insulation thickness and weight measurements using a circular "cookie-cutter" device 12.45 in. $(0.32 \mathrm{~m})$ in diameter to define a volume of insulation. The average density of the loose-fill rock wool was determined to be $1.47 \mathrm{lb} / \mathrm{ft}^{3}\left(23.5 \mathrm{~kg} / \mathrm{m}^{3}\right)$. The average depth of loose-fill insulation above the vacuum insulation panels was determined to be $7.0 \mathrm{in} .(0.18 \mathrm{~m})$ for the region near the edge of the roof cavity (locations 1,3,5 in Fig. 5) and $8.1 \mathrm{in.}(0.21 \mathrm{~m})$ away from the edge of the roof cavity (locations 2,4,6 in Fig. 5). These data provide for a calculation of R-18.8 (Rm-3.2) for the edge region and R-21.7 (Rm-3.8) for the central region. Table 23 summarizes the results for the vacuum insulation panels.

The Lab-R values are based on $75^{\circ} \mathrm{F}\left(24^{\circ} \mathrm{C}\right)$ measurements while the Field-R values may have been a few degrees warmer. Since thermal resistance decreases with increasing temperature, the Lab-R are overestimates. Two of the test panels, 1 and 5, deviated significantly from the Lab-R or predicted value. This suggested a failure on the part of vacuum insulation panels 1 and 5. Panel Number 5 is "soft" to the touch indicating a loss of internal vacuum and significant loss of R-value. The panels were retested in the laboratory after they were removed from the roof test facility and those two panels had indeed failed (see Table 22). The other two panels, for which the field data was not available, tested very near their pre-installation values. 
Table 23. Effective R-Values for a Combination of Vacuum Insulation Panels and Loose-Fill Rock Wool Insulation

\begin{tabular}{|l|l|l|l|}
\hline Location & \multicolumn{1}{|c|}{$\begin{array}{c}\text { Field R } \\
\left(\mathrm{ft}^{2} \bullet \mathrm{h} \bullet{ }^{\circ} \mathrm{F} / \mathrm{Btu}\right)\end{array}$} & $\begin{array}{c}\text { Lab R } \\
\left(\mathrm{ft}^{2} \bullet \mathrm{h} \bullet{ }^{\circ} \mathrm{F} / \mathrm{Btu}\right)\end{array}$ & Field/Lab \\
\hline 1 - Edge & 12.5 & 34.1 & 0.37 \\
\hline 3 - Edge & 28.3 & 31.8 & 0.89 \\
\hline 5 - Edge & 8.5 & 33.1 & 0.26 \\
\hline 2 - Central & Not reported & 36.8 & \\
\hline $4-$ Central & Not reported & 36.9 & \\
\hline 6 - Central & 32.4 & 37.1 & 0.87 \\
\hline
\end{tabular}

\section{INVENTIONS}

No inventions were made as part of this CRADA.

\section{COMMERCIALIZATION POSSIBILITIES}

Clayton Homes now uses ceiling insulation methods recommended by this project to reduce energy loss through ceiling joists.

\section{PLANS FOR FUTURE COLLABORATIONS}

There are no definite plans for future collaborations.

\section{CONCLUSIONS}

Two single-wide manufactured home units have been studied over a period of four years. The units were instrumented to obtain heat flow data, temperatures, and electric power use. One of the single-wide homes contained the standard insulation package provided by the manufacturer while the second single-wide unit contained an upgraded insulation package. The roof test facility was constructed to test specialized roof cavity insulation like evacuated panel insulation. The field-site data collection was supplemented by careful laboratory characterization of the insulations used in the roof cavities. Important results from the project are summarized below. 
- The installed roof cavity insulation performed at, or better than, the expected level of R-value. Time-average $\mathrm{R}$-values were $\mathrm{R}-17\left(\mathrm{R}_{\mathrm{SI}}-3.0\right)$ for the unit with nominal $\mathrm{R}-14\left(\mathrm{R}_{\mathrm{SI}}-2.4\right)$ and $\mathrm{R}-23.5\left(\mathrm{R}_{\mathrm{SI}}-4.1\right)$ for the unit with nominal $\mathrm{R}-21\left(\mathrm{R}_{\mathrm{SI}}-3.6\right)$. These R-values are for the floor of the roof cavity.

- A significant energy savings would result from increasing the thermal resistance in the region occupied by trusses. These energy savings vary according to the climate and can be accomplished by covering the trusses with insulation.

- The total amount of air infiltration energy losses was nearly equal for both units. This heat loss or gain due to air infiltration accounted for $32 \%$ of the heat pump power use in the case of the standard unit and $41 \%$ in the case of the upgraded unit.

- The standard unit used 30\% more electric power for heating and cooling than the upgraded unit. This difference is too large to be accounted for solely by differences in roof cavity insulation. Differences between construction details and heating/cooling equipment are other factors.

- The application of a radiation control coating with a solar reflectance of 0.86 resulted in significant decreases in the summer-time attic temperatures.

- Intact vacuum insulation panels delivered predicted (laboratory measured) Rvalues when installed in the roof cavity. However, two out of six panels were damaged either during transport or installation, emphasizing the importance of careful handling of this type of insulation.

- $\quad$ Computer simulations showed an average savings of $1382 \mathrm{kWh} /$ year attributable to a radiation control roof coating for single-wide units with roof cavity insulation at the R-14 $\left(\mathrm{R}_{\mathrm{SI}}-2.4\right)$ level for the nine cities considered. As expected, the electric power savings were greatest in the South. There was a wintertime electric power penalty predicted in every city included in the analysis.

\section{ACKNOWLEDGMENTS}

Funding for this CRADA was provided by Clayton Homes Inc, Tennessee Technological University, and the US Department of Energy, Office of Building Technology, State and Community Programs, under contract number DE-AC0596OR22464 with the Oak Ridge National Laboratory, managed by Lockheed Martin Energy Research Corportation. A large number of people have contributed to the progress and completion of this manufactured home project. The authors acknowledge DOE managers Bill Stewart (now retired), Fred Singleton, and Robert Brown for their help with funding and management of the program. Tom Kollie at the Oak Ridge 
National Laboratory (now retired) was instrumental in initiating the project. Ron Graves of the Oak Ridge National Laboratory (now retired) supervised the instrumentation of the full-size units. Fred Weaver (ORNL) made numerous heat flow measurements and Ken Childs and Mark Wendel(ORNL) provided valuable computational fluid dynamics analysis. J. R. Booth, Don Williams, and Perry Melton at Tennessee Tech contributed time and expertise in designing, building, and gathering data. Sharon Robinson of the Department of Chemical Engineering at Tennessee Tech helped with report preparation and Suzanne Henry of the Center for Manufacturing Research at Tennessee Tech managed the financial aspects of the project. The authors are grateful to all of these individuals.

\section{REFERENCES}

1. ASTM C 518, "Standard Test Method for Steady-State Heat Flux Measurements and Thermal Transmission Properties by Means of the Heat Flow Meter Apparatus," 1998 Annual Book of ASTM Standards, Vol. 04.06, American Society for Testing and Materials (1998) pp. 163-174.

2. 1993 ASHRAE Handbook Fundamentals, American Society of Heating, Refrigerating and Air-Conditioning Engineers, Atlanta, GA (1993).

3. D. W. Yarbrough, R. S. Graves, and D. L. McElroy, "Effectiveness of Thermal Insulation in the Attic Spaces of Manufactured Homes," Collected Papers in Heat Transfer 1988, K. J. Yang editor, The American Society of Mechanical Engineers HTD-Vol. 104 (1989) pp. 71-80.

4. CFX-4.2 Solver, AEA Engineering Software, Inc., Bethel Park. PA, December, 1997.

5. ASTM E 779-87 "Standard Test Method for Determining Air Leakage Rate by Fan Pressurization," 1995 Annual Book of ASTM Standards, Vol. 04.07, American Society for Testing and Materials (1995) pp. 658-661.

6. M. H. Sherman and D. T. Grimsrud, "Measurement of Infiltration Using Fan Pressurization and Weather Data, Lawrence Berkley Laboratory Report LBL-10852, University of California, Berkley (1980). 
7. R. W. Anderson, D. W. Yarbrough, R. S. Graves, and R. L. Wendt, "Preliminary Assessment of Radiation Control Coatings for Buildings," Insulation Materials: Testing and Applications, 2nd Volume, ASTM STP 1116, R. S. Graves and D. C. Wysocki, eds., American Society for Testing and Materials (1991) pp. 7-23.

8. Gregory J. Andrews, "A Study of the Energy Efficiency of Two Single-Wide Manufactured Homes," Master of Science Thesis, Tennessee Technological University (1996). 


\section{INTERNAL DISTRIBUTION}

1-10. Therese K. Stovall, Principal Investigator, Bldg. 4508, MS-6092

11. R. A. Bradley, Bldg. 4500S, MS 6161

12. A. J. Luffman, Bldg. 5002, MS-6416

13. C. A. Valentine, Bldg. 701SCA, MS-8242

14. Laboratory Records - RC, Bldg. 4500-N, MS-6285

15-16. Laboratory Records, Bldg. 4500-N, MS-6285

\section{EXTERNAL DISTRIBUTION}

17. Arun Vohra, Department of Energy, EE-41, 1000 Independence Ave., S. W., Washington DC 20585

18. P. L. Gorman, Department of Energy, Oak Ridge Operations Office, Post Office Box 2008, Oak Ridge, Tennessee 37831-6269

19-28. Rick Boyd, Clayton Homes, 5000 Clayton Road, Maryville TN 37804

29-33. Gregory J. Andrews, 9 Pamela Court, Appleton, WI 54915

34-38. David W Yarbrough, Tennessee Technological University, Department of Chemical Engineering, Prescott Hall, Room 214, Stadium Drive, Cookeville TN 38505

39. Dr. T.S. Lundy, Tennessee Technological University, Center for Manufacturing Research, Cookeville, TN 38505

40-41. DOE, Office of Scientific and Technical Information, Office of Information Service, P.O. Box 62, Oak Ridge, TN 37831 